\title{
A review of recent progress (2002-2012) on the biological activities of pyrazoles
}

\author{
Ruth Pérez-Fernández,* Pilar Goya, and José Elguero \\ Instituto de Química Médica, CSIC, Juan de la Cierva, 3, E-28006 Madrid, Spain \\ E-mail: rperezf@iqm.csic.es
}

Dedicated to Professor Rosa M. Claramunt on the occasion of her $65^{\text {th }}$ anniversary

DOI: http://dx.doi.org/10.3998/ark.5550190.p008.131

\begin{abstract}
In this review, we report the structures of 243 pyrazoles with their corresponding biological activities. All of them are represented around the common structure of the pyrazole ring even in those cases where the heterocycle is only a minor part of the molecule. The classification we have used is based on chemical structure considerations and not in terms of the therapeutic area which is the more common approach. Some general conclusions have been drawn linking structures with activities.
\end{abstract}

Keywords: Pyrazoles, pyrazolones, pyrazolines, medicinal chemistry ·

\section{Table of Contents}

1. Introduction

2. Classification criteria for selecting pyrazoles according to their chemical structure

3. Heterocycles

3.1 N-substituted compounds

3.2 C-substituted compounds

3.2.1 Directly linked

3.2.2 With a spacer

4. Amides

4.1 N-substituted compounds (Pz-CO-NH-R)

4.1.1 Directly linked

4.1.2 With a spacer

4.2 C-substituted compounds

4.2.1 Pz-CO-NH-R

4.2.2 R-CO-NH-Pz 
4.3 Hydrazides

4.4 Ureas

5. Esters

6. Carboxylic acids

7. Carbonyl compounds (Pz-CO-R)

$7.1 \mathrm{~N}$-substituted compounds

7.2 C-substituted compounds

8. Amines

8.1 Directly linked

8.2 With a spacer

9. Alcohols and ethers

9.1 Directly linked

9.2 With a spacer

9.3 With a N-O bond

10. Thiols and thioethers

11. Aromatic substituents

$11.1 N$-substituted compounds

11.1.1 Directly linked

11.1.2 With a spacer

11.2 C-substituted compounds

12. Aliphatic substituents

13. Non aromatic compounds

13.1 Pyrazolones

13.2 Pyrazolines

14. Fluoro derivatives $\left(\mathrm{F}, \mathrm{CF}_{3}\right)$

\section{Introduction}

There are two ways to classify a family of compounds with biological properties: either based on their pharmacological activities (CNS, cardiovascular, inflammation, etc...) or on their chemical structure. Neither way avoids the problem of things belonging to two sections: very similar structures having two different activities, or compounds with very different structures having similar activities.

In 2002 we published a review entitled "Pyrazoles as drugs: facts and fantasies"1 which was written using the more traditional classification based on biological activity. Eleven years later, we feel the need to update it using the second approach. Thus, in the present review we have grouped the pyrazoles according to their chemical features and not by therapeutic areas as it is done in Annual Reports in Medicinal Chemistry (Annu. Rep. Med. Chem. abbreviated as ARMC). These reports have been used mainly, but not exclusively, as our source of information. 


\section{Classification criteria for selecting pyrazoles according to their chemical structure}

In the present review we have used several criteria for selecting the compounds that we have included and excluded. Thus, we have excluded fused pyrazoles, like indazoles and pyrazoloazines, although this last group contains very relevant drugs like Sildenafil (a pyrazolo[4,3- $d$ ]pyrimidin-7-one). We have considered reduced indazoles (mainly 4,5,6,7tetrahydroindazoles, as tetramethylene pyrazoles) as well as other derivatives like their aza derivatives, dihydroindazoles, etc... (i.e. we have not used their systematic names but the pyrazole ring as criteria of selection).

We have considered situations where the functional group is separated from the pyrazole ring by a methylene because in amino acids the functional groups $\mathrm{NH}_{2}$ and $\mathrm{CO}_{2} \mathrm{H}$ are separated by a $\mathrm{CHR}$. We have also included the cases where $\mathrm{CH}=\mathrm{CH}$ or $\mathrm{C} \equiv \mathrm{C}$ are spacers. All other cases, where the functional group is far from the pyrazole ring, have been classified taking into account the closest atoms.

This leads to the contents list at the beginning of this review.

When there are two or more functional groups, which is often the case, the product will be classified according to the group which appears first in the Table except for Sections 13 and 14. The last section refers to compounds bearing fluorinated substituents like $\mathrm{F}, \mathrm{CF}_{3}, \mathrm{CH}_{2} \mathrm{~F}, \mathrm{C}_{6} \mathrm{~F}_{5}$ and $\mathrm{C}_{6} \mathrm{~F}_{4}$ directly attached to the pyrazole ring.

Within each group, the therapeutic fields will appear in the following order: Central Nervous System (CNS), pharmacodynamics, metabolic diseases and chemotherapeutic agents. ${ }^{1}$

Concerning references we have quoted the journals provided in ARMC. In cases of patents or communications to symposia we will refer to the corresponding $A R M C$ volume, where the original citation can be found.

Tautomeric NH-pyrazoles are represented in a form that appears to us as the most probable, ${ }^{2,3}$ but that should not be considered as definitive, to avoid repetition of the errors related to the pair of bases in the determination of the structure of DNA. ${ }^{4,5}$

\section{Heterocycles}

This group includes many compounds but it is the frailest because it is arbitrary to define the pyrazole as the main group and the heterocycle as a substituent, or the other way around.

\section{1 $N$-substituted compounds}

The structures of some pyrazoles belonging to this section are reported in Scheme 1. Compound $\mathbf{2}$ is described under heading 3.2.1 and compounds 6-9 under heading 6. Compound $\mathbf{1}$ has antidepressive and anti-anxiety properties. ${ }^{6}$ The bipyridyl derivatives $\mathbf{2}$ (with different $\mathrm{R}^{1}$ and $\mathrm{R}^{2}$ 
substituents) are antagonists of the opioid receptor-like 1 (ORL1). ${ }^{7}$ ORL1 was discovered in 1994, based on its high degree of amino acid sequence homology to the classical opioid receptors. Despite this homology, the classical opioids did not bind to this receptor with significant affinity. Subsequently, its endogenous agonist, a 17-amino acid peptide known as Nociceptin or Orphanin FQ (NC/OFQ), was identified. A number of reports have since demonstrated the possible involvement of the NC/OFQ-ORL1 system in pain regulation, morphine tolerance, learning and memory, food intake, anxiety, the cardiovascular system and locomotor activity. The triazacarbazole derivative $\mathbf{3}$ has been described as a BACE ( $\beta$-secretase) inhibitor useful for the treatment of Alzheimer's disease. ${ }^{8}$

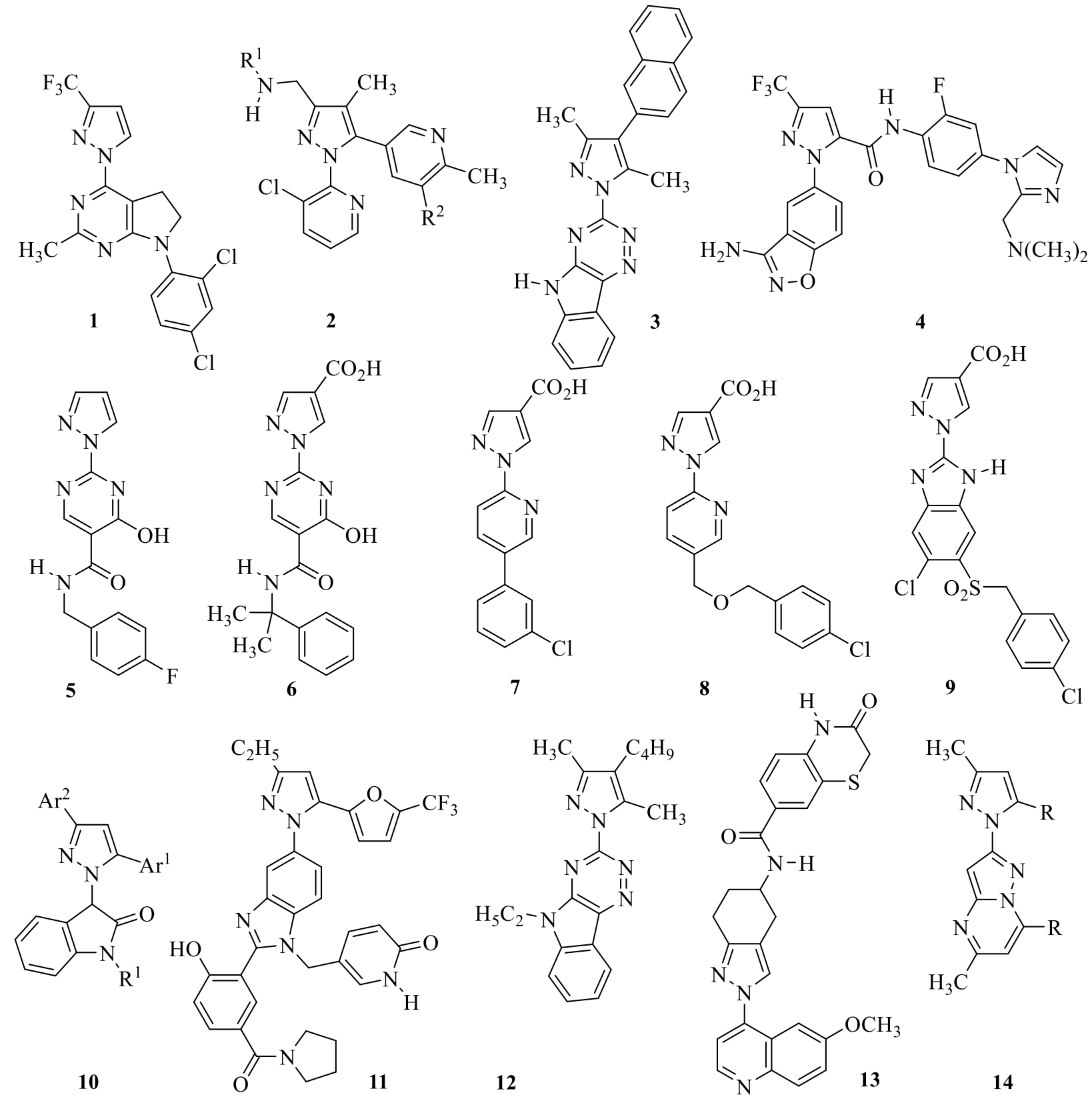

Scheme 1. N-Heteroarylpyrazoles. 
Razaxaban 4 (DPC906) is a factor Xa inhibitor useful as an anticoagulant. ${ }^{9}$ Compound 5 and (mainly) the 4-carboxylic acid derivatives 6-9 are inhibitors of the HIF (hypoxia inducible factor) studied as possible treatments of anemia. ${ }^{10-13}$

The indolin-2-one derivatives 10 (15 compounds) have been reported as anti-tumor agents. ${ }^{14}$ The complex structure 11 with five different heterocycles showed anti HIV-1 properties due to the fact that it is a CANTD (Capsid Assembly N-terminal) inhibitor. ${ }^{15}$ Structurally related to $\mathbf{3}$, compound $\mathbf{1 2}$ is an inhibitor of the $\mathrm{HCV}$ (hepatitis $\mathrm{C}$ virus) NS4B replication factor. ${ }^{16}$ Compound 13 was shown to inhibit DNA gyrase and topoisomerase IV in $S$. aureus, $S$. pneumoniae and $E$. coli being an interesting anti-bacterial agent. ${ }^{17} \mathrm{~A}$ series of simple pyrazolo[1,5- $a$ ]pyrimidines $\mathbf{1 4}\left(\mathrm{R}=\mathrm{CH}_{3}\right.$, aryl, thienyl) have been evaluated as anti-bacterial agents. $^{18}$

It is difficult to reach any conclusion concerning these compounds because it is not easy to differentiate the relative influence of both heterocycles. The simplest answer is to consider that the heterocycle bearing more substituents is the core structure and the one with less, the peripheral "decoration".

\section{2 $C$-substituted compounds}

3.2.1 Directly linked. This is one of the most populated sections. The structures are gathered in Schemes 2 and 3 (cancer). Compounds 15-22 have potential CNS applications: two PDE10 (Phosphodiesterase type II) inhibitors, 15 and 16, for schizophrenia; ${ }^{19,20}$ one histamine $\mathrm{H}_{3}$ antagonist 17 (A-688057) for cognitive disorders; ${ }^{21}$ an antipsychotic 18; ${ }^{22}$ a series of labeled compounds $\left({ }^{11} \mathrm{C},{ }^{18} \mathrm{~F}\right) \mathbf{1 9}$ for PET (positron emission tomography) tracers to study phosphodiesterase-10, a useful target in various CNS disorders [with $\mathrm{R}^{1}$ an azine and $\mathrm{R}^{2}$ a $\left(\mathrm{CH}_{2}\right)_{\mathrm{n}} \mathrm{CH}_{2}{ }^{18} \mathrm{~F}$ chain]; ${ }^{.23-26}$ compound 20, an inhibitor of c-Jun $N$-terminal kinase $\left(\mathrm{JNK}_{3}\right)$ also interesting for the treatment of CNS disorders. ${ }^{27}$ Two compounds $\mathbf{2 1}$ and $\mathbf{2 2}$ were prepared for the treatment of Parkinson's disease which are positive allosteric modulators of mGlu4 receptor (metabotropic glutamate receptors). ${ }^{28}$

Anti-inflammatory derivatives $\mathbf{2 3}$ [inhibitor of the ERK (extracellular signal-regulated protein kinase) pathway] ${ }^{29}$ and $\mathbf{2 4}$ (inhibitor of the tyrosine kinase receptor) ${ }^{30}$ have been reported. Based on the structure of Rimonabant (99, Section 4.3) a series of $N$-arylpyrazoles and $N$-heteroarylpyrazoles were prepared and studied as anti-obesity agents: 25 and 26 (CB1 antagonists); ${ }^{31}$ compound 27 (CRX 000143) has a different mechanism of action being a PPAR $\gamma$ (peroxisome proliferator-activated receptor) modulator reducing adipogenicity; 32 compound 28 acts on the NHR LXR receptors (Nuclear hormone receptor; Liver X receptor) interfering with the lipid metabolism (we have preferred to classify this compound here instead of in Section 3.a, together with other anti-obesity compounds); ${ }^{33}$ finally, trimethylenepyrazole 29 with a tetrazole substituent as a bioisoster of the carboxylic acid (Section 6) is a GPR109a (G-protein-coupled receptor for niacin) agonist that acts on adipocytes. ${ }^{34}$ An insulin sensitizer $\mathbf{3 0}$ for the treatment of 
Type 2 diabetes has been reported. ${ }^{35-37}$ Amongst these compounds, the most interesting is 29 (MK-0354) which has been the subject of many studies and structural modifications. ${ }^{38-40}$

A compound for the treatment of ischemic stroke, 31 (a potent pan-JNK inhibitor) ${ }^{41}$ and an inhibitor of coagulation to treat thromboembolic disorders 32 (inhibitor of factors IXa and XIa) ${ }^{42}$ have been reported. Compound $\mathbf{3 3}$ that increases testosterone levels in male rats is a LHR (Gonadotropin luteinizing hormone) agonist. ${ }^{43}$ For pulmonary diseases like asthma, compound 34 (MRE 2029-F20) an $\mathrm{A}_{2 \mathrm{~B}}$ adenosine receptor antagonist ${ }^{44}$ was studied. Derivative 35, a MR (Mineralocorticoid receptor) antagonist has been evaluated to treat hypertension. ${ }^{45}$

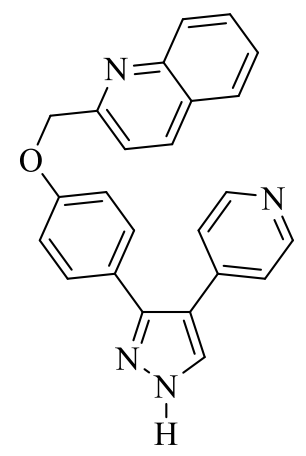

15

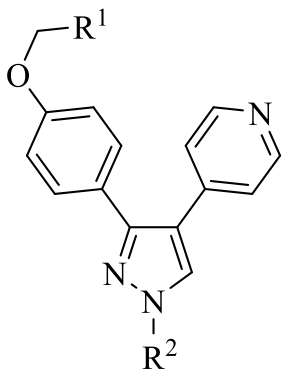

19

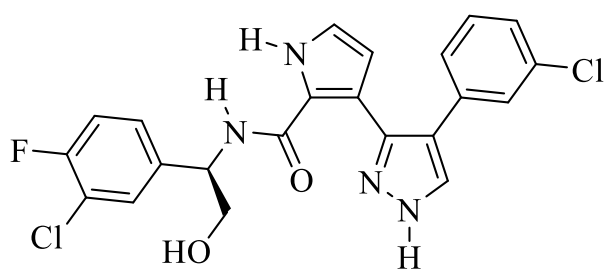

23<smiles>C/C=C\C=C/c1nn(-c2ccccc2Cl)c(-c2ccc(Cl)cc2)c1C</smiles>

25

16

20
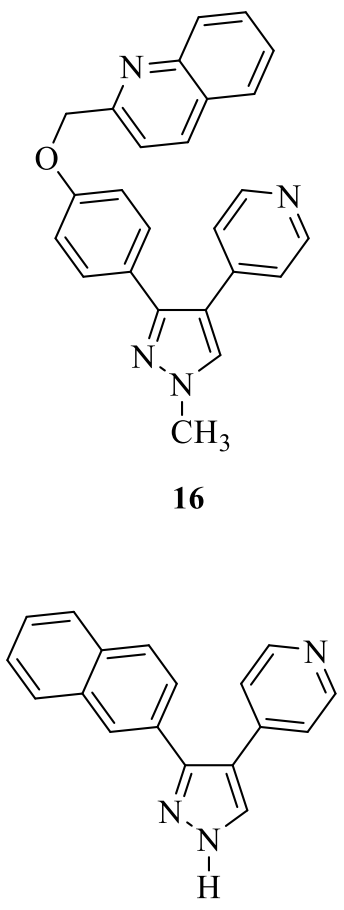<smiles>CN(C)Cc1cccc(Cl)n1</smiles><smiles>CCN(CC)C/N=C/Cl</smiles><smiles>Cc1c(C2CNCCO2)nn(-c2ccccc2Cl)c1-c1ccc(Cl)cc1</smiles><smiles>COc1ccc(C(=O)/C=C/c2cn(-c3ccccc3)nc2-c2cccnc2)cc1</smiles> 
<smiles>N#Cc1c(C(F)(F)F)cc(-c2cnn(-c3cccc(C(F)(F)F)n3)c2)n(-c2ccc(F)cc2F)c1=O</smiles>

28<smiles>c1n[nH]nc1-c1n[nH]c2c1CCC2</smiles>

29

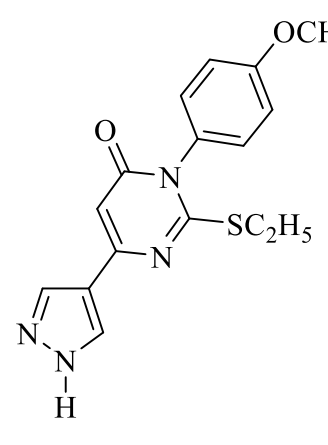

30<smiles>CCCCc1cncc(-c2c(-c3cccc(F)c3)nn3c2[C@H](Cn2cccc2)CC3)n1</smiles>

31<smiles>N=C(N)c1ccc2[nH]c(-c3n[nH]c(-c4ccccc4)c3O)nc2c1</smiles>

32

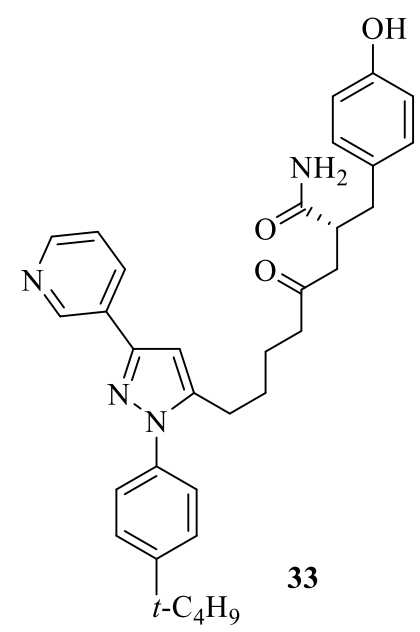<smiles>CCCn1c(=O)c2[nH]c(-c3cc(OCC(=O)Nc4ccc5c(c4)OCO5)nn3C)nc2n(CCC)c1=O</smiles><smiles>Cc1nn(Cc2cccnc2)c(-c2ccc(F)cc2)c1-c1ccc2c(c1)NC(=O)CO2</smiles>

35

Scheme 2. $C$-heteroaryl pyrazoles.

The most important activity of $C$-arylpyrazoles is as anti-tumor agents (Scheme 3 ) with two compounds in the market, Ruxolitinib $37^{46}$ and Crizotinib 38. ${ }^{47}$ Quinoxaline derivatives 36, inhibitors of PI3K (Phophatidyl-inositol-3-kinases) are tumor growth inhibitors. ${ }^{48}$ Many papers have dealt with Ruxolitinib, a Janus kinase 2 (JK2) inhibitor for the treatment of MPN (myeloproliferative neoplasm) $)^{49,50}$ and Crizotinib (PF-02341066) [a dual cMet/ALK inhibitor (protooncogen/anaplastic lymphoma kinase)] for the treatment of NSCLC (non-small cell lung carcinoma). ${ }^{51,52}$ Compound 39 (PF-00477736) is an inhibitor of Check point kinase 1 (CHK1). ${ }^{53}$ Pyrazolo[1,5-a]pyrimidine derivatives 40 and $\mathbf{4 1}$ (SCH900776) are CHK1 inhibitors that have been studied for preventing the progression of cancer. ${ }^{54,55}$ Compound 42 (A-83-01) has been developed to prevent metastasis being an ALK-5 inhibitor (activin receptor-like kinase 5). ${ }^{56} \mathrm{~A}$ large number of pyrazole derivatives bearing a $3 H$-imidazo[4,5-b]pyridine substituent have been studied, $\mathbf{4 3}$ being one of the most interesting. They are dual FLT3 (Fms-like tyrosine)/Aurora kinase inhibitors that are orally active against acute myeloid leukemia. ${ }^{57}$ 
<smiles></smiles>

37 (Ruxolitinib)

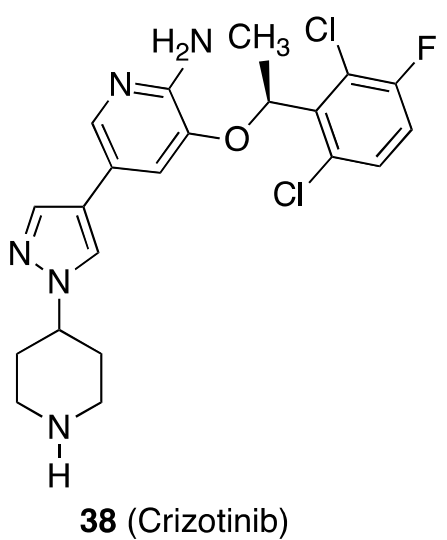<smiles>Cn1cc(-c2[nH]c3cc(NC(=O)[C@@H](N)C4CCCCC4)cc4c3c2C=NNC4=O)cn1</smiles><smiles>Cn1cc(-c2cnn3c(N)cc(C4CCCNC4)nc23)cn1</smiles>

40<smiles>Cn1cc(-c2cnn3c(N)c(Br)c(C4CNCCS4)nc23)cn1</smiles>

41
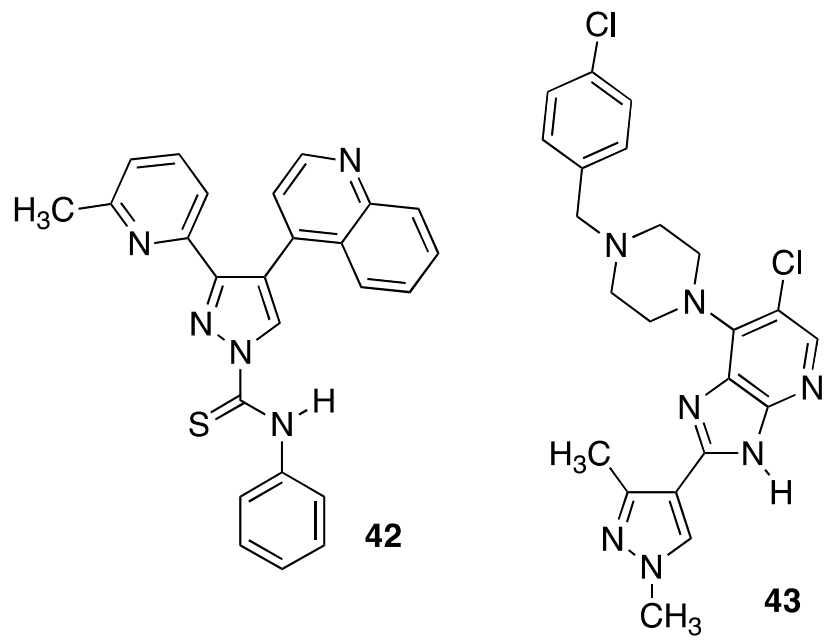

Scheme 3. $C$-heteroarylpyrazoles with anti-tumor properties.

From Section 3.2.1 it appears that often the heterocyclic substituent is on $\mathrm{C} 4$ and there are many $\mathrm{NH}$ and $\mathrm{N}-\mathrm{CH}_{3}$ examples except for the anti-obesity compounds that are, in general, $\mathrm{N}$-aryl derivatives.

3.2.2 With a spacer. Only four compounds belong to this section (Scheme 4) and three of them are clearly 6-methylidene penems, the pyrazole being a substituent. They are inhibitors of $\beta$ lactamases. Compounds $\mathbf{4 4}$ and $\mathbf{4 5}$ are potent inhibitors, particularly $\mathbf{4 4}$. The corresponding $E$ isomer of $\mathbf{4 5}$ was found to be 640 times less active against TEM-1 and AmpC genes than the $Z .^{58}$ Penems $\mathbf{4 5}$ and $\mathbf{4 6}$ are also potent inhibitors of OXA-1 (class D) $\beta$-lactamase. ${ }^{59}$

Compound 47 was reported as an inhibitor of LP-PLA 2 (Lipoprotein/Phospholipase), studied for the treatment of atherosclerosis. ${ }^{60,61}$ 
<smiles></smiles>

44

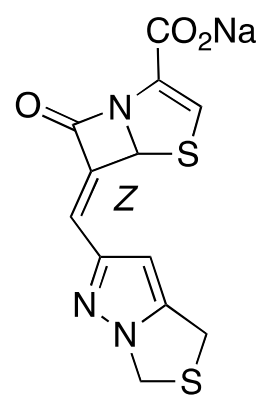

45<smiles></smiles>

46

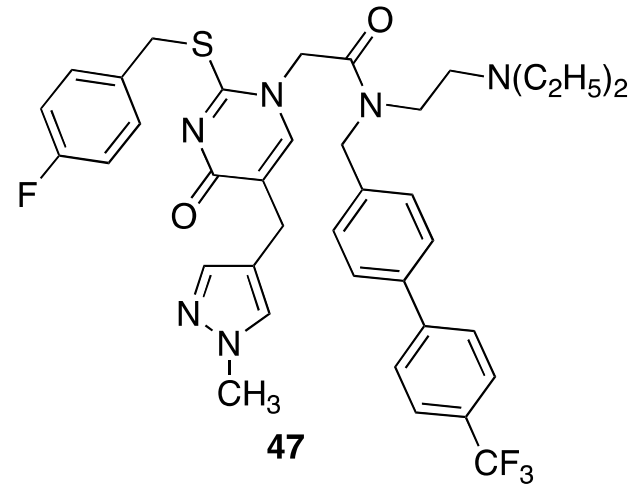

Scheme 4. $C$-heteroarylpyrazoles with a spacer.

\section{Amides}

\subsection{N-substituted compounds (Pz-CO-NH-R)}

4.1.1 Directly linked. Compound 48 (Scheme 5) was described as a sodium channel blocker that was studied for the treatment of neuropathic pain. ${ }^{62}$ (Note that compound $\mathbf{4 2}$ of Section 3.2.1 is an $N$-thioamide).

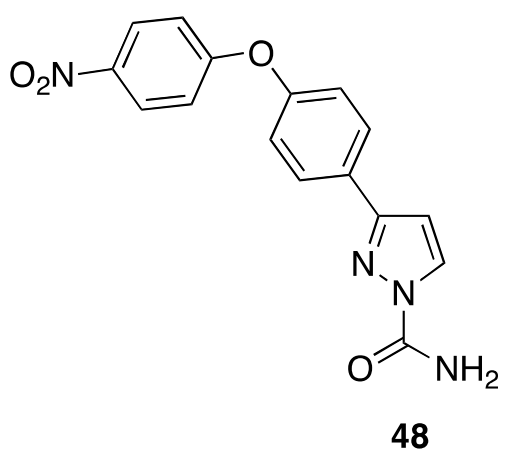

48

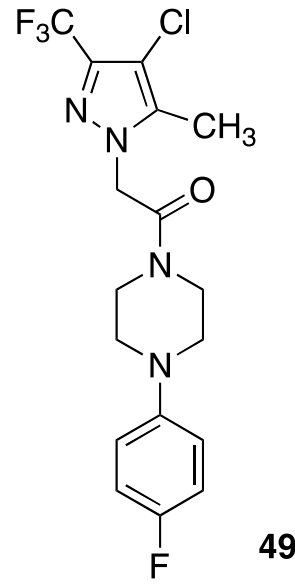

49<smiles>COc1cc(N2CCN(C(=O)Cn3nc(C(F)(F)F)c(Cl)c3C)CC2)c(Cl)cc1Cl</smiles>

Scheme 5. $N$-substituted amides.

4.1.2 With a spacer. Compounds 49 and $\mathbf{5 0}$ behave as CCR1 (Chemokine receptor-1) antagonists with anti-inflammatory properties. ${ }^{63}$ 


\section{2. $C$-substituted compounds}

4.2.1. Pz-CO-NH-R. This Section is the one containing the most examples.

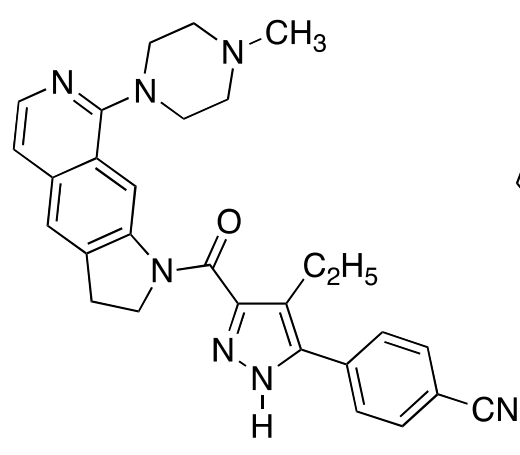

51

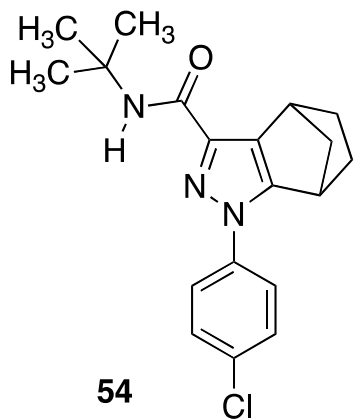

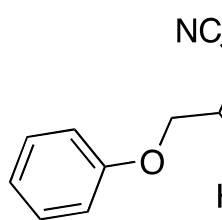

$\mathrm{NC}$<smiles>CC(=N)NC(=O)c1cc(C(F)(F)F)n(-c2ccc(Cl)cc2)n1</smiles>

52

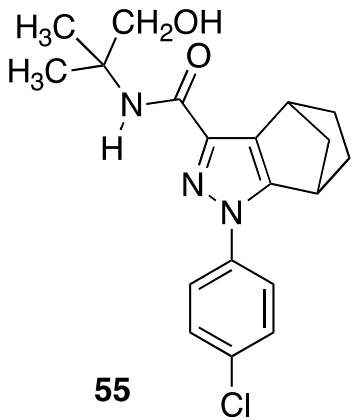

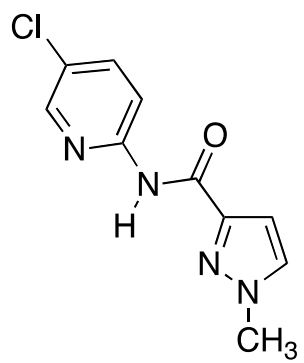

56
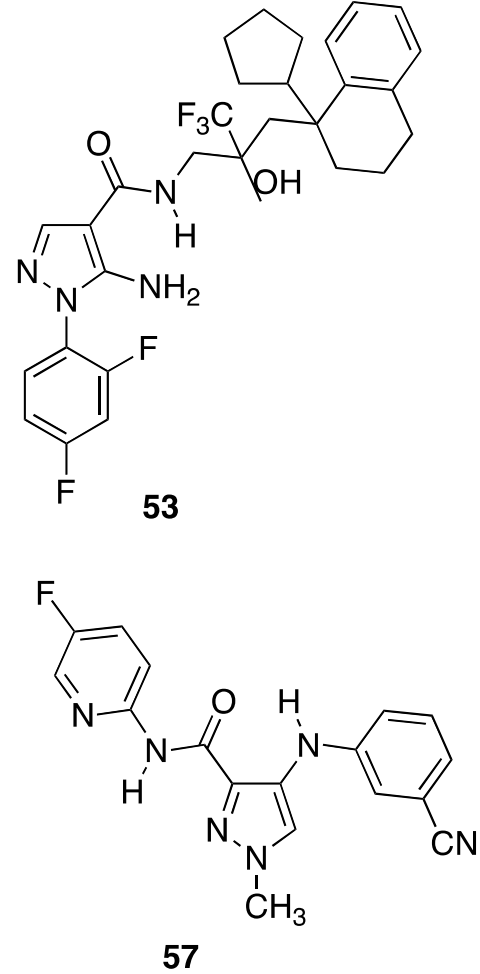

Scheme 6. CNS, pain, inflammation, Parkinson's disease.

Compound 51 showed in vivo 5-HT1B (5-hydroxytryptamine receptor 1B) antagonism, which makes it interesting as a potential antidepressant drug. ${ }^{64}$ Compound $\mathbf{5 2}$ is a blocker of the voltage-gated sodium channel $\mathrm{Na}_{\mathrm{v}} 1.8$ and as such, can have application for the treatment of neuropathic pain. ${ }^{65}$ Within a series of cannabinoid CB2 agonists, useful for inflammatory and neuropathic pain, pyrazoles 54 and 55 have been disclosed, the latter showing improved pharmacokinetic properties. ${ }^{66}$ Methylpyrazole 56 is an activator of the potassium channel $\mathrm{K}_{\mathrm{v}} 7$ involved in the regulation of heartbeat and neuronal activity. ${ }^{67}$ Compound $\mathbf{5 7}$ has been reported as a negative allosteric modulator of mGluR5. These mGluR5 NAMs are promising agents for CNS diseases such as Parkinson's and also for major depressive disorders. ${ }^{68}$

Related to Razaxaban 4, a series of pyrazole carboxamides such as compounds 58-62 have been described as anticoagulant agents acting through inhibition of factor Xa. Among them, the trifluoromethyl derivative $\mathbf{6 2}$ showed an overall enhancement of pharmacokinetic properties in rat. ${ }^{69,70}$ High throughput screening (HTS) of existing libraries was used to identify novel dual inhibitors of factor Xa and Factor IXa, another interesting target in the coagulation cascade. An example of an optimized inhibitor is benzimidazole derivative $63 .^{71}$ 
Apixaban 64 is a second-generation pyrazole-based factor $\mathrm{Xa}$ inhibitor which is a modification of the previous Razaxaban by constraining the pyrazole amide to a bicyclic pyrazolopyridinone. It was approved in Europe in 2011 under the trade name of Eliquis for prevention of venous thromboembolic events in patients after hip or knee replacement surgery. ${ }^{72}$ Other pyrazole based inhibitors of factor Xa are derivatives 65 and $\mathbf{6 6}$, both showing $K_{i}$ in the nanomolar range. The first one, $\mathbf{6 5}$ was derived from Razaxaban replacing the amide linker by a ketone moiety, whereas $\mathbf{6 6}$ had a bicyclic core similar to that of Apixaban. ${ }^{73,74}$ In the course of the search of Razaxaban, many pyrazole compounds have been synthesized and evaluated as Xa inhibitors, one of the first important derivatives was compound 67 (SN429) with picomolar affinity. ${ }^{75}$

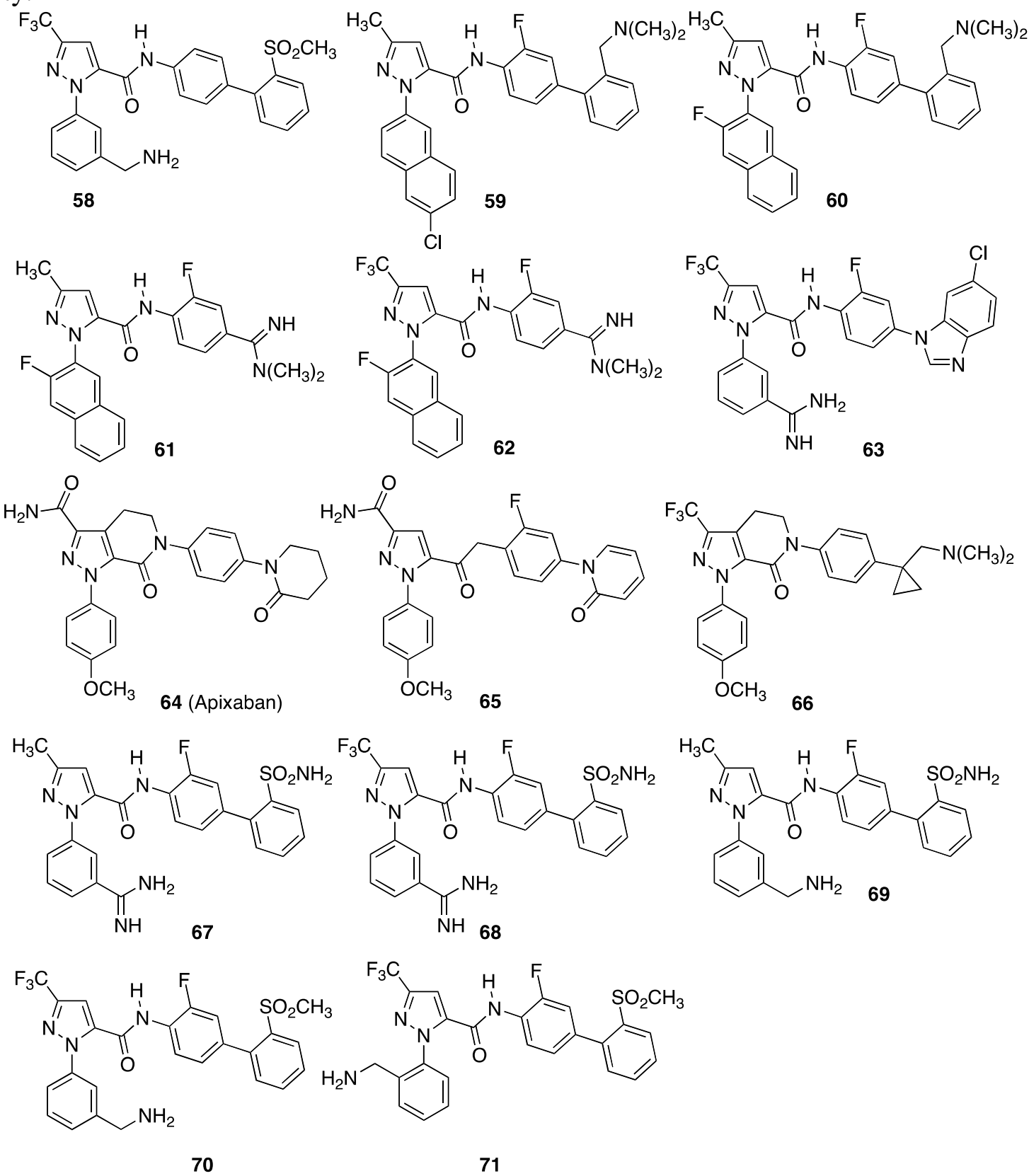


<smiles>Nc1noc2ccc(-n3nc(C(F)(F)F)cc3C(=O)Nc3ccc(-c4ccccc4S(N)(=O)=O)cc3F)cc12</smiles>

72<smiles>CNCc1ccccc1-c1ccc(N2CCc3c(C(N)=O)nn(-c4ccc(OC)cc4)c3C2=O)cc1</smiles>

75<smiles>[R]c1nccn1-c1ccc(NC(=O)c2cc(C(F)(F)F)nn2-c2ccc3onc(N)c3c2)c(F)c1</smiles>

73, a, $\mathrm{R}=\mathrm{CH}_{3}$, b, $\mathrm{CH}_{2} \mathrm{NHCH}_{3}$ c, $\mathrm{CH}_{2} \mathrm{~N}\left(\mathrm{CH}_{3}\right)_{2}$

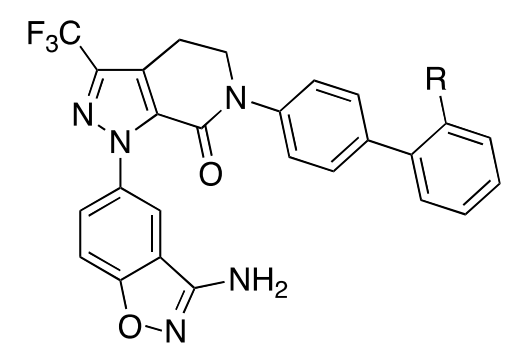

74, a, $\mathrm{R}=\mathrm{SO}_{2} \mathrm{CH}_{3}, \mathbf{b}, \mathrm{CH}_{2} \mathrm{~N}\left(\mathrm{CH}_{3}\right)_{2}$, c, 3-hydroxy-1-pyrrolidine<smiles>[Y7]OCCOCCOc1cc(C(=O)N[C@@H](CCC(=O)O)C(=O)N2CCN(C(=O)O[R])CC2)nn1-c1ccccc1</smiles>

Scheme 7. Platelet anticoagulants.

Replacement of the methyl by a trifluoromethyl group afforded the very potent derivative $\mathbf{6 8}$. Successful substitution of benzamidine by benzylamine as in compounds 69-71 provided the early clinical candidate 70. In order to improve potency and selectivity the aminobenzisoxazole derivatives 72-74 were prepared. Later, and in order to avoid metabolic cleavage of the amide, rigid pyrazole scaffolds, such as dihydropyrazolopyridones 75-76 were studied. ${ }^{76}$

Compound 77 is the only CONHR derivative of Scheme 7 where the amide group is at position 3. It was identified as a high-affinity $\mathrm{P}^{2} \mathrm{Y}_{12}$ (purinoreceptor) antagonist with interesting properties as platelet aggregation inhibitor. ${ }^{77}$

The pyrazole ring has been extensively studied as a structural motif in cannabinoid ligands with potential therapeutic applications in different areas. Concerning CB1 antagonists, cyano pyrazole 78, CP-272,871 has been reported. ${ }^{78}$ Other analogs of Rimonabant include the butyl derivative $\mathbf{8 0}^{79}$ and conformationally constrained analogs such as 79 and 5,5 bicyclic derivatives as 81, the latter showing the higher affinity for the cannabinoid CB1 receptor. ${ }^{80}$

JAK3 is an important target in immunological disorders. In a report dealing with virtual screening to identify JAK3 inhibitors, indazole $\mathbf{8 2}$ was described. Although it had an $\mathrm{IC}_{50}$ of 2.5 it did not represent an improvement over the starting compound. ${ }^{81}$ Pyrazole 83, CH-223191 is a potent antagonist of dioxin-induced aryl hydrocarbon receptor (AhR) in mice, and may be useful for the prevention of TCDD (2,3,7,8-Tetrachlorodibenzo- $p$-dioxin) associated pathology. TCDD is a widespread environmental pollutant with toxic effects such as endocrine disruption, immunotoxicity and liver damage. ${ }^{82,83}$ 
<smiles>COc1ccc(-c2c(C#N)c(C(=O)Nc3ccccc3)nn2-c2ccccc2Cl)cc1</smiles>

78<smiles>O=C1c2nn(-c3ccccc3Cl)c(-c3ccc(Cl)cc3)c2OCCN1CC(F)(F)F</smiles>

79<smiles>CCCCCCCCCc1ccc(-c2c(C(=O)NCc3ccccc3)cnn2-c2cccc(Cl)c2)cc1</smiles>

80

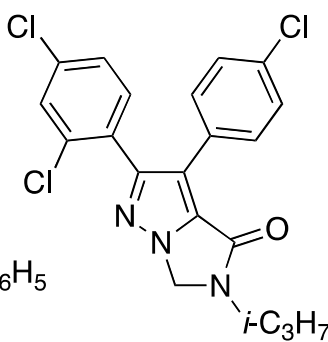

81<smiles>Cc1cc(I)ccc1NC(=O)c1ccnn1C</smiles>

82<smiles>O=C(NCc1cccs1)c1nn2c(c1Cl)N[C@H](c1ccco1)C[C@@H]2C(F)(F)F</smiles>

86

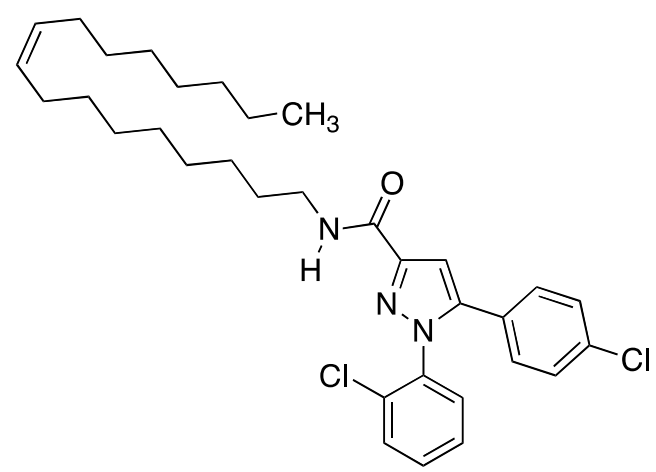

89<smiles>CCOC(=O)C(C)(C)Oc1ccc(NC(=O)c2nn(-c3ccc(Cl)cc3Cl)c(-c3ccc(Cl)cc3)c2C)cc1</smiles>

88, a, $R^{1}=R^{2}=R^{3}=H$

85

87<smiles>Cc1ccccc1N</smiles><smiles>COC</smiles><smiles>c1cnn2ccnc2c1</smiles><smiles>FC(F)(F)C1=CCCC=C1</smiles><smiles>CCCC(C)N(CCOC)C(=O)c1cnn(C)c1C1=Cc2cc(OC)ccc2-c2c(C3CCCCC3)c3ccc(C(=O)NS(=O)O)cc3n2C1</smiles><smiles>CCN1CCN[C@H](C)C1</smiles><smiles>CC</smiles>

$\mathrm{C}_{6} \mathrm{H}_{5} \mathrm{H}_{2} \mathrm{C}^{-}$

84<smiles>Cc1ccc(C)c(NC(=O)c2cc(C)nn2C)c1</smiles>

RLIF<smiles>Cc1cc(C(=O)NF)nn1C</smiles>

b, $\mathrm{R}^{1}=\mathrm{Cl}, \mathrm{R}^{2}=\mathrm{H}, \mathrm{R}^{3}=\mathrm{Cl}$

c, $R^{1}=\mathrm{Cl}, \mathrm{R}^{2}=\mathrm{R}^{3}=\mathrm{H}$

d, $R^{1}=F, R^{2}=R^{3}=H$

e, $\mathrm{R}^{1}=\mathrm{H}, \mathrm{R}^{2}=\mathrm{Cl}, \mathrm{R}^{3}=\mathrm{H}$

Scheme 8. CB1, obesity, autoimmune, antiviral, osteoporosis, antiviral, anticancer activities.

Within the antiviral field, in a patent dealing with of CXCR4 (chemokine receptor type 4) inhibitors, pyrazole 84 has been described with an $\mathrm{IC}_{50}$ of $0.4 \mathrm{nM}$ for HIV replication. CXCR4 is 
a member of the chemokine receptor family, an important target for AIDS. Compounds $\mathbf{8 5}^{84}$ and 86 have been claimed in patents as inhibitors of $\mathrm{HCV}$ replication. ${ }^{85}$

A novel inhibitor of the vascular endothelial growth factor receptor/platelet-derived growth factor receptor (VEGFR/PDGFR) is pyrazole 87 (TAK-593) which showed a long residence time. $^{86}$

In relation to the development of non-ATP-competitive protein kinase inhibitors for oncology, a series of pyrazoles 88a-88e have been reported. Among them, 88c was the most potent in the cyclin-dependent kinase, CDK2/cyclin context. ${ }^{87}$

Fatty acid amide derivatives of pyrazoles, such as $\mathbf{8 9}^{88}$ have been prepared which reduce food intake in vivo. Designed multiple ligands targeting both the CB and the PPAR receptors have been reported. Derivatives of rimonabant linked to fibrates $\mathbf{9 0}^{89}$ have been synthesized and the compounds have shown affinity in the nanomolar range for both types of receptors.

4.2.2 R-CO-NH-Pz. Neuropeptide Y (NPY) is an attractive target for obesity. Aryl pyrazole derivatives 91 and 92 were synthesized and evaluated as NPY Y5 antagonists. The chiral compound (-)-91 showed good binding affinity and inhibited food intake. ${ }^{90}$ Compound $\mathbf{9 3}$ (CDPPB) is a mGluR5 enhancer which reduces amphetamine-induced locomotor activity and so, of potential use for the treatment of schizophrenia. ${ }^{91}$

Phenylpyrazole 94 was discovered in an HTS approach as a dual BcL-2/ BcL-xL inhibitor, proteins of the BcL (B-cell Lymphoma) family which regulates apoptosis. ${ }^{92}$ Dipeptide derivatives $\mathbf{9 5}^{93,94}$ and $\mathbf{9 6}^{95}$ have been disclosed as Cathepsin $\mathrm{K}(\mathrm{Cat} \mathrm{K}$ ) inhibitors potentially useful for the treatment of osteoporosis. They are potent inhibitors but have poor selectivity over off-target cathepsins.

The cannabinoid CB2 receptor is a promising therapeutic target for pain devoid of the psychotropic effects associated to CB1 activation. Arylsulfone $\mathbf{9 7}$ showed good potency and selectivity for the cannabinoid CB2 receptor and had good pharmacokinetic properties. ${ }^{96}$

Pyrazole 98 was disclosed in a patent as a mixed inhibitor of mTOR (mammalian target of rapamycin) and $\mathrm{PI} 3 \mathrm{~K}$ (phosphatidylinositol-3-OH kinase) potentially useful in oncology. ${ }^{97}$ Insulin-Like Growth Factor-1 Receptor (IGF-1R) is an emerging cell signaling pathway currently explored for cancer therapy. In a patent dealing with bicyclic pyrazole inhibitors of IGF-1R, the most potent compound was 99, although with limited activity. ${ }^{98}$ Penicillaminederived analog $\mathbf{1 0 0}$ was designed as a Smac (second mitochondrial activator of caspases) mimetic which may have potential use in cancer therapeutics. ${ }^{99}$

Acetylene derivative 101 belongs to the first generation of NS5A (Nonstructural Protein 5A) inhibitors. Novel compounds targeting NS5A are in clinical development as an approach to treat HCV. ${ }^{100}$ Pyrrolidinopyrazole 102 (PHA-739358) is a potent aurora kinase inhibitor with an antitumor profile. ${ }^{101}$ Compound $\mathbf{1 0 3}$ (PHA-E429) is a PARP (poly [ADP-ribose] polymerase) inhibitor, a promising strategy for cancer treatment. ${ }^{102-104}$

Note that compounds 91 and $\mathbf{9 8}$ belong also to Section 3.2.1. 


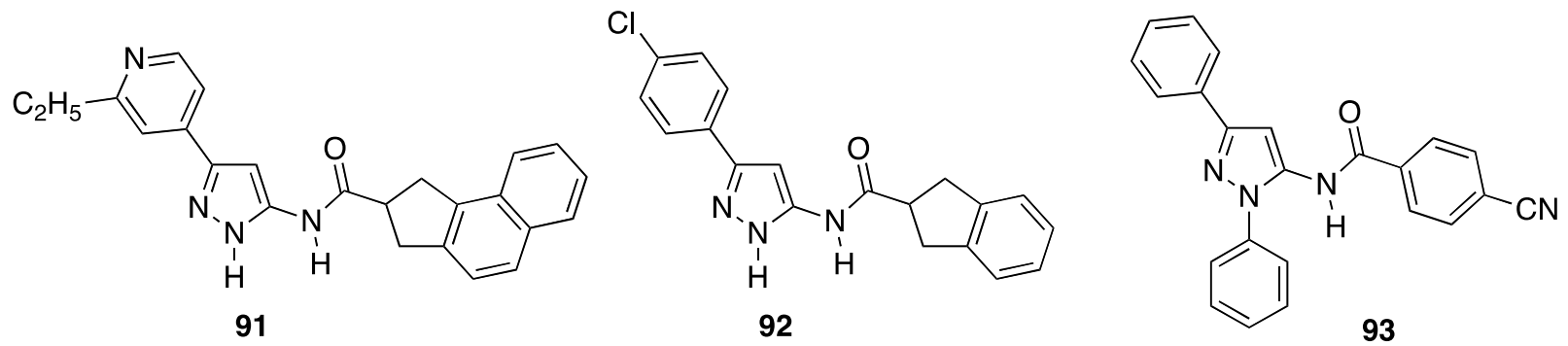<smiles>CCCCNC(=O)c1nn(-c2ccccc2C(=O)N2Cc3ccccc3CC2CN)c(C)c1Cl</smiles>

$t-\mathrm{C}_{4} \mathrm{H}_{9}$<smiles>Cn1nc(S)cc1NC(=O)C(C)(C)Sc1ccc(Cl)cc1</smiles>

97

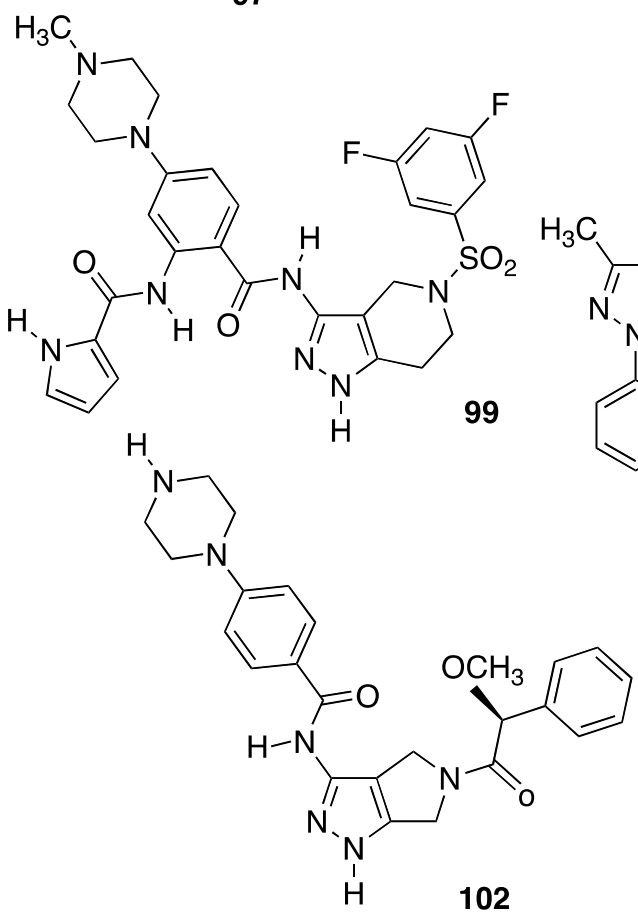

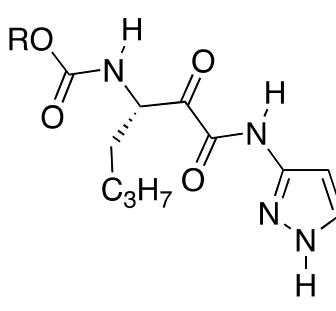

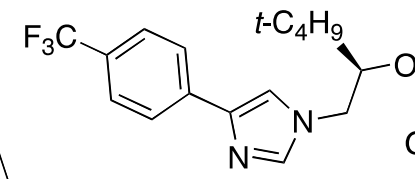<smiles>CCCCCCC(NC(=O)Nc1cc[nH]n1)C(=O)O</smiles>

$\mathrm{H}_{3} \mathrm{C}$<smiles>CC(=O)Nc1cc(-c2cncc(NS(=O)c3c(C)nn(C)c3Cl)c2)[nH]n1</smiles>

98<smiles>CNC(=O)C1N2C(=O)C(N(C)C(=O)C(C)NC)CCC[C@H]2SC1(C)C</smiles>

101<smiles>CC(C(=O)N1Cc2[nH]nc(NC(=O)c3ccc(N4CCN(C)CC4)cc3)c2C1)c1ccccc1</smiles>

Scheme 9. Amides derived from aminopyrazoles. 


\subsection{Hydrazides}

Many diaryl pyrazoles have been synthesized and evaluated as CB1 ligands, the most important being Rimonabant 104, which was launched as anti-obesity agent in Europe in 2006, and withdrawn from the market in 2007 due to side effects.
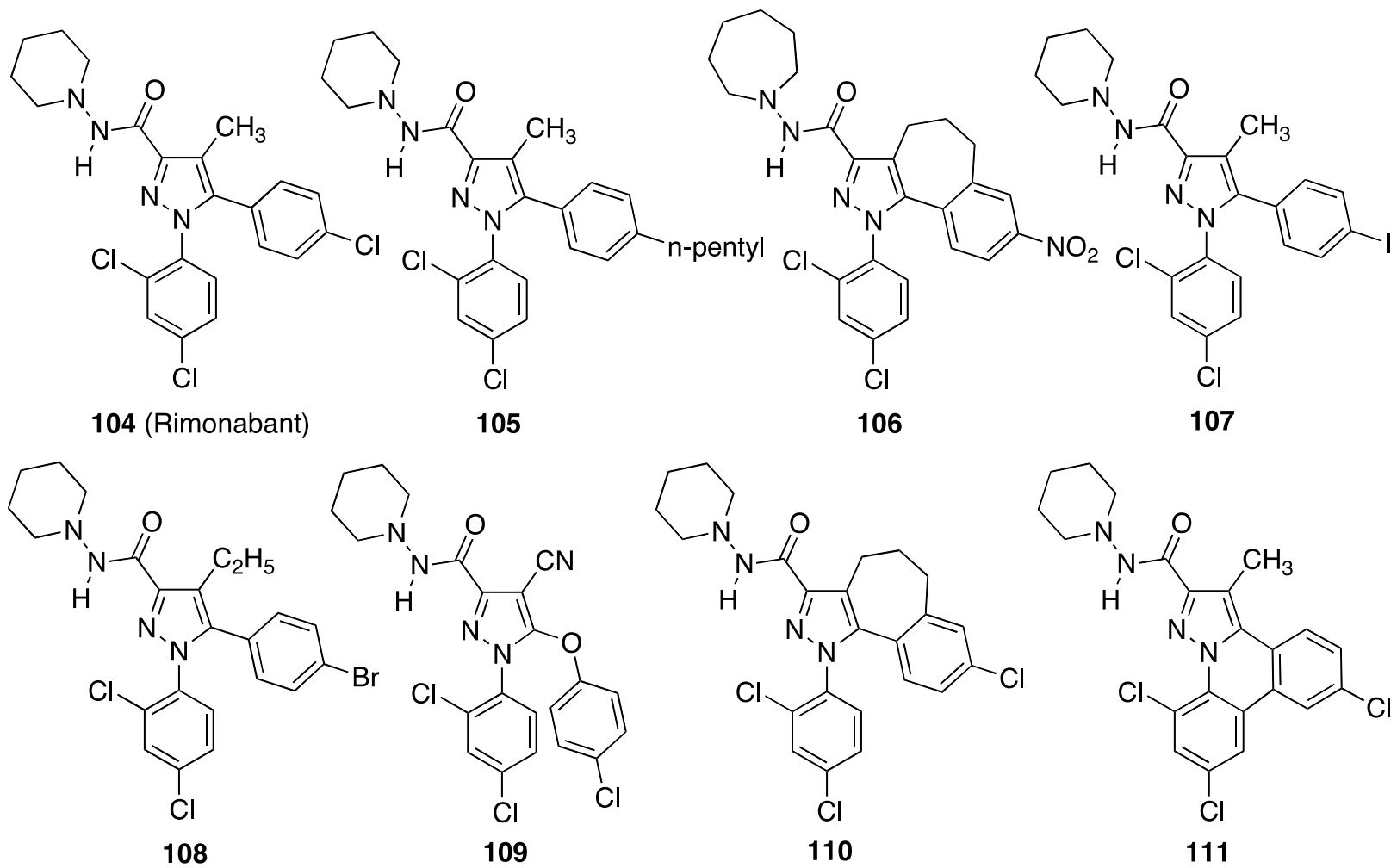

Scheme 10. Rimonabant (104) and related pyrazoles.

A large number of analogues have been described in which all the substituents have been modified: the methyl at $\mathrm{C}-4$, the aromatic rings and their substituents, and the piperidine which has been substituted by other rings and by alkyl chains. ${ }^{105-107}$

Worth mentioning are $\mathbf{1 0 5}$ (OL-1302) with a pentyl chain at the phenyl ring, ${ }^{108} \mathbf{1 0 7}$ (AM251) obtained by replacing the 5-phenyl chloro substituent by iodine which is used as a reference compound in cannabinoid studies, ${ }^{109}$ and $\mathbf{1 0 8}$ (SR147778) which reduced food intake in rats. ${ }^{110}$ Besides, different groups have reported conformationally restricted analogs of Rimonabant such as 106, ${ }^{111} \mathbf{1 1 0}$ with nanomolar affinity for the hCB1 receptor, ${ }^{112}$ referred also as NESS0327 in another publication ${ }^{113}$ and 111. ${ }^{31}$ A patent has been filed for the 5-aryloxypyrazole 109, a CB1 antagonist. $^{31}$ 


\subsection{Ureas}

We have found only one urea derivative, 112 (Doramapimod) investigated as a possible treatment for rheumatoid arthritis. ${ }^{114,115}$

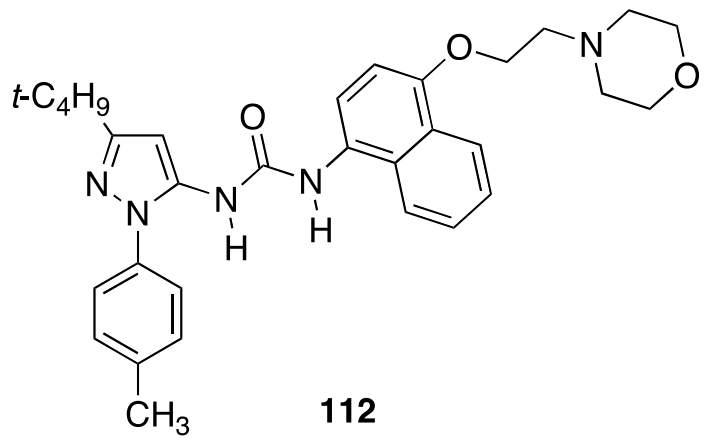

\section{Esters}

There are very few examples of pyrazole esters (Scheme 11).

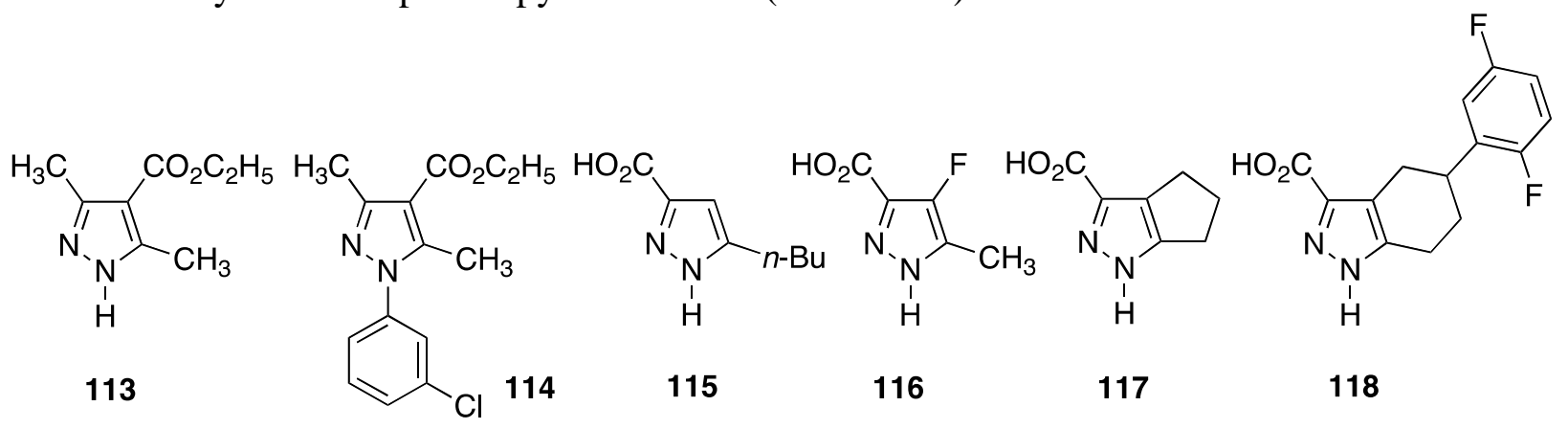

Scheme 11. Pyrazole esters and carboxylic acids.

A library of about 20,000 "scaffold" compounds with molecular weights of 125-350 Da was screened in a combination of biochemical assays and crystallography studies to identify the PDE4 inhibitor pyrazole ester derivative 113. ${ }^{116}$ A 4000-fold increase in potency was achieved after only two rounds of chemical synthesis to give 114. These compounds were designed for the treatment of asthma.

\section{Carboxylic acids}

Three pyrazole-3-carboxylic acids are depicted in Scheme 11. A series of pyrazole-3-carboxylic acids has been reported as partial agonists for the nicotinic acid receptor ${ }^{117}$ aimed to treat atherosclerosis. It was postulated that partial agonism might result in tissue selectivity. The most potent member of the class, 5-butyl-pyrazole-3-carboxylic acid, 115, had the greatest affinity for 
the nicotinic acid receptor as measured by a competitive binding assay using rat spleen membranes. Recent patents claim similar 4,5-dialkyl-pyrazole-3-carboxylic acids, ${ }^{118}$ as nicotinic acid receptor agonists.

Pyrazole carboxylic acid $\mathbf{1 1 6}$ is a selective activator of the niacin receptor GPR109a, an interesting target for the treatment of atherosclerosis and dyslipidemia. ${ }^{119}$

Other pyrazoles with anti-lipidemic activity are compounds 117 and $118 .^{117}$ It has been postulated that compared to full agonists, partial agonists may exhibit reduced adverse effects. Interestingly, compound 117, a partial agonist in the GTPgS (guanosine 5'-O- $[\gamma-$ thio]triphosphate) assay, turned out to be a full agonist in the cAMP whole-cell assay. ${ }^{120}$ In addition, a series of 4-fluoro-5-alkyl pyrazole 3-carboxylic acids were also identified as selective agonists for GPR109a, a G-protein coupled receptor discovered in 1999 using data afforded by the Human Genome Project. As an extension of the cycloalkyl-fused pyrazole carboxylic acids, aryl substituents on the cycloalkyl group, particularly the cyclohexyl group, were also examined. ${ }^{121}$ Compound 118 showed no significant flushing when administered to rats at the dose of $30 \mathrm{mg} / \mathrm{kg}$.

\section{Carbonyl compounds (Pz-CO-R)}

\section{1. $N$-substituted compounds}

Pyrazole 119, identified through HTS, is notable for its lack of a polar head group, and it served as the basis for the proposal of a pharmacophore model for S1P1 (sphingosine-1-phosphate receptor 1) agonism. ${ }^{122}$ The $\mathrm{S} 1 \mathrm{P}$ receptors are related to inflammation.

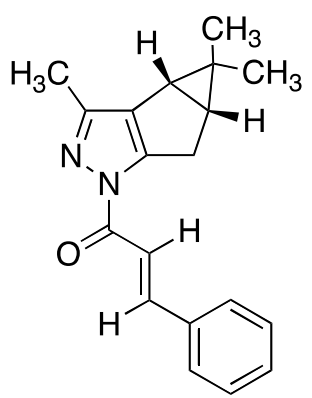

119<smiles>Nc1c(C(=O)c2ccc(Cl)cc2)cnn1-c1ccc(Cl)cc1</smiles>

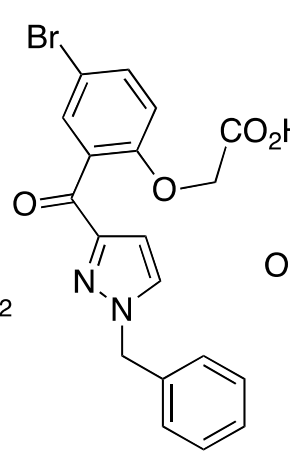

121

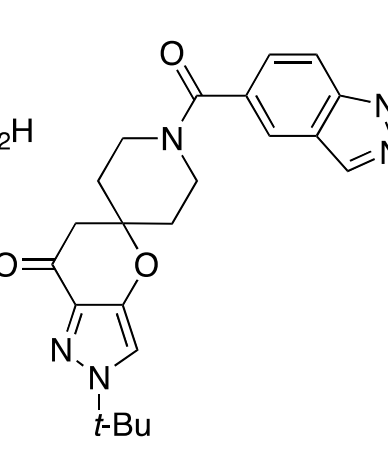

122

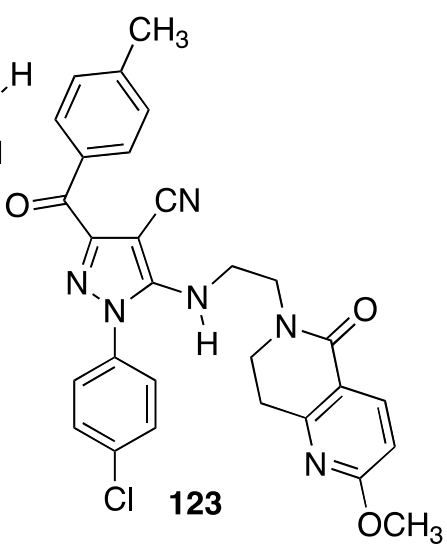

Scheme 12. Pyrazole carbonyl derivatives.

\section{2. $C$-substituted compounds}

The X-ray structure of compound 120, a p38 $\alpha$ inhibitor for treating metabolic diseases, shows a 
hydrogen bonding interaction between the carbonyl oxygen of the benzophenone and Met-109 in p38 $\alpha$. In this case the carbonyl oxygen makes the crucial hydrogen bonding interaction with Met-109. The amino group at the 5 position of the pyrazole ring in compound $\mathbf{1 2 0}$ is involved in forming a hydrogen bond with Thr-106. ${ }^{114,115}$ Compound $\mathbf{1 2 1}$ is a PGD $_{2}$ (Prostaglandin $\mathrm{D}_{2}$ ) antagonist, developed for the treatment of allergic reactions, asthma, rhinitis, etc... ${ }^{123}$ Pyranone 122 has interesting properties as an ACC1 and ACC2 (Acetyl-CoA-carboxylase) inhibitor and was studied for treating metabolic syndrome and diabetes. ${ }^{124}$ Compound $\mathbf{1 2 3}$ which produces weight loss is a Ghrelin receptor inverse agonist. ${ }^{125}$

\section{Amines}

The molecules belonging to Section 8.1 are represented in Scheme 13.

\subsection{Directly linked}

Pyrimidine 124 claimed as a voltage-gated ion channel blocker useful for chronic and neuropathic pain has been described. Apart from screening assays, no other biological or selectivity data were presented, and therefore it is difficult to determine their potential as blockers. ${ }^{126}$ In the obesity field, 5-aminopyrazole 125 is modestly potent $\left(\mathrm{IC}_{50}=15 \mathrm{nM}\right)$ but quite selective over the NPY ${ }_{1}$ and $\mathrm{NPY}_{2}$ receptors. Related pyrazoles with $N$-methyl substituents, either on the $\mathrm{NH}_{2}$ or in the sulfonamide, provide derivatives with reduced affinity for the $\mathrm{Y}_{5}$ receptor. ${ }^{127}$ For the treatment of cardiac arrhythmia, the $\mathrm{K}_{\mathrm{V}} 1.5$ channel antagonist 126 (the active enantiomer) showed long half-life and adequate bioavailability. ${ }^{128}$

One of the most prominent biological properties of aminopyrazoles is as anticancer drugs. 4arylazo-3,5-diamino-1H-pyrazoles are CDK Inhibitors. A large family of these compounds was subject to SAR studies, selectivity, and cellular effects: the most interesting one was $\mathbf{1 2 7}$ whose crystal structure in complex with CDK2 was determined. ${ }^{129}$ A number of inhibitors utilize the pyrimidine scaffold with various substitutions at the 2 and 4 positions. Pyrimidine 128 (XL-228) a representative of one of the series showed IGF-1R activity and advanced into the clinic. 128 is a potent Aurora kinase inhibitor that entered phase I study in patients with solid tumors or hematologic malignancies. A patent has been filed specifically claiming compound 129, which has an $\mathrm{IC}_{50}$ of $4.3 \mathrm{nM}$ with an eight-fold selectivity over the IR (insulin receptor). The aminopyrazole element is common to both $\mathbf{1 2 8}$ and $\mathbf{1 2 9}$ and most likely forms a hydrogen bond with the hinge region of the kinase. ${ }^{130}$ Pyrrolotriazine BMS-754807, 130, was reported as a $2 \mathrm{nM}$ $\left(\mathrm{IC}_{50}\right)$ inhibitor of IGF-1R with no selectivity over IR and is orally active in a transgenically derived, Sal tumor model at a dose of $3 \mathrm{mg} / \mathrm{kg} .{ }^{131}$ The compound is also orally active at $3 \mathrm{mg} / \mathrm{kg}$ in the IGF-1R-driven sarcoma model and the Geo colon carcinoma model at $12 \mathrm{mg} / \mathrm{kg}$. The combination of $\mathbf{1 3 0}$ plus Cetuximab (a monoclonal antibody) is therapeutically synergistic. Initial single ascending dose studies in normal healthy volunteers demonstrated good 
bioavailability and tolerability. Further clinical evaluation was ongoing. ${ }^{132}$ A similarly substituted triazine, 131, is described in the patent literature which inhibits $96 \%$ of tumor growth in the I GF-Sal tumor model at a $3 \mathrm{mg} / \mathrm{kg}$ oral dose. ${ }^{132}$

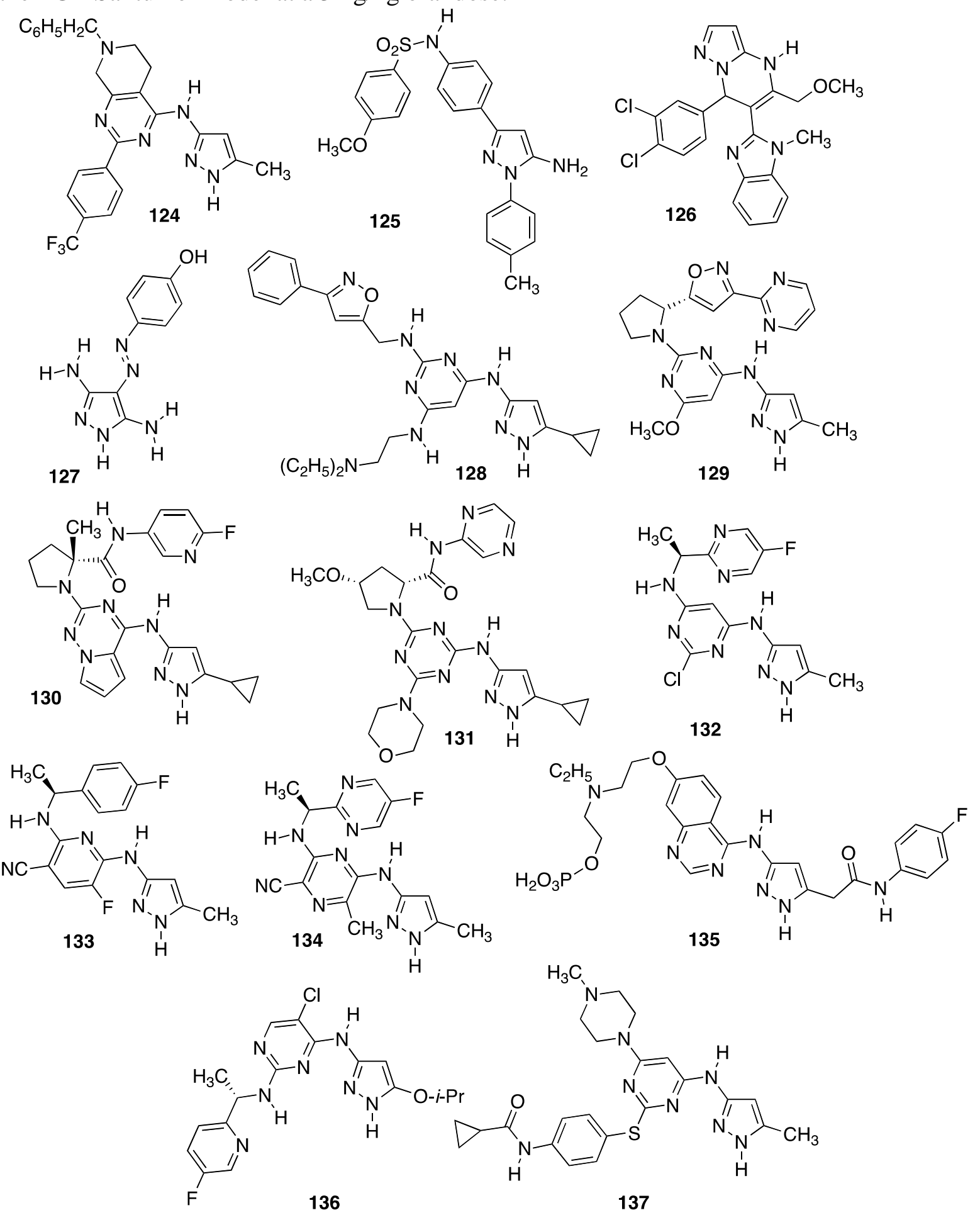

Scheme 13. Pyrazolylamines. 
AZD1480 (132) is a pyrazolyl pyrimidine that reached Phase I clinical trials. The compound is a JAK1 and JAK2 ATP competitive inhibitor. AZD1480 is the first JAK2 inhibitor that suppressed growth of multiple solid tumors with constitutive STAT3 activation, thereby suggesting applicability beyond MPN indications for a JAK2 inhibitor. ${ }^{133}$ AZ960 (133), a pyrazolo-nicotinonitrile analog, was reported to be a tight-binding, ATP-competitive JAK2 inhibitor. AZ960 also induced apoptosis in SET2 cells, which bear a constitutively active JAK2 pathway. ${ }^{134}$ Modification of the $\mathbf{1 3 3}$ structure resulted in the identification of pyrazolylaminopyrazines, exemplified by compound 134. In a mouse pharmacodynamic study, a single oral dose of $\mathbf{1 3 4}(25 \mathrm{mg} / \mathrm{kg})$ demonstrated greater than $95 \%$ inhibition of STAT5 phosphorylation in splenic infiltrates of TEL (gene fusion)-JAK2 transfected Ba/F3 cells. ${ }^{135}$ Compound 135 (AZD-1152) associates with 3 or 4 molecules of water, the stoichiometry depending upon relative humidity and temperature. However, a co-crystal with maleic acid, formed by combining the components in methanol, DMSO/methanol or DMSO at $60{ }^{\circ} \mathrm{C}$ and precipitating by adding $\mathrm{CH}_{3} \mathrm{CN}$, is claimed to be both anhydrous and non-hygroscopic. ${ }^{136}$

Compound 136 (AZ-23), has been described with anticancer properties. ${ }^{137}$ AZ-23 was a potent and selective Trk kinase inhibitor. In vitro studies with AZ-23 showed improved selectivity over previous compounds and inhibition of Trk kinase activity in cells at low nanomolar concentrations. AZ-23 represented a potent and selective Trk kinase inhibitor from a novel series with the potential for use as a treatment for cancer. ${ }^{138}$

The Aurore kinase inhibitor, VX-680 (137), inhibited TbAUK1 (T. brucei Aurore kinase) and disrupted cell cycle progression in the parasite $T$. brucei that causes African trypanosomiasis. ${ }^{139}$

\subsection{With a spacer}
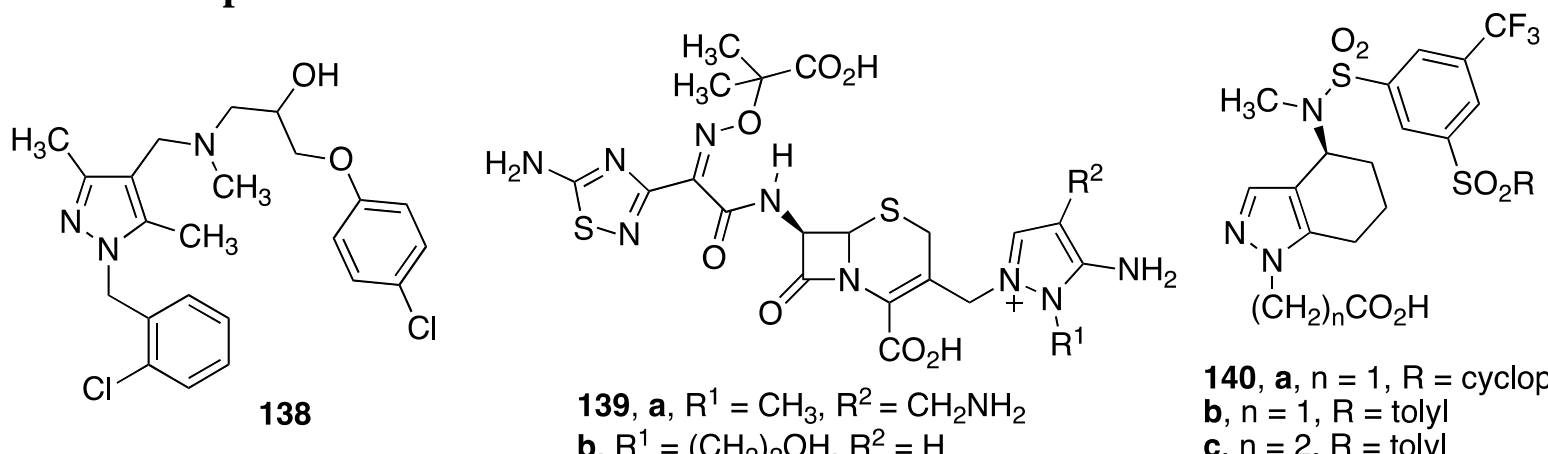

$140, a, n=1, R=$ cyclopentyl

b, $\mathrm{R}^{1}=\left(\mathrm{CH}_{2}\right)_{2} \mathrm{OH}, \mathrm{R}^{2}=\mathrm{H}$

b, $\mathrm{n}=1, \mathrm{R}=$ tolyl

c, $n=2, R=$ tolyl

Scheme 14. Aminomethylenepyrazoles.

$N$-Benzylpyrazole 138 (Scheme 14) inhibits LPS-induced nitric oxide production by binding to the MD2 (a 17 residue peptide) region that interacts with lipopolysaccharide-stimulated human whole blood. This kind of compounds may offer a new starting point for medicinal chemistry efforts to provide orally available TLR4 (Toll-like receptor 4) antagonists useful to treat CNS diseases. ${ }^{140}$ 
The excellent MIC results for FR26420 (139a), particularly against $\beta$-lactamase-producing strains was attributed to an extended SAR effort aimed at increasing the steric effect on the 3position of the cephem nucleus culminating with the 4-position side chain on the pyrazolium ring. Key analogs (139a and 139b) in the SAR regression illustrate the trend, with ceftazidime as a reference, in an experiment with an AmpC $\beta$-lactamase over-producing strain (FP 1380). ${ }^{141}$ A series of pyrazole acetic acids have been disclosed including 140a and 140b which possess CRTh2 (chemoattractant receptor homologous molecule expressed on Th2 cells; also known as DP2 or GPR44 or CD294) binding IC 50 of $3 \mathrm{nM} .^{142}$ Interestingly, several propionic acid analogs, exemplified by 140c, maintained high CRTh2 affinity (binding $\mathrm{IC}_{50}=3 \mathrm{nM}$ ).

\section{Alcohols and ethers}

\subsection{Directly linked}

The main fields of application of compounds of this section are diabetes, inflammation and pulmonary diseases (Scheme 15).

Niacin (nicotinic acid) at high doses ( $>1 \mathrm{~g} /$ day) favorably modulates the human lipid profile by elevating high-density lipoprotein cholesterol (HDL-C) and decreasing low-density lipoprotein cholesterol (LDL-C), very low-density lipoprotein cholesterol (VLDL-C), triglycerides (TG), and lipoprotein a [Lp(a)]. Amongst other compounds, two 3hydroxypyrazoles, 141 and 142, showed affinity for the high-affinity niacin receptor GPR109a behaving as antagonists. ${ }^{143}$

In the field of Type 2 diabetes mellitus (T2DM), a patent disclosure detailed extensive efforts directed toward surrogates for the phenylacetic acid moiety of GW3965 (a non-steroidal liver X receptor agonist) as exemplified by pyrazole 143. ${ }^{144}$ Following a cyclase-based HTS campaign, pyrimidine 144 was identified as an inverse agonist of GPR119. ${ }^{145}$ Optimization of $\mathbf{1 4 4}$ led to other GPR119 agonists. ${ }^{146}$ In the field of T2DM, compound 145, a glucoside-based SGLT2 (sodium glucose co-transporter 2) inhibitor, entered development but was discontinued due to lack of sufficient stability in the gut and post-absorption. ${ }^{147}$

In the field of inflammation, diaryl substituted pyrazoles have also been described as potent CCR2 antagonists. The diaryl pyrazole core was quite resistant to change. Compound 146 proved to be the most CCR2 active and also exhibited good selectivity over CCR5. ${ }^{148}$ 

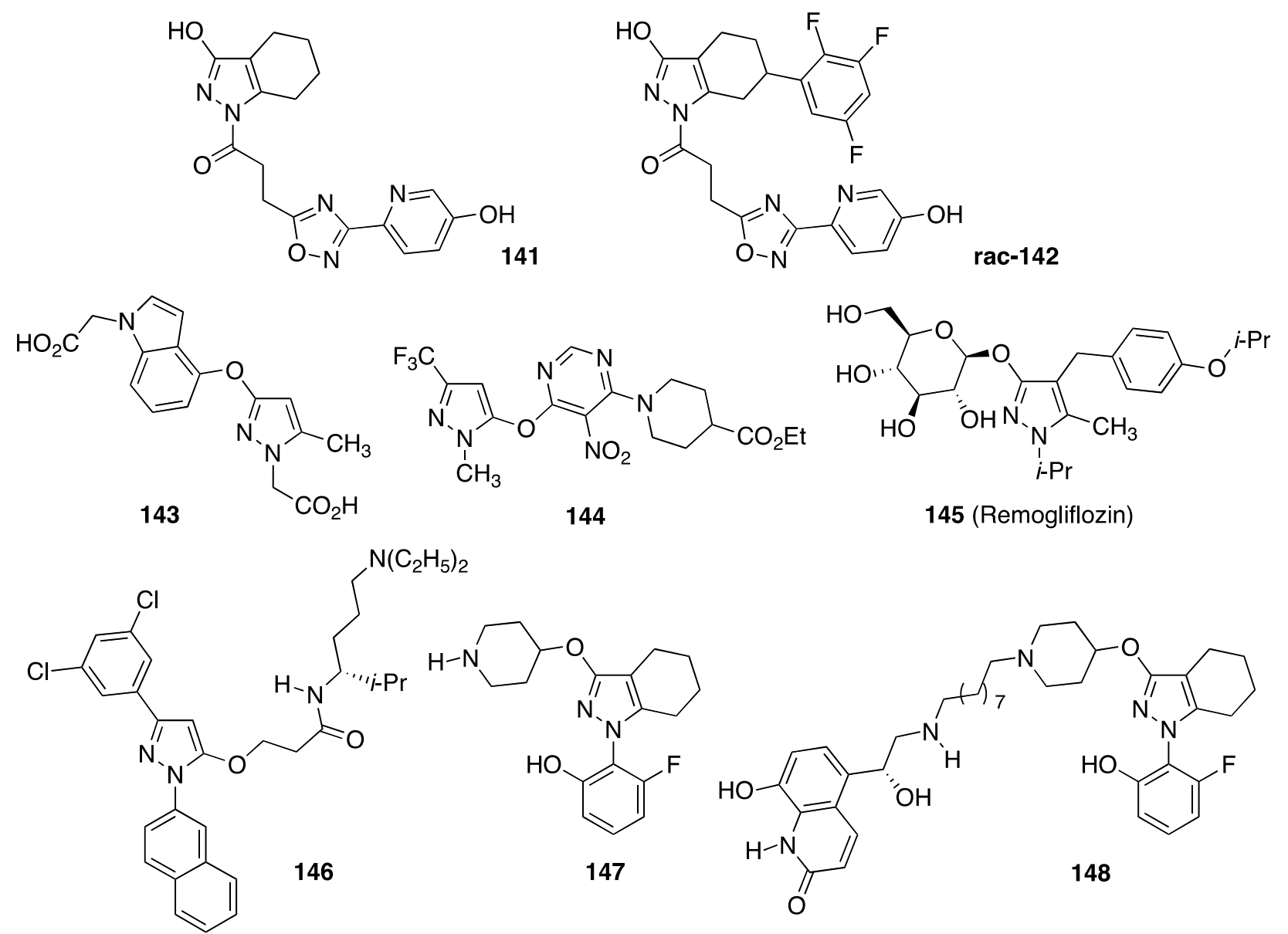

Scheme 15. Hydroxypyrazoles and their derivatives.

Related to pulmonary diseases such as COPD (Chronic obstructive pulmonary disease) are pyrazoles 147 and 148 that have unique muscarinic pharmacophores. One such example 146 began with a novel, selective M3 antagonist 147 which evolved from a nonselective norepinephrine reuptake inhibitor. ${ }^{149}$ Compound $\mathbf{1 4 8}$ has high clearance in microsomes and poor membrane permeability, a favorable profile for an inhaled therapeutic.

\subsection{With a spacer}

In search for new compounds to treat inflammation, different classes of dual inhibitors have been described that combine the two key pharmacophores associated with known 5-LO (5lipoxygenase) and COX inhibitors. Compounds 149 and 150 exemplify one of these classes, dual inhibitors that combine the pyrazole triaryl motif of the selective COX-2 inhibitor Celecoxib (218) with the tetrahydropyranylphenyl pharmacophore found in the non-redox 5-LO inhibitor ZD-2138. They displayed balanced 5-LO/COX-2 inhibition and are as efficacious as Zileuton and Rofecoxib in a rat model of AA-induced ear edema. ${ }^{150,151}$ 

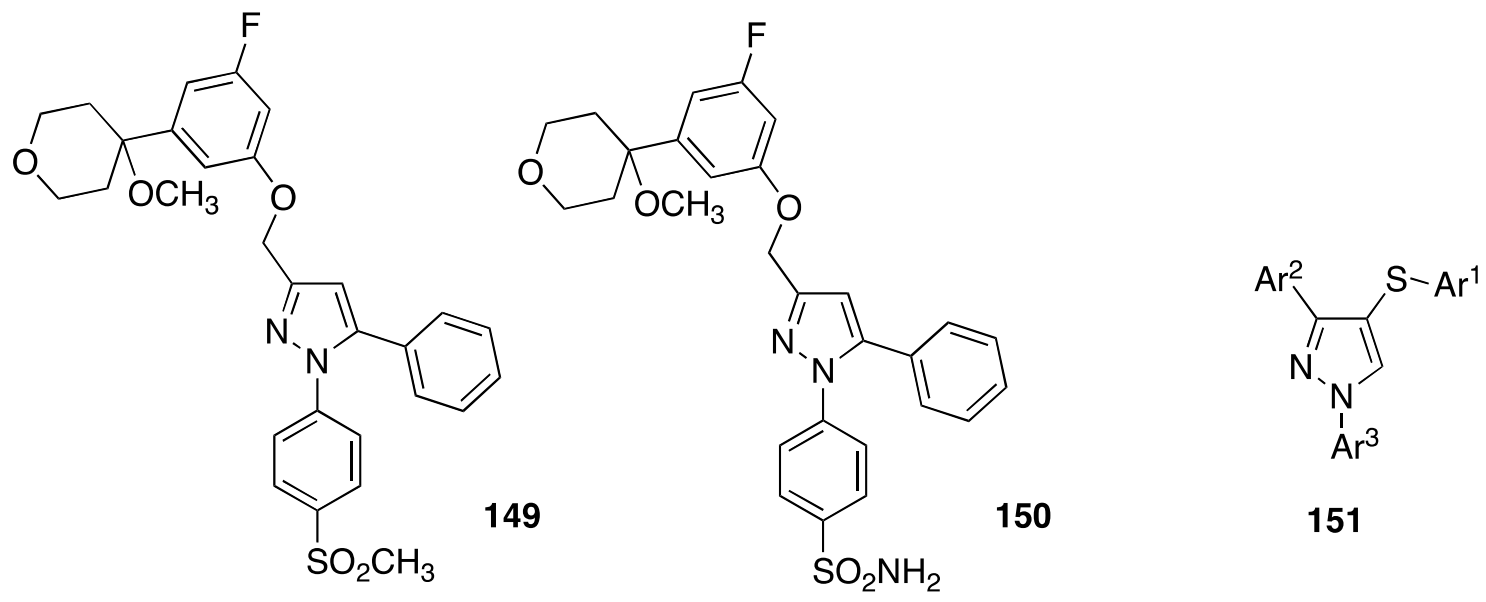

151

Scheme 16. Derivatives of hydroxymethylenepyrazoles

\subsection{With a N-O bond}

$N$-Hydroxypyrazoles and pyrazole $N$-oxides are not very common compounds, but compound 84 is included in Section 4.2.

\section{Thiols and thioethers}

A series of compounds of general formula $\mathbf{1 5 1}$ (Scheme 16) are non-covalent FAAH (fatty acid amide hydrolase) inhibitors and therefore potentially useful for pain treatment. In no case has the in vivo analgesic efficacy been reported for these compounds. However, assuming these compounds are indeed active in vivo, they would provide an alternative approach to irreversible covalent inhibitors that might eliminate potential safety concerns over the creation of long-lived covalent adducts between compounds and the FAAH enzyme. ${ }^{152}$

\section{Aromatic substituents}

\section{1. $N$-substituted compounds}

11.1.1. Directly linked. One of the $N$-aryl derivatives summarized in Scheme 17 is the pyrazolecontaining hydroxamic acid 152, also known as Tepoxalin, a non-steroidal anti-inflammatory drug with a dual action 5-LO/COX. ${ }^{153}$ It is prescribed for treatment of pain and inflammation associated with canine osteoarthritis. Structurally related to the redox 5-LO inhibitor ABT-761 bearing an acetylenic $N$-hydroxy urea group is compound 153. In a canine blood ex vivo assay this dual inhibitor displayed a short-lived inhibition of COX and 5-LO. ${ }^{154}$ 
Compounds 154 (ER-34122) and $\mathbf{1 5 5}$ are examples of pyrazoles with three aryls based on Celecoxib and Tepoxalin structures exhibiting a dual inhibition profile. ${ }^{155,156}$ Moreover, 154 resulted to be 3- to 10-fold less potent than Indomethacin in inhibiting carrageenan-induced rat paw edema. Diaryl substituted pyrazoles have also been described as potent CCR2 antagonists. Compound 156 showed CCR2 $\left(\mathrm{IC}_{50}=221 \mathrm{nM}\right)$ and CCR5 $\left(\mathrm{IC}_{50}=63 \mathrm{nM}\right)$ activity. ${ }^{148}$

The V2 receptor is mainly localized in the kidney and is responsible for fluid homeostasis. Compound 157 reached phase II clinical trials for enuresia. ${ }^{157}$ A potent generation of GPR109a agonists was discovered after hybridization of bicyclic and biaryl anthranilides. One of these compounds, 158, showed good activity against GPR109a, a good mouse PK profile, a superior TI over niacin regarding FFA reduction and vasodilation effects in rats, and minimal CYP2C8 (Cytochrome $\mathrm{P}_{450} 2 \mathrm{C} 8$ ) and CYP2C9 (Cytochrome $\mathrm{P}_{450}$ 2C9) inhibition liability. ${ }^{158}$

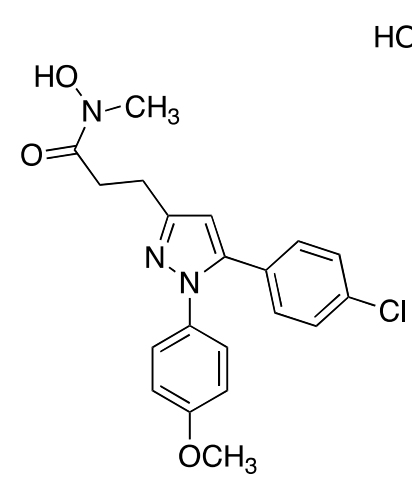

152 (Tepoxalin)

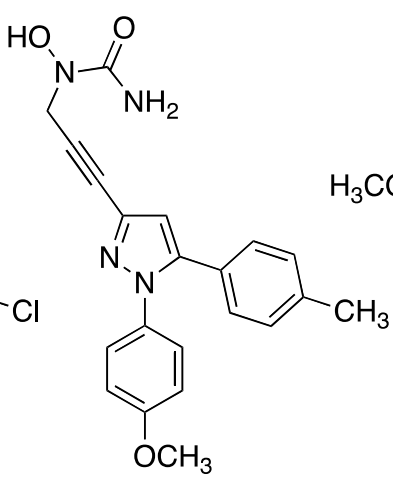

153

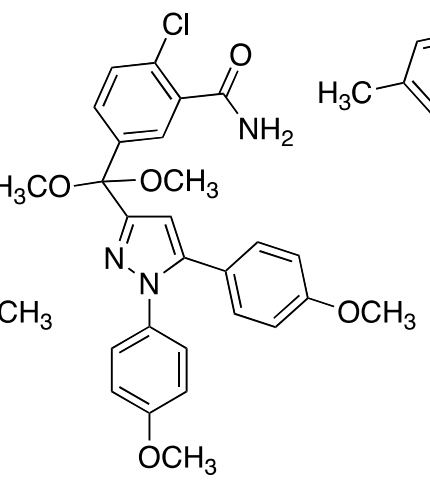

154

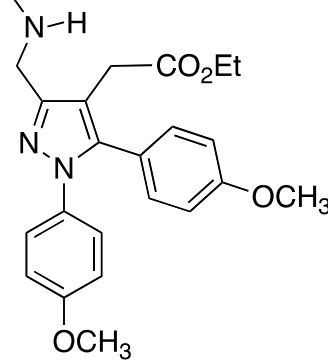

155<smiles>COC(=O)[C@H](CCCNC(=N)N)NC(=O)CCCc1cc(-c2cc(Cl)cc(Cl)c2)nn1-c1ccc2ccccc2c1</smiles><smiles>Cc1ccn(-c2ccc(C(=O)N3Cn4cccc4Cc4ccccc43)c(Cl)c2)n1</smiles>

157<smiles>CC(C)(C)C(C)(C)C</smiles><smiles>NC(Cc1cnn2c1CCc1cc(O)ccc1-2)C(=O)Nc1ccccc1C(=O)O</smiles><smiles>C/C=C\CCCCn1c(-c2cc(Cl)ccc2-n2ccc(C)n2)nc2cc(-c3cnc(N)nc3)ccc21</smiles><smiles>CO</smiles><smiles>CCc1c(-c2ccc(O)cc2)nn(-c2ccc(O)cc2)c1-c1ccc(O)cc1</smiles><smiles>CCc1c(-c2ccc(O)cc2)nn(-c2ccc(O)cc2)c1-c1ccc(OCCN2CCCCC2)cc1</smiles> 

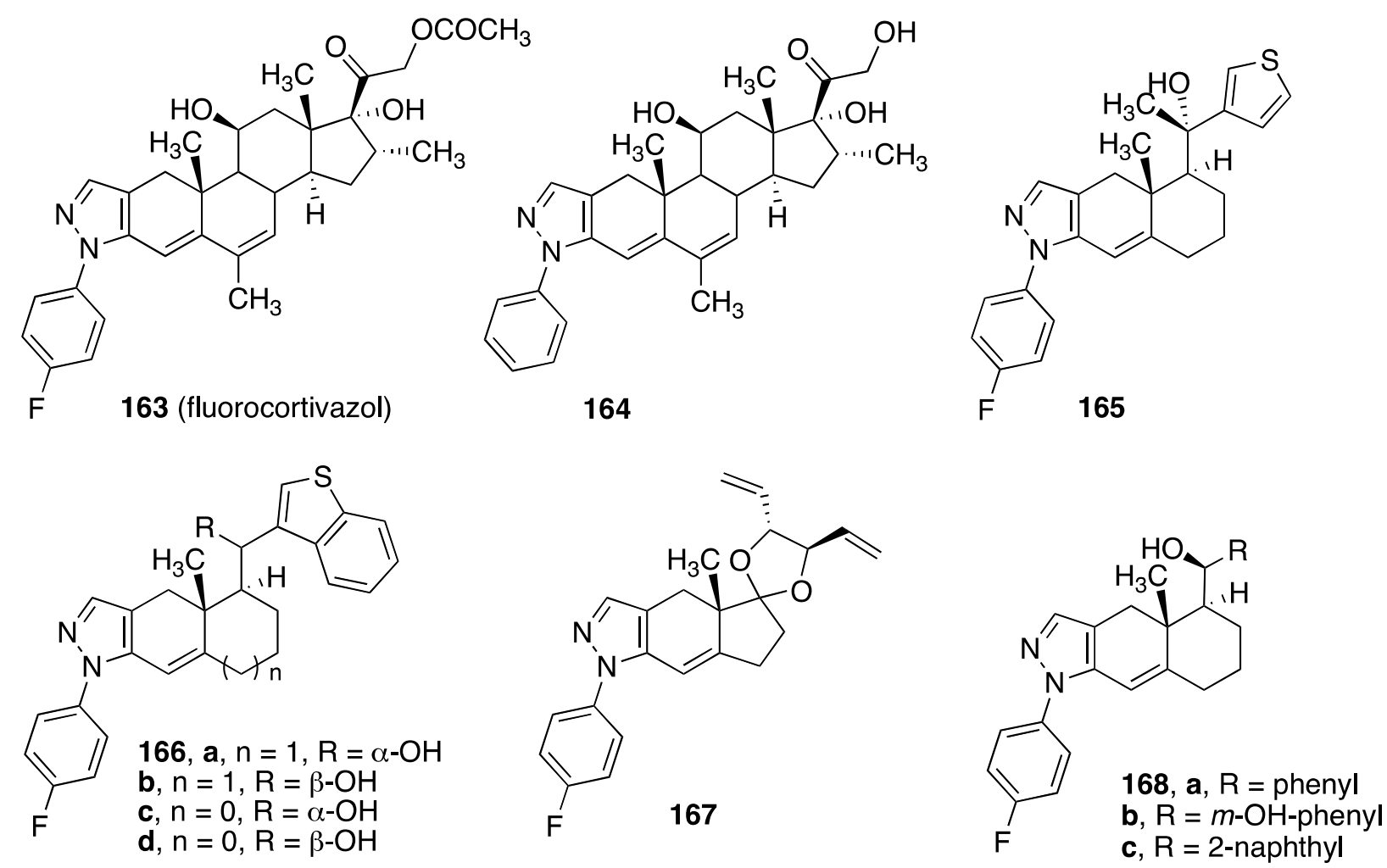

Scheme 17. $N$-arylpyrazoles.

A strategy to obtain new compounds was achieved replacing the phenyl group of anthranilic acid by a cycloalkene. Additionally, substitution of the central ethylene linker by an amino group was reported being 159 an example. This may have beneficial effects such as better physical properties and a reduced $\mathrm{IC}_{50}{ }^{159} \mathrm{LT}$ signaling is known to be involved in processes associated with atherosclerosis. Several patent applications related to FLAP inhibitors of different scaffolds such as benzimidazoles (e.g. 160) have been reported. ${ }^{160}$

The unique tissue selectivity found in selective estrogen receptor modulators (SERMs) has proven beneficial for the treatment of diseases such as breast cancer and osteoporosis. They mimic estrogen (E2) in some tissues, such as bone, while suppressing its effects in other tissues, such as the breast and uterus. The transformation of ERa agonists into modulators has been achieved by appending a basic side chain at the appropriate position. An example can be found in the transformation of the pyrazole agonist 161. Attaching a piperidinylethyl side chain it is transformed into compound 162, a full antagonist on ERa (IC $5_{50} \sim 20 \mathrm{nM}$ ) and is $\sim 18$-fold selective for ERa. ${ }^{161}$

Compounds 163 and 164 were reported as glucocorticoid receptor (GR) agonist analogs of Fluorocortivazol. ${ }^{162}$ Modifications of the C- and D-rings of $\mathbf{1 6 4}$ led to compound $\mathbf{1 6 5}\left(\mathrm{IC}_{50}=0.8\right.$ $\mathrm{nM}$ ) without losing activity. This potent GR ligand showed activity in both TR (interleukin 6 (IL-6) inhibition in human A549 lung carcinoma cells $\left(\mathrm{EC}_{50}=1.0 \mathrm{nM}, 97 \%\right.$ efficacy) and TA (tyrosine amino transferase (TAT) induction in human HepG2 cells $\left(\mathrm{EC}_{50}=36 \mathrm{nM}, 69 \%\right.$ 
efficacy) functional assays. In a lipopolysaccharide-stimulated mouse model of tumor necrosis factor-alpha production (LPS-TNFa) 165 showed an $\mathrm{ED}_{50}$ of $4 \mathrm{mg} / \mathrm{kg}$ (p.o.). ${ }^{163}$

Conversion of the thiophene ring to benzothiophene and removal of the tertiary methyl group (166a) did not affect GR binding affinity $\left(\mathrm{IC}_{50}=1.5 \mathrm{nM}\right)$ or dissociative activity in TR and TA assays. ${ }^{164}$ Changing to the other hydroxyl epimer (166b) does not influence GR binding, although it confers dissociation when examined in TR (IL-6 inhibition $\mathrm{EC}_{50}=18 \mathrm{nM}, 86 \%$ efficacy) and TA (TAT efficacy 21\%) assays. Contracting the B-ring of 166a and 166 brom a 6to a 5-membered ring (166c and 166d) affected the biological and pharmacokinetic (PK) properties. $^{165}$

Compound 166c showed its effectiveness in the TR assay (IL-6 inhibition $\mathrm{EC}_{50}=10 \mathrm{nM}$, $92 \%$ efficacy) but resulted less efficacious in the TA assay (TAT induction $\mathrm{EC}_{50}=675 \mathrm{nM}, 62 \%$ efficacy). Besides, 166c improved the PK profile and notably reduced in vivo TNFa production. In contrast, 166d, the hydroxyl epimer of 166c, was less effective in TR and TA assays (IL-6 inhibition $\mathrm{EC}_{50}=5 \mathrm{nM}, 71 \%$ efficacy; TAT efficacy $29 \%$ ).

Replacing the conventional C- and D-rings of steroidal glucocorticoids with a variety of substituted ketals differing in ring size resulted in a novel series of potent and selective nonsteroidal ligands with a comparable GR binding potency and steroid receptor selectivity in vitro to that of marketed glucocorticosteroids. ${ }^{166}$ For instance, $\mathbf{1 6 7}$ is a potent and selective GR ligand (GR $\mathrm{IC}_{50}=8 \mathrm{nM}$ ) with a partial agonism profile in TR and TA assays (IL-6 inhibition $\mathrm{EC}_{50}=2.6 \mathrm{nM}, 58 \%$ efficacy; TAT efficacy $11 \%$ ). Its good murine PK profile led to an effective $\mathrm{TNFa}$ inhibition in vivo $\left(\mathrm{ED}_{50}=14 \mathrm{mg} / \mathrm{kg}\right.$, p.o.).

Other C- and D-ring modified Fluorocortivazol analogs such as $\mathbf{1 6 8 a}$ and $\mathbf{1 6 8 b}$ were tested for TA and TR in osteosarcoma cells. ${ }^{167}$ They showed equal affinity for GR $\left(\mathrm{IC}_{50}=5-8 \mathrm{nM}\right)$ and full agonism activities in TR assays (nuclear factor $\mathrm{kB}(\mathrm{NFkB}) \mathrm{EC}_{50}=3 \mathrm{nM}, 63-68 \%$ efficacy; activating protein 1 (AP-1) $\mathrm{EC}_{50}=3 \mathrm{nM}, 73-112 \%$ efficacy) and a TA assay (mouse mammary tumor virus, MMTV) $\mathrm{EC}_{50}=3 \mathrm{nM}, 99-133 \%$ efficacy). Nevertheless, analog 168c (GR $\mathrm{IC}_{50}=2$ $\mathrm{nM})$ resulted to be more potent in the AP-1 assay $\left(\mathrm{EC}_{50}=3 \mathrm{nM}, 71 \%\right.$ efficacy) than the NFkB $\left(\mathrm{EC}_{50}=74 \mathrm{nM}, 54 \%\right.$ efficacy $)$ and the MMTV assays ( $\mathrm{EC}_{50}=22 \mathrm{nM}, 127 \%$ efficacy). Their ability to affect 17 GR target genes was studied using quantitative real-time PCR in A549 human lung adenocarcinoma cells. ${ }^{168}$ This study showed that subtle differences in the shape of the ligands has a great influence on the transcriptional regulatory activities of GR, and the endogenous genes bearing natural GREs.

11.1.2. With a spacer. Treatments based on glucagon receptor antagonists are expected to improve the glycemic control in T2DM patients. Several pyrazole-based analogs have appeared in the patent literature. ${ }^{169}$ Their main structural characteristics can be summarized as follows: three substituents around the pyrazole nucleus one of which is a $\beta$-alanine or aminotetrazolederived benzoyl group. Attention has been focused on pyrazoles 169 and $\mathbf{1 7 0}$ in which the pyrazole ring is substituted by an aryl and a fused bicyclic aryl ring system. Phenyl pyrazoles bearing an alkoxy- and trifuoromethyl-phenyl substitution like $\mathbf{1 6 9}$ exhibited a potent binding 
and functional activity towards human glucagon receptor (hGCGR cAMP IC $_{50}=5-50 \mathrm{nM}$ ). Besides, chloro-substituted derivatives such as $\mathbf{1 7 0}$ displayed moderate to high binding affinities (hGCGR IC $50=1-500 \mathrm{nM}$ ). Pyrazole derivative 171 substituted with a bicyclic heteroaryl group has also been included in a patent application as well as the diphenyl-substituted pyrazole exemplified by $\mathbf{1 7 2}$ and cycloheteroalkyl-substituted pyrazoles such as $\mathbf{1 7 3}$. Finally, pyrazole carboxamides such as $\mathbf{1 7 4}$ were disclosed with moderate to high binding affinity $\left(\mathrm{IC}_{50}=1-500\right.$ $\mathrm{nM})$.

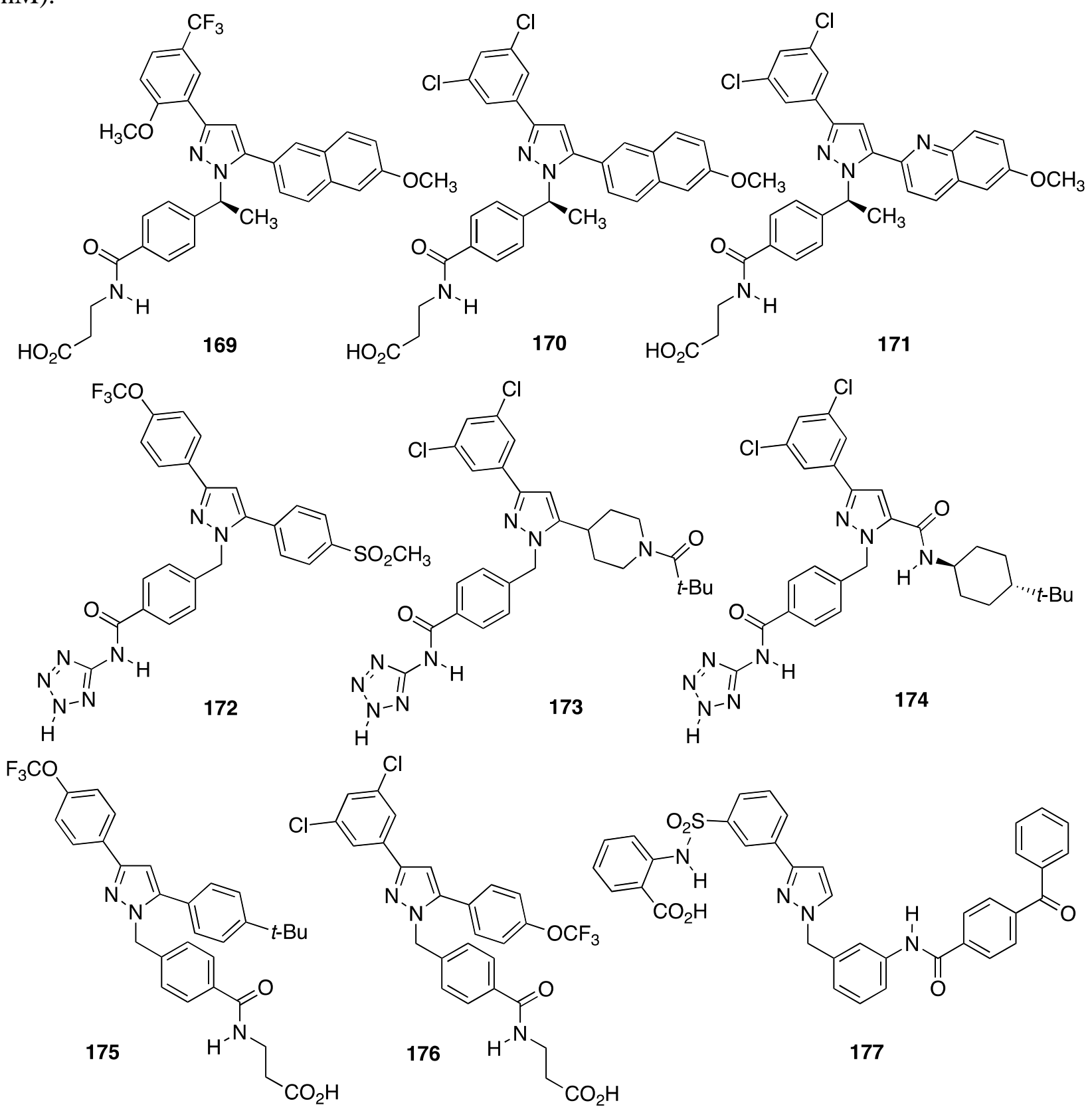

Scheme 18. $N$-benzylpyrazoles. 
A novel series 1,3,5-pyrazoles of glucagon receptor antagonists were published in 2011 with improved PK and PD properties; amongst them, compound 175 had hGCGR IC 50 values of 480 $\mathrm{nM}$ and $\mathbf{1 7 6}$ had an $\mathrm{IC}_{50}=95 \mathrm{nM} .{ }^{170}$

Compound 177 was reported as a Dengue virus inhibitor. Pyrazole derivative 177 irreversibly inhibited NS5pol $\left(\mathrm{IC}_{50}=1.5 \mu \mathrm{M}\right)$. Based on a structural analysis of the available Xray structure and docking experiments, a binding mode was proposed at a site between the "finger" and "thumb" regions of the polymerase. ${ }^{171}$

\section{2. $C$-substituted}

Scheme 19 compiles C-arylpyrazoles with a great variety of applications, from analgesia to metabolic syndrome, cancer and HCV. Non-selective sodium channel blockers are used as analgesics. $\mathrm{Na}_{\mathrm{v}}$ channels are formed by a pore forming alpha subunit and an auxiliary beta subunit. In 2010, a patent application disclosed a series of potent $\mathrm{Na}_{\mathrm{v}} 1.7$ blockers. ${ }^{172}$ Estimated $\mathrm{IC}_{50}$ values for $\mathrm{Na}_{\mathrm{v}} 1.7$ using a PatchXpress platform were reported in the single nanomolar to picomolar range for a number of examples. One of the compounds prepared in multigram quantities was compound $\mathbf{1 7 8}$.

A way to develop small molecules to disrupt protein-protein interactions is a strategy known as fragment assembly. Fragments with affinity for the target are connected to yield more potent molecules. Based on lead compound $\mathbf{1 7 9}$ and following this methodology, a potent small inhibitor $180\left(\mathrm{IC}_{50}=60 \mathrm{nM}\right)$ of the IL-2 I IL-2Ra was found. ${ }^{173}$

Cat $\mathrm{S}$, found predominantly on antigen presenting cells, has been considered a therapeutic target for asthma. Progress towards Cat $\mathrm{S}$ selective inhibitors has been reported such as pyrazolebased inhibitor JNJ-10329670 (181) with a Cat S potency $\left(\mathrm{IC}_{50}=100 \mathrm{nM}\right)$ and selectivity over other cathepsins including Cats $\mathrm{K}$ and $\mathrm{L}\left(\mathrm{IC}_{50}>50 \mu \mathrm{M}\right) .{ }^{174}$ The azaindole 182 showed an improvement as Cat $\mathrm{S}$ inhibitor $\left(\mathrm{IC}_{50}=30 \mathrm{nM}\right)$ and in the cellular tests $\left(\mathrm{IC}_{50}=38 \mathrm{nM}\right){ }^{175}$

For the treatment of type 2 diabetes and metabolic syndrome the pharmacological inhibition

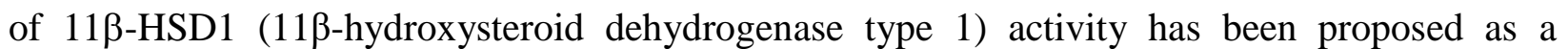
therapeutic strategy. Triazoles belong to a class of $11 \beta$-HSD1 inhibitors and have been covered in the patent literature. Besides, pyrazole derivatives have also shown $11 \beta$-HSD1 potency. For instance, compound $\mathbf{1 8 3}$ had a reported $\mathrm{IC}_{50}$ value of $<10 \mathrm{nM}$. ${ }^{176}$

Dual inhibitors of ACC1 and ACC2 based on a conserved spirochromanone core have been reported. A more recent patent expanded the scope of the structures (e.g. 184, 100\% inhibition of human ACC1 and ACC2 at $1 \mu \mathrm{M}) .{ }^{177}$ It was also found that a number of five-membered heterocyclic rings could be located at the 6 position of the spirochromanone ring such as pyrazole 185 (rat $\mathrm{ACC} 1 \mathrm{IC}_{50}=7.4 \mathrm{nM}, \mathrm{LE}=0.34$ ). The pyrazole derivative 186 was reported as a non- $\mathrm{N}$-hydroxyurea selective non-redox 5-LO inhibitor showing an $\mathrm{IC}_{50}$ of $130 \mathrm{nM}$ in a human whole blood assay.

Cystic fibrosis (CF) is a lethal genetic illness caused by mutations in the gene encoding the CF transmembrane conductance regulator (CFTR), an epithelial chloride-and bicarbonate- 
selective ion channel activated by cyclic AMP-dependent protein kinase A. HTS identified the CFTR enhancer 187 exhibiting a measured $\mathrm{EC}_{50}$ of $2.4 \mu \mathrm{M} .{ }^{178}$<smiles>CN1CC(n2nccc2-c2cc(Cl)ccc2Oc2cc(F)c(S(=O)Nc3ncns3)cc2F)C1</smiles>

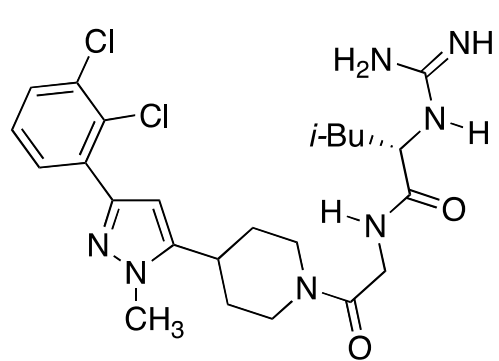

179

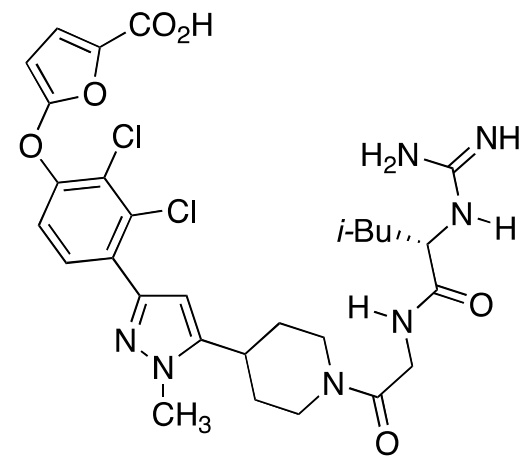

180<smiles>Cn1c(=O)n(C2CCN(CCCn3nc(-c4ccc(C(F)(F)F)cc4)c4c3CCN(S(C)(=O)=O)C4)CC2)c2cc(Cl)ccc21</smiles>

$\mathrm{F}_{3} \mathrm{C}$<smiles>COS(=O)(=O)N1CCc2c(c(-c3ccc(C)cc3)nn2CC(O)CN2CCC(c3c[nH]c4cnccc34)CC2)C1</smiles><smiles>Cc1c(-c2ccc(Cl)cc2Cl)n[nH]c1C1(c2ccccc2)CC1</smiles>

183<smiles>CCOc1cc(C(=O)N2CCC3(CC2)CC(=O)c2cc(-c4nnn[nH]4)ccc2O3)cc(OCC)c1-c1cnn(C)c1</smiles><smiles>Cn1nccc1-c1ccc(Sc2cccc(C3(C(N)=O)CCOCC3)c2)cc1</smiles>

186<smiles>Cc1ccc(O)c(-c2cc(-c3ccccc3)[nH]n2)c1</smiles>

187<smiles>Cc1cc(C(=O)N2CCC3(CC2)CC(=O)c2ccccc2O3)cc2cn[nH]c12</smiles><smiles>NCCC(c1ccc(-c2cn[nH]c2)cc1)c1ccc(Cl)c(F)c1</smiles> 


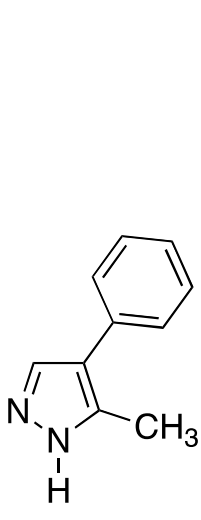

190
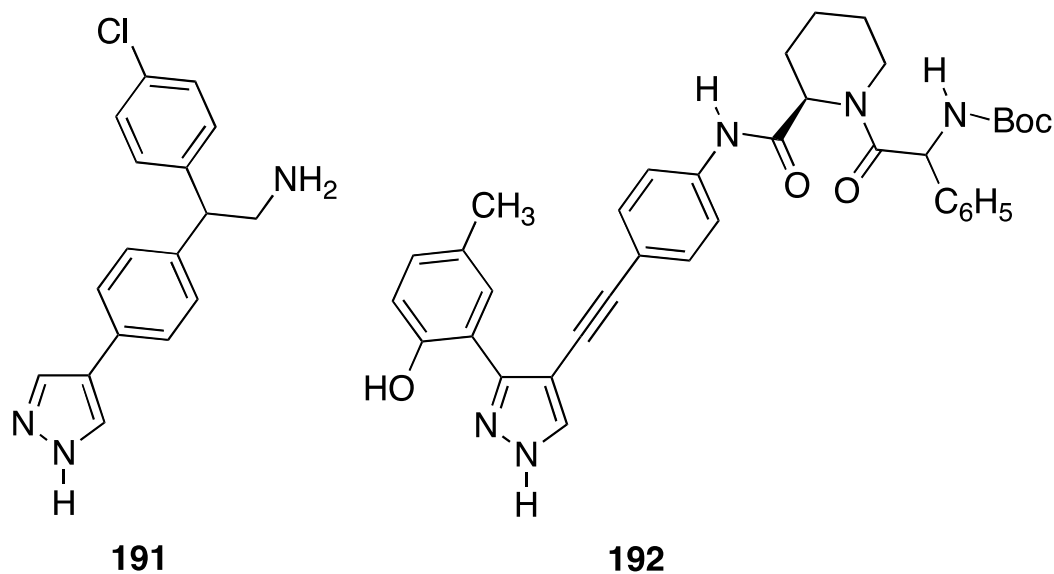

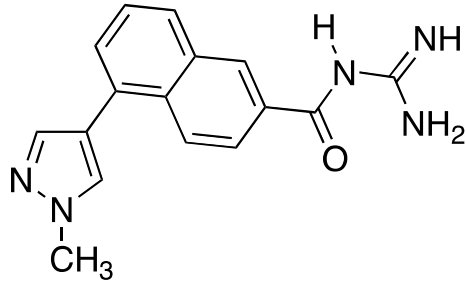

$193(\mathrm{BIT}-225)$

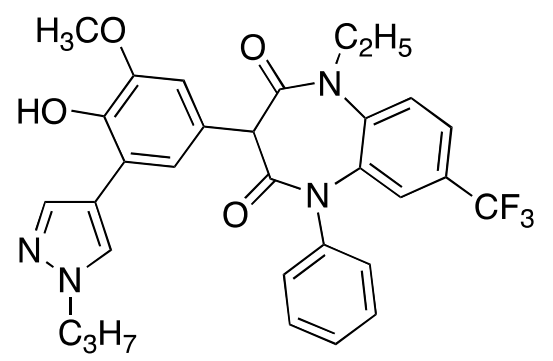

194

Scheme 19. $C$-Arylpyrazoles.

Small molecular scaffolds have been pursued in order to circumvent the disadvantages associated to natural products inhibitors of Hsp90. As an example, pyrazole CCT018159 (188) was reported. ${ }^{179}$ It maintained the critical binding resorcinol moiety of radicicol, inhibited the ATPase activity of Hsp90 with a low micromolar $\mathrm{IC}_{50}$ as well as the proliferation of several tumor cell lines at similar concentrations $(\sim 8 \mu \mathrm{M})$.

PI3K/Akt pathway is considered a potential target for cancer therapy. A series of pyrazoles were disclosed in a patent application as AKT inhibitors, ${ }^{180}$ pyrazole 189 showing an AKT activity of $\mathrm{IC}_{50}<0.1 \mu \mathrm{M}$.

Another target for cancer therapy closely related to the PI3K/Akt pathway is the PKB (Akt). $\mathrm{PKB}$ is involved in the PI3 kinase-PKB-mTOR cellular signaling pathway. Fragment screening (bioassay or X-ray) led to different PKB binding fragments (e. g. 190). From hit 190 and using a fragment growing approach, the lead 191 was obtained and it bound to the ATP pocket. ${ }^{181}$

Compound 192 has been reported as a HCVNS5 inhibitor with an $\mathrm{EC}_{50} \sim 1 \mu \mathrm{M}$. It was included in a patent application of HCVNS5 inhibitors based on homoproline and its isosteres. ${ }^{182}$

Another pyrazole derivative described with antiviral properties is compound 193. It is related to the pestivirus bovine viral diarrhea virus (BVDV), $\mathrm{EC}_{50}=314 \mathrm{nM}$, and HIV-1 in cell culture, $\mathrm{EC}_{50}=2.25 \mu \mathrm{M}$ consistent with inhibition of $\mathrm{Vpu}$ which is involved in virus assembly. ${ }^{183,184}$

Even though the capsid assembly (CA) is common to viral replication and infectivity, it has not been the subject of extensive drug discovery programs until a couple of years ago. Two 
chemical series were identified through NMR spectroscopy as binding to $\mathrm{CA}_{\mathrm{NTD}}$ and inhibiting HIV-1 replication. ${ }^{185}$ A representative of one of the series is compound 194, a benzodiazepine derivative which exhibited an $\mathrm{EC}_{50}=70 \mathrm{nM}$ and low toxicity for a $50 \%$ reduction of cell proliferation against uninfected cells $\left(\mathrm{CC}_{50}\right)$ of $28 \mu \mathrm{M}$.

\section{Aliphatic substituents}

This section is rather artificial. We have placed here compound 195 that has none of the substituents of the previous or subsequent sections. In the field of small molecule inhibitors of IGF-1R, pyrazole 195 (BMS-695735) was discovered showing in vivo efficacy against colon carcinoma and myeloma. ${ }^{186}$ GSK 625433 (196) was reported as a very promising drug for the treatment of hepatitis C by inhibiting the HCV NS5B polymerase. ${ }^{187,188}$
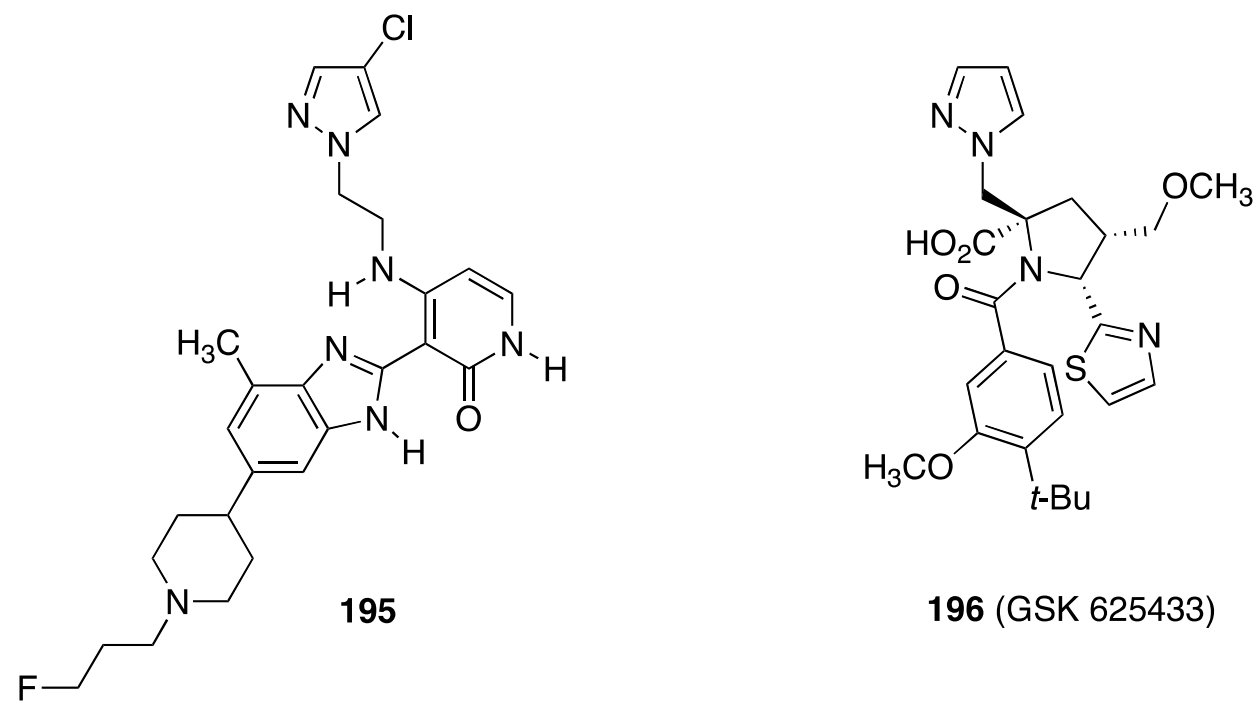

196 (GSK 625433)

Scheme 20. $C$-alkylpyrazoles

\section{Non aromatic compounds}

\subsection{Pyrazolones}

3-Hydroxypyrazoles, although having a pyrazolin-3-one tautomer, exist as 3-hydroxy tautomers and therefore have been discussed in section 9.1.

Edavorone (197) was introduced in the market by Mitsubishi Pharma in 2001 as a neuroprotective agent (improving neurological recovery following acute brain infarction). ${ }^{189}$ Pyrazolin-3,5-dione, 198, an antithrombotic agent, acts as an antagonist of the platelet $\mathrm{P}_{2} \mathrm{Y}_{12}$ 
receptor. ${ }^{190}$ Inhibitors of HIF prolyl hydrolases are useful for the treatment of anemia, amongst them structures 199 (a pyrazolin-5-one) and 200 (a pyrazolin-5-thione). ${ }^{10}$ Capromorelin, CP424,391 (201), a tautomerism blocked pyrazolin-5-one, proved to increase body weight in rats after extended treatment without concomitant changes in body fat or lean mass. ${ }^{191-194}$ It was considered as a Ghrelin mimetic.<smiles>CC1=NN(c2ccccc2)C(=O)C1</smiles>

197 (Edavorone)<smiles>CN1N=C2CCN(C(=O)[C@H](COc3ccccc3)NC(=O)C(C)(C)N)C[C@]2(Cc2ccccc2)C1=O</smiles>

201 (Capromorelin)<smiles>CC1=NN(c2cccc(S(=O)(=O)Nc3ccccc3C(=O)O)c2)C(=O)C1</smiles><smiles>CCOc1ccc(/C=C2\C(=O)N(Nc3ccccc3)N(c3ccccc3)C2=O)c(OC[C@@H](O)CC(=O)O)c1C</smiles>

198<smiles>CC1=NN(c2ccc(C)c(C)c2)C(=O)/C1=N\Nc1cccc(-c2cccc(C(=O)O)c2)c1O</smiles>

202 (Eltrombopag)<smiles>CC(C)(C)OC(=O)c1ccc(-n2[nH]cc(-n3ccnn3)c2=O)cc1</smiles>

199<smiles>COc1ccnc(-n2[nH]cc(-c3cccnc3)c2=S)c1</smiles>

200<smiles>C/C(Nc1ccc(F)cc1)=C1\C=NN(c2ccc(Br)cc2Br)C1=O</smiles>

203<smiles>CC1=NN(c2ccc(C(=O)O)cc2)C(=O)/C1=C\c1ccc(-c2ccc(Cl)c(C(=O)O)c2)o1</smiles>

Scheme 21. Pyrazolones and related compounds.

GlaxoSmithKline introduced Eltrombopag (202) in 2008 as an antithrombocytopenic agent to treat ITP (idiopathic thrombocytopenic purpura), an autoimmune disease. ${ }^{195}$ The monastrol (a 
dihydrothiopyrimidine) enhancer $\mathbf{2 0 3}$ was discovered searching for novel anti-cancer agents. ${ }^{196}$ A HTS of more than 1 million compounds against the full-length NS5 protein resulted in the discovery of $\mathbf{2 0 4}$ a lead for the treatment of dengue viral illness. ${ }^{197}$ MUT11931 205 was a lead compound in a series of inhibitors of WaaC (a glycosyltransferase essential for inner core lipopolysaccharide biosynthesis) developed to eliminate antibiotic resistance. ${ }^{198}$

\subsection{Pyrazolines}

In this section there are several $N$-acyl derivatives $(\mathbf{2 0 6}, \mathbf{2 0 7}, \mathbf{2 0 8}, \mathbf{2 1 5}, 216$ and 217) that can be considered examples of Section 7.a. The fact that $N$-acylpyrazoles (only example 119) are rare while $N$-acylpyrazolines are common is related to the properties of azolides. ${ }^{199,200}$<smiles>Cc1ccc2[nH]c(=O)c(C3=NN(C(=O)CCC(=O)O)C(c4ccc(Br)cc4)C3)c(-c3ccccc3)c2c1</smiles><smiles>CC(C)C(N)C(=O)N1CC[C@@H](C#N)N1C(=O)Nc1cccc([N+](=O)[O-])c1</smiles>

208

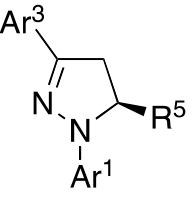<smiles>O=[N+]([O-])c1ccc(N2N=C(c3ccc(O)cc3)CC2c2ccc(F)cc2)cc1</smiles>

210

Cl<smiles>[R]c1ccc(S(=O)(=O)N([2H])C(=NO)N2C[C@H](c3ccccc3)C(c3ccc(I)cc3)=N2)cc1</smiles>

214, a, $\mathrm{R}=\mathrm{Cl}$ b, $\mathrm{R}=\mathrm{CF}_{3}$

\section{$\mathrm{HO}_{2} \mathrm{C}$}

207

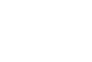

$\mathrm{HO}_{2} \mathrm{C}$

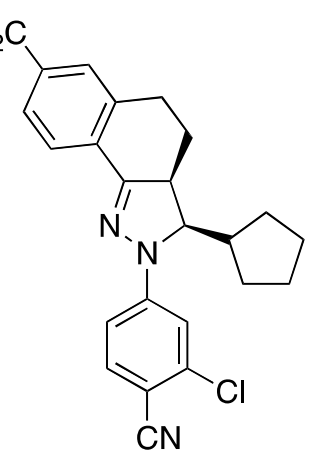

212
209 
Pyrazoline 206 bearing a quinolone substituent at position 3 acts on the glutamate receptors (GluN2C and GluN2D) and has potential for the treatment of Parkinson's disease. ${ }^{201}$ 5-Cyano-2pyrazoline $\mathbf{2 0 7}^{202}$ and 5-cyanopyrazolidine $\mathbf{2 0 8}^{203}$ were described as inhibitors of dipeptidyl peptidase 4 (DPP4) an ubiquitous serine protease that modulates the biological activity of glucagon-like peptide-1 (GLP-1). GLP-1 plays an important role in the control of glucose levels. GLP-1 has shown efficacy in diabetes, but suffers from a very short physiological half-life due to DPP4-mediated cleavage of the active peptide to an inactive form. A series of pyrazolines of general formula $209\left(\mathrm{R}^{5}=5\right.$-fluorophenyl or cyclopentyl, structures 210 to 213 ) possessing MR antagonist activity were developed for the treatment of hypertension. ${ }^{204,205}$ Compound 212 (PF3882845) was shown to decrease urinary albumin, reduce blood pressure and protect against kidney damage in rats. For these reasons it was chosen to advance in clinical studies for diabetic nephropathy.

Structurally distinct from the pyrazoles of section 4.c. is a series of 3,4-diarylpyrazolines. Based on in vitro and in vivo pharmacological data, (SLV-319 214) as well as its close analog (SLV326 215) were characterized as potent CB1 antagonists which displayed in vivo activity similar to rimonabant (104) in several pharmacological models. ${ }^{206,207}$ In the field of anticoagulant-antithrombotic agents, pyrazoline antagonists of PAR-1 (protease activated receptor), exemplified by pyrazoline $\mathbf{2 1 5}$ have been reported. ${ }^{208}$

Several pyrazolines have been published as anti-cancer agents. ${ }^{209-213}$ Compounds 216 and particularly 216d were identified as screening hits with ATPase IC $_{50}$ values of 3.6 and $6.9 \mathrm{mM}$, respectively. Exploration of N1-substitution with larger acyl or alkyl groups generally resulted in analogs with lower potency, whereas compound $\mathbf{2 1 7}$ with a dimethyl urea had similar potency to compound 216d. . $^{210}$

\section{Fluoro derivatives $\left(\mathrm{F}, \mathrm{CF}_{3}\right)$}
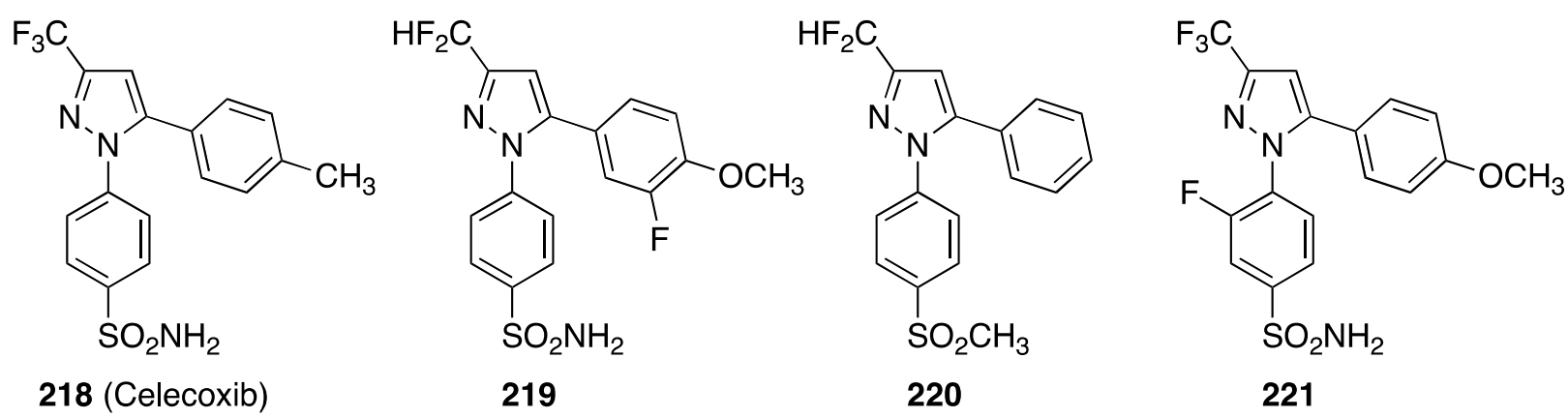

Scheme 23. Pyrazoles bearing $\mathrm{CF}_{3}$ or $\mathrm{CF}_{2} \mathrm{H}$ substituents.

Celebrex (Celecoxib) $\mathbf{2 1 8}$ is a pain drug known as a COX-2 selective non-steroidal antiinflammatory drug (NSAID) or a COX-2 inhibitor. Celebrex was widely prescribed to relieve arthritis and menstrual pain. Although Celebrex has been linked to an increased risk of heart 
attack and stroke, the risk associated with it is similar to the risk associated with the other nonselective NSAIDs, except aspirin. The number of references related to Celecoxib is very large; the interested reader can consult those reported in the $A R M C .^{214-217}$ For a recent review, see ref. $^{218}$

Another COX-2 inhibitor is Deracoxib (219), trade name Deramaxx (Novartis), used in veterinary medicine to treat osteoarthritis in dogs, in particular for the control of post operative pain and inflammation associated with orthopedic surgery. ${ }^{219}$ Selectivity COX-2/COX-1 has been considerably increased in pyrazole 220. ${ }^{220}$ Compound 221 had similar potency and selectivity to Celecoxib in enzyme assays. ${ }^{221}$

In the course of this review several compounds bearing $\mathrm{CF}_{3}$ substituents have been mentioned: 1, 4, 49, 50, 52, 58, 62, 63, 66, 68, 70, 71, 72, 73 and 74. These structures belong to Sections 3 (Heterocycles) and 4 (Amides). This observation is certainly significant, either $\mathrm{CF}_{3}$ groups in other sections have not led to interesting compounds, or it will be interesting to explore the effect of the $\mathrm{CF}_{3}$ (or $\mathrm{CF}_{2} \mathrm{H}$ ) substituents in the structures reported in Sections 5 to 13. On the other hand, directly fluorinated pyrazoles (C-fluoropyrazoles) have only one representative, compound 116. This is not because $\mathrm{F}$ is a less interesting substituent than $\mathrm{CF}_{3}$ but on account of the greater practical difficulty of making C-F pyrazoles, ${ }^{222-225}$ compared with the ease with which $\mathrm{C}-\mathrm{CF}_{3}$ pyrazoles can be prepared. .26-240 $^{2}$

\section{Conclusions}

When reading publications or attending lectures one is always surprised by the introductions where always the compounds under study have important applications, mainly in medicinal chemistry, to the point that it has been written that the most important pharmacophore is the phenyl ring because it is the most common feature in drugs. ${ }^{241}$ In the field of azoles, some of them are constituents of natural biomolecules: pyrrole (porphyrins, heme, chlorophyll, etc.), indole (tryptophan, serotonin, etc.), imidazole (histidine, histamine, etc.) and benzimidazole (vitamin $\mathrm{B}_{12}$ ); the remaining ones are xenobiotic. $1 H$-Tetrazoles have been used as carboxylic acid isosteres, 1,2,3-triazoles are less common but with the discovery of the click reactions their importance will increase. Pyrazoles and 1,2,4-triazoles are probably the most frequently found heterocyclic rings in medicinal chemistry although indazoles are becoming important.

The large number of pyrazoles [243 (taking into account that several include more than one structure) for the 2002-2012 period] reported in this review is but the tip of the iceberg. A conservative estimate is that the number of studied pyrazoles is 10 or 100 times larger, in the order of thousands.

When discussing toxicity it must be taken into account that this fact does not have the same relevance in the treatment of cancer as, for instance, in the treatment of high-blood pressure; or for a disease where several safe drugs already exist than, say, for an orphan drug (a pharmaceutical agent that has been developed specifically to treat a rare medical condition, the 
condition itself being referred to as a rare disease). However, that a very relevant drug with a pyrazole skeleton, Rimonabant (104) had to be withdrawn because of its psychiatric problems (depression) is not a good result concerning the safety of pyrazole derivatives. On the other hand, although Celebrex (Celecoxib) (218) has been associated with cardiovascular thrombotic (stroke) and gastrointestinal (perforation) events it continues to be a reference compound in the field of anti-inflammatory painkillers.

We hope that the present review will promote the use of the pyrazole scaffold and will show the type of structures that have been explored and, by exclusion, how many have not been used to explore their biological activities. Besides, some patterns appear relating the structure and the pharmacological field, this also should be considered when designing new pyrazoles in medicinal chemistry.

\section{Acknowledgements}

The present work has been supported by grants SAF2009-12422-C02-02 and RTA (RED Trastornos Adictivos RD06/001/0014).

\section{References}

1. Elguero, J.; Goya, P.; Jagerovic, N.; Silva, A. M. S. Targets in Heterocyclic Systems, Eds. Attanasi, O. A.; Spinelli, D. Italian Society of Chemistry, Rome, 2002, 6, 52. This review can be obtained from the authors (P.G. \& J.E.) on request.

2. Elguero, J.; Marzin, C.; Katritzky, A. R.; Linda, P. The Tautomerism of Heterocycles, Academic Press: New York, 1976.

3. Minkin, V. I.; Garnovskii, A. D.; Elguero, J.; Katritzky, A. R.; Denisko, O. V. Adv. Heterocycl. Chem. 2000, 76, 157. http://dx.doi.org/10.1016/S0065-2725(00)76005-3

4. Watson J. D. The Double Helix, a personal account of the discovery of the structure of DNA, Athenaeum, New York, 1968.

5. Elguero, J. "Elementary Dr. Watson", Struct. Chem. 2012, 23, 297. http://dx.doi.org/10.1007/s11224-011-9891-z

6. Schulz, D. W.; Mansbach, R. S.; Sprouse, J.; Braselton, J. P.; Collins, J.; Corman, M.; Dunaiskis, A.; Faraci, S.; Schmidt, A. W.; Seeger, T.; Seymour, P.; Tingley, F. D.; Winston, E. N.; Chen, Y. L.; Heyn, J. Proc. Natl. Acad. Sci. USA 1996, 93, 10477.

http://dx.doi.org/10.1073/pnas.93.19.10477

PMid:8816826 PMCid:PMC38410 
7. Kobayashi, K.; Uchiyama, M.; Ito, H.; Takahashi, H.; Yoshizumi, T.; Sakoh, H.; Nagatomi, Y.; Asai, M.; Miyazoe, H.; Tsujita, T.; Hirayama, M.; Ozaki, S.; Tani, T.; Ishii, Y.; Ohta, H.; Okamoto, O. Bioorg. Med. Chem. Lett. 2009, 19, 3627.

http://dx.doi.org/10.1016/j.bmcl.2009.04.116

PMid:19447610

8. Baxter, E. W.; Reitz, A. B. Annu. Rep. Med. Chem. 2005, 40, 44. http://dx.doi.org/10.1016/S0065-7743(05)40003-2

9. Quan, M. L.; Lam, P. Y. S.; Han, Q.; Pinto, D. J. P.; He, M. Y.; Li, R.; Ellis, C. D.; Clark, C. G.; Teleha, C. A.; Sun, J.-H.; Alexander, R. S.; Bai, S.; Luettgen, J. M.; Knabb, R. M.; Wong, P. C.; Wexler, R. R. J. Med. Chem. 2005, 48, 1729.

http://dx.doi.org/10.1021/jm0497949

PMid:15771420

10. Rabinowitz, M. H.; Barrett, T. D.; Rosen, M. D.; Venkatesa, H. Annu. Rep. Med. Chem. 2010, 45, 130.

http://dx.doi.org/10.1016/S0065-7743(10)45008-3

11. Warshakoon, N. C.; Wu, S.; Boyer, A.; Kawamoto, R.; Sheville, J.; Bhatt, R. T.; Renock, S.; Xu, K.; Pokross, M.; Zhou, S.; Walter, R.; Mekel, M.; Evdokimov, A. G.; East, S. Bioorg. Med. Chem. Lett. 2006, 16, 5616.

http://dx.doi.org/10.1016/j.bmcl.2006.08.026

PMid:16908149

12. Warshakoon, N. C.; Wu, S.; Boyer, A.; Kawamoto, R.; Renock, S.; Xu, K.; Pokross, M.; Evdokimov, A. G.; Zhou, S.; Winter, C.; Walter, R.; Mekel, M, Bioorg. Med. Chem. Lett. 2006, 16, 5687 .

http://dx.doi.org/10.1016/j.bmcl.2006.08.017

PMid:16908145

13. Rabinowitz, M. H.; Barrett, T. D.; Rosen, M. D.; Venkatesa, H. Annu. Rep. Med. Chem. 2010, 45, 135.

http://dx.doi.org/10.1016/S0065-7743(10)45008-3

14. Havrylyuk, D.; Zimenkovsky, B.; Vasylenko, O.; Gzella, A.; Lesyk, R. J. Med. Chem. 2012, 55,8630 .

http://dx.doi.org/10.1021/jm300789g

PMid:22992049

15. Hurt, C. R.; Lingappa, V. R.; Hansen, W. J. Annu. Rep. Med. Chem. 2011, 46, 287. http://dx.doi.org/10.1016/B978-0-12-386009-5.00010-2

16. Meanwell, N. A.; Kadow, J. F.; Scola, P. M. Annu. Rep. Med. Chem. 2009, 44, 409. http://dx.doi.org/10.1016/S0065-7743(09)04420-0

17. Wiener, J. J. M.; Gomez, L.; Venkatesan, H.; Santillán, Jr., A.; Allison, B. D.; Schwarz, K. L.; Shinde, S.; Tang, L.; Hack, M. D.; Morrow, B. J.; Motley, S. T.; Goldschmidt, R. M.; Shaw, K. J.; Jones, T. K.; Grice, C. A. Bioorg. Med. Chem. Lett. 2007, 17, 2718. 
http://dx.doi.org/10.1016/j.bmcl.2007.03.004

PMid:17382544

18. Aggarwal, R.; Sumran, G.; Garg, N.; Aggarwal, A. Eur. J. Med. Chem. 2011, 46, 3038.

http://dx.doi.org/10.1016/j.ejmech.2011.04.041

PMid:21558044

19. Carroll, F. I.; Howard, J. L.; Howell, L. L.; Fox, B. S.; Kuhar, M. J. AAPS J. 2006, 8, E196. http://dx.doi.org/10.1208/aapsj080124

PMid:16584128 PMCid:PMC2751440

20. Babu, R. P. K.; Maiti, S. N. Heterocycles 2006, 69, 539.

http://dx.doi.org/10.3987/REV-06-SR(O)1

21. Cowart, M.; Gfesser, G. A.; Browman, K. E.; Faghih, R.; Miller, T. R.; Milicic, I.; Baranowski, J. L.; Krueger, K. M.; Witte, D. G.; Molesky, A. L.; Komater, V. A.; Buckley, M. J.; Diaz, G. J.; Gagne, G. D.; Zhou, D.; Deng, X.; Pan, L.; Roberts, E. M.; Diehl, M. S.; Wetter, J. M.; Marsh, K. C.; Fox, G. B.; Brioni, J. D.; Esbenshade, T. A.; Hancock, A. A. Biochem. Pharmacol. 2007, 73, 1243.

http://dx.doi.org/10.1016/j.bcp.2007.02.010

PMid:17371699

22. Nugiel, D. A.; Krumrine, J. R.; Hill, D. C.; Damewod, J. R.; Bernstein, P. R.; SobotkaBriner, C. D.; Liu, J. W.; Zacco, A.; Pierson, M. E. J. Med. Chem. 2010, 53, 1876.

http://dx.doi.org/10.1021/jm901200t

PMid:20088516

23. Tu, Z.; Fan, J.; Li, S.; Jones, L. A.; Cui, J.; Padakanti, P. K.; Xu, J.; Zeng, D.; Shoghi, K. I.; Perlmutter, J. S.; Mach, R. H. Bioorg. Med. Chem. 2011, 19, 1666.

http://dx.doi.org/10.1016/j.bmc.2011.01.032

PMid:21315609 PMCid:PMC3056285

24. Plisson, C.; Salinas, C.; Weinzimmer, D.; Labaree, D.; Lin, S.-F.; Ding, Y.-S.; Jakobsen, S.; Smith, P. W.; Eiji, K.; Carlson, R. E.; Gunn, R. N.; Rabiner, E. A. Nucl. Med. Biol. 2011, 38, 875.

http://dx.doi.org/10.1016/j.nucmedbio.2011.02.005

PMid:21843784

25. Celen, S.; Koole, M.; De Angelis, M.; Sannen, I.; Chitneni, S. K.; Alcazar, J.; Dedeurwaerdere, S.; Moechars, D.; Schmidt, M.; Verbruggen, A.; Langlois, X.; Van Laere, K.; Andrés, J. I.; Bormans, G. J. Nucl. Med. 2010, 51, 1584.

26. Andrés, J. I.; De Angelis, M.; Alcázar, J.; Iturrino, L.; Langlois, X.; Dedeurwaerdere, S.; Lenaerts, I.; Vanhoof, G.; Celen, S.; Bormans, G. J. Med. Chem. 2011, 54, 5820.

http://dx.doi.org/10.1021/jm200536d

PMid:21777010

27. Neitz, R. J.; Konradi, A. W.; Sham, H. L.; Zmolek, W.; Wong, K.; Qin, A.; Lorentzen, C.; Nakamura, D.; Quinn, K. P.; Sauer, J.-M.; Powell, K.; Ruslim, L.; Chereau, D.; Ren, Z.; 
Anderson, J.; Bard, F.; Yednock, T. A.; Griswold-Prenner, I. Bioorg. Med. Chem. Lett. 2011, $21,3726$.

http://dx.doi.org/10.1016/j.bmcl.2011.04.074

PMid:21570836

28. Hong, S.-P.; Liu, K. G.; Ma, G.; Sabio, M.; Uberti, M. A.; Bacolod, M. D.; Peterson, J.; Zou, Z. Z.; Robichaud, A. J.; Doller, D. J. Med. Chem. 2011, 54, 5070.

http://dx.doi.org/10.1021/jm200290z

PMid:21688779

29. Aronov, A. M.; Baker, C.; Bemis, G. W.; Cao, J.; Chen, G.; Ford, P. J.; Germann, U. A.; Green, J.; Hale, M. R.; Jacobs, M.; Janetka, J. W.; Maltais, F.; Martínez-Botella, G.; Namchuk, M. N.; Straub, J.; Tang, Q.; Xie, X. J. Med. Chem. 2007, 50, 1280.

http://dx.doi.org/10.1021/jm061381f

PMid:17300186

30. Manthey, C. L.; Player, M. R. Annu. Rep. Med. Chem. 2009, 44, 219.

http://dx.doi.org/10.1016/S0065-7743(09)04410-8

31. Barth, F. Annu. Rep. Med. Chem. 2005, 40, 105. http://dx.doi.org/10.1016/S0065-7743(05)40007-X

32. Meinke, P. T.; Wood, H. B.; Szewczyk. J. W. Annu. Rep. Med. Chem. 2006, 41, 111.

33. Meinke, P. T.; Wood, H. B.; Szewczyk. J. W. Annu. Rep. Med. Chem. 2006, 41, 116.

34. Fyfe, M. C. T.; Overton, H. A.; Procter, M. J.; Reynet, C.; White, J. R. Annu. Rep. Med. Chem. 2007, 42, 140.

http://dx.doi.org/10.1016/S0065-7743(07)42009-7

35. Wydysh, E. A.; Medghalchi, S. M.; Vadlamudi, A.; Townnsend, C. A. J. Med. Chem. 2009, $52,3317$.

http://dx.doi.org/10.1021/jm900251a

PMid:19388675 PMCid:PMC3184552

36. Wu, M.; Singh, S. B.; Wang, J.; Chung, C. C.; Salituro, G.; Karanam, B. V.; Lee, S. H.; Powles, M.; Ellsworth, K. P.; Lassman, M. E.; Miller, C.; Myers, R. W.; Tota, M. R.; Zhang, B. B.; Li, C. Proc. Natl. Acad. Sci. U.S.A. 2011, 108, 5378.

http://dx.doi.org/10.1073/pnas.1002588108

http://dx.doi.org/10.1073/pnas.1114255108

http://dx.doi.org/10.1073/pnas.1108494108

http://dx.doi.org/10.1073/pnas.1104096108

http://dx.doi.org/10.1073/pnas.1009043108

http://dx.doi.org/10.1073/pnas.1100281108

http://dx.doi.org/10.1073/pnas.1117113108

http://dx.doi.org/10.1073/pnas.1105624108

http://dx.doi.org/10.1073/pnas.1110415108

http://dx.doi.org/10.1073/pnas.1103824108

http://dx.doi.org/10.1073/pnas.1118046108 
http://dx.doi.org/10.1073/pnas.1016693108

http://dx.doi.org/10.1073/pnas.1019732108

37. Oballa, R. M.; Belair, L.; Black, W. C.; Bleasby, K.; Chan, C. C.; Desroches, C.; Du, X.;

Gordon, R.; Guay, J.; Guiral, S.; Hafey, M. J.; Hamelin, E.; Huang, Z.; Kennedy, B.; Lachance, N.; Landry, F.; Li, C. S.; Mancini, J.; Normandin, D.; Pocai, A.; Powell, D. A.; Ramtohul, Y. K.; Skorey, K.; Sørensen, D.; Sturkenboom, W.; Styhler, A.; Waddleton, D. M.; Wang, H.; Wong, S.; Xu, L.; Zhang, L. J. Med. Chem. 2011, 54, 5082.

http://dx.doi.org/10.1021/jm200319u

PMid:21661758

38. Semple, G.; Skinner, P. J.; Gharbaoui, T.; Shin, Y.-J.; Jung, J.-K.; Cherrier, M. C.; Webb, P. J.; Tamura, S. Y.; Boatman, P. D.; R. Sage, C. R.; Schrader, T. O.; Chen, R.; letti, S. L.; Tata, J. R.; Waters, M. G.; Cheng, K.; Taggart, A. K.; Cai, T.-Q.; Carballo-Jane, E.; Behan, D. P.; Connolly, D. T.; Richman, J. G. J. Med. Chem. 2008, 51, 5101.

http://dx.doi.org/10.1021/jm800258p

PMid:18665582

39. Lai, E.; Waters, M. G.; Tata, J. R.; Radziszewski, W.; Perevozskaya, I.; Zheng, W.; Wenning, L.; Connolly, D. T.; Semple, G.; Johnson-Levonas, A. O.; Wagner, J. A.; Mithel, Y.; Paolini, F. J. Clin. Lipidol. 2008, 2, 375.

http://dx.doi.org/10.1016/j.jacl.2008.08.445

PMid:21291763

40. Shen, H. C.; Coletti, S. L. Annu. Rep. Med. Chem. 2010, 45, 88.

http://dx.doi.org/10.1016/S0065-7743(10)45005-8

41. Haydar, S. N.; Hirst, W. D. Annu. Rep. Med. Chem. 2006, 41, 48.

http://dx.doi.org/10.1016/S0065-7743(06)41003-4

42. Vijaykumar, D.; Sprengeler, P. A.; Shaghafi, M.; Spencer, J. R.; Katz, B. A.; Yu, C.; Rai, R.; Young, W. B.; Schultz, B.; Janc, J. Bioorg. Med. Chem. Lett. 2006, 16, 2796.

http://dx.doi.org/10.1016/j.bmcl.2006.01.123

PMid:16487703

43. Jorand-Lebrun, C.; Brondyk, B.; Lin, J.; Magar, S.; Murray, R.; Reddy, A.; Shroff, H.; Wands, G.; Weiser, W.; Xu, Q.; McKenna, S.; Brugger, N. Bioorg. Med. Chem. Lett. 2007, 17, 2080.

http://dx.doi.org/10.1016/j.bmcl.2006.12.062

PMid:17321742

44. Baraldi, P. G.; Tabrizi, M. A.; Preti, D.; Bovero, A.; Romagnoli, R.; Fruttarolo, F.; Zaid, N. A.; Moorman, A. R.; Varani, K.; Gessi, S.; Merighi, S.; Borea, P. A. J. Med. Chem. 2004, 47, 1434.

http://dx.doi.org/10.1021/jm0309654

PMid:14998332

45. Galatsis, P.; Wager, T. T.; offord, J.; DeMarco, G. J.; Ohren, J. F.; Efremov, I.; Mente, S. Annu. Rep. Med. Chem. 2011, 46, 99. 
46. Bronson, J.; Dhar, M.; Ewing, W.; Lonberg, N. Annu. Rep. Med. Chem. 2012, 47, 548. http://dx.doi.org/10.1016/B978-0-12-396492-2.00031-X

47. Bronson, J.; Dhar, M.; Ewing, W.; Lonberg, N. Annu. Rep. Med. Chem. 2012, 47, 525. http://dx.doi.org/10.1016/B978-0-12-396492-2.00031-X

48. Nuss, J. M.; Tsuhako, A. L.; Anand, N. K. Annu. Rep. Med. Chem. 2009, 44, 344. http://dx.doi.org/10.1016/S0065-7743(09)04417-0

49. Verstovsek, S.; Kantarjian, H.; Pardanani, A.; Thomas, D.; Cortes, J.; Mesa, R.; Hogan, W.; Redman, J.; Levy, R.; Vaddi, K.; Fridman, J.; Tefferi, A. Haematol. Hematol. J. 2008, 93 (suppl. 1), 179.

50. Ghosh, S.; Lobera, M.; Sundrud, M. S. Annu. Rep. Med. Chem. 2011, 46, 161. http://dx.doi.org/10.1016/B978-0-12-386009-5.00017-5

51. Edwards, M. P.; Price, D. A. Annu. Rep. Med. Chem. 2010, 45, 388. http://dx.doi.org/10.1016/S0065-7743(10)45023-X

52. Kinoshita, K.; Oikawa, N.; Tsukuda, T. Annu. Rep. Med. Chem. 2012, 47, 283. http://dx.doi.org/10.1016/B978-0-12-396492-2.00019-9

53. Blasina, A.; Hallin, J.; Chen, E.; Arango, M. E.; Kraynov, E.; Register, J.; Grant, S.; Ninkovic, S.; Chen, P.; Nichols, T.; O'Connor, P.; Anderes, K. Mol. Cancer. Ther. 2008, 7, 2394.

http://dx.doi.org/10.1158/1535-7163.MCT-07-2391

PMid:18723486

54. Dwyer, M. P.; Paruch, K.; Labroli, M.; Alvarez, C.; Keertikar, K. M.; Poker, C.; Rossman, R.; Fischmann, T. O.; Duca, J. S.; Madison, V.; Parry, D.; Davis, N.; Seghezzi, W.; Wiswell, D.; Guzi, T. J. Bioorg. Med. Chem. Lett. 2011, 21, 467.

http://dx.doi.org/10.1016/j.bmcl.2010.10.113 PMid:21094608

55. Labroli, M.; Paruch, K.; Dwyer, M. P.; Alvarez, C.; Keertikar, K. M.; Poker, C.; Rossman, R.; Duca, J. S.; Fischmann, T. O.; Madison, V.; Parry, D.; Davis, N.; Seghezzi, W.; Wiswell, D.; Guzi, T. J. Bioorg. Med. Chem. Lett. 2011, 21, 471.

http://dx.doi.org/10.1016/j.bmcl.2010.10.114 PMid:21094607

56. Tojo, M.; Hamashima, Y.; Hanyu, A.; Kajimoto, M.; Miyazono, K.; Node, M.; Imamura, T. Cancer Sci. 2005, 96, 791. http://dx.doi.org/10.1111/j.1349-7006.2005.00103.x PMid:16271073

57. Bavetsias, V.; Crumpler, S.; Sun, C.; Avery, S.; Atrash, B.; Faisal, A.; Moore, A. S.; Kosmopoulou, M.; Brown, N.; Sheldrake, P. W.; Busch, K.; Henley, A.; Box, G.; Valenti, M.; de Haven Brandon, A.; Raynaud, F. I.; Workman, P.; Eccles, S. A.; Bayliss, R.; Linardopoulos, S.; Blagg, J. J. Med. Chem. 2012, 55, 8721.

http://dx.doi.org/10.1021/jm300952s

PMid:23043539 PMCid:PMC3483018 
58. Mansour, T. S.; Agarwal, A.; Venkatesan, A. M.; Abe, T.; Mihira, A.; Takasaki, T.; Sato, K.; Ushirogochi, H.; Yamamura, I.; Isoda, T.; Li, Z.; Yang, Y.; Kumagai, T. Chem. Med. Chem. 2007, 2, 1713.

http://dx.doi.org/10.1002/cmdc.200700144

PMid:17868160

59. Bethel, C. R.; Distler, A. M.; Ruszczycky, M. W.; Carey, M. P.; Hujer, A. M.; Taracila, M.; Helfand, M. S.; Thomson, J. M.; Kalp, M.; Anderson, V. E.; Leonard, D. A.; Hujer, K. M.; Abe, T.; Venkatesan, A. M.; Mansour, T. S.; Bonomo, R. A. Antimicrob, Agents Chemother. 2008, 52, 267.

http://dx.doi.org/10.1128/AAC.01677-07

PMid:18559643 PMCid:PMC2533510

60. Blackie, J. A.; Bloomer, J. C.; Brown, M. J. B.; Cheng, H.-Y.; Elliot, R. L.; Hammond, B.; Hickey, D. M. B.; Ife, R. J.; Leach, C. A.; Lewis, V. A.; Macphee, C. H.; Milliner, K. J.; Moores, K. E.; Pinto, I. L.; Smith, S. A.; Stansfield, I. G.; Stanway, S. J.; Taylor, M. A.; Theobald, C. J.; Whittaker, C. M. Bioorg. Med. Chem. Lett. 2002, 12, 2603.

http://dx.doi.org/10.1016/S0960-894X(02)00473-0

61. Blackie, J. A.; Bloomer, J. C.; Brown, M. J. B.; Cheng, H.-Y.; Hammond, B.; Hickey, D. M. B.; Ife, R. J.; Leach, C. A.; Lewis, V. A.; Macphee, C. H.; Milliner, K. J.; Moores, K. E.; Pinto, I. L.; Smith, S. A.; Stansfield, I. G.; Stanway, S. J.; Taylor, M. A.; Theobald, C. J. Bioorg. Med. Chem. Lett. 2003, 13, 1067.

http://dx.doi.org/10.1016/S0960-894X(03)00058-1

62. Yang, J.; Gharagozloo, P.; Yao, J., Ilyin, V. I.; Carter, R. B.; Nguyen, P., Robledo, S., Woodward, R. M.; Hogenkamp, D. J. J. Med. Chem. 2004, 47, 1547.

http://dx.doi.org/10.1021/jm0497242

http://dx.doi.org/10.1021/jm030498q

PMid:14998340

63. Carson, K. G.; Jaffee, B. D.; Harriman, G. C. B. Annu. Rep. Med. Chem. 2004, 39, 152. http://dx.doi.org/10.1016/S0065-7743(04)39012-3

64. Heightman, T.D.; Gaster, L. M.; Pardoe, S. L.; Pilleux, J. P.; Hadley, M. S.; Middlemiss, D. N.; Price, G. W.; Roberts, C.; Scott, C. M.; Watson, J. M.; Gordon, L. J.; Holland, V. A.; Powles, J.; Riley, G. J.; Stean, T. O., Trail, B. K.; Upton, N.; Austin, N. E.; Ayrton, A. D.; Coleman, T.; Cutler, L. Bioorg. Med. Chem. Lett. 2005, 15, 4370.

http://dx.doi.org/10.1016/j.bmcl.2005.06.042

PMid:16039851

65. Clackers, M.; Coe, D. M.; Demaine, D. A.; Hardy, G. W.; Humphreys D.; Inglis, G. G. A.; Johnston, M. J.; Jones. H. T.; House, D.; Loiseau, R.; Minick, D. J.; Skone, P. A.; Uings, I.; McLay, I. M.; MacDonald, J. F. Bioorg. Med. Chem. Lett. 2007, 17, 4737.

http://dx.doi.org/10.1016/j.bmcl.2007.06.066

PMid:17616395

66. Han, S.; Thatte, J.; Jones, R. M. Annu. Rep. Med. Chem. 2009, 44, 240. 
http://dx.doi.org/10.1016/S0065-7743(09)04411-X

67. Dorange, I.; Swahn, B. -M. Annu. Rep. Med. Chem. 2011, 46, 59.

http://dx.doi.org/10.1016/B978-0-12-386009-5.00023-0

68. Célanire, S.; Duvey, G.; Poli, S.; Rocher, J. -P. Annu. Rep. Med. Chem. 2012, 47, 81.

http://dx.doi.org/10.1016/B978-0-12-396492-2.00006-0

69. Zia, Z. J.; Wu, Y.; Huang, W.; Clizbe, L. A.; Goldman, E. A.; Sinha, U.; Hutchaleelaha, A.;

Scarborough, R. M.; Zhu, B. Y. Bioorg. Med. Chem. Lett. 2004, 14, 1221.

http://dx.doi.org/10.1016/j.bmcl.2003.12.053

PMid:14980670

70. Zia, Z. J.; Wu, Y.; Huang, W.; Clizbe, L. A.; Goldman, E. A.; Sinha, U.; Woolfrey, J.; Hutchaleelaha, A.; Hollenbach, S. J.; Scarborough, R. M.; Zhu, B. Y Bioorg. Med. Chem. Lett. 2004, 14, 1229.

http://dx.doi.org/10.1016/j.bmcl.2003.12.054

PMid:14980671

71. Smallheer, J. M.; Alexander, R. S.; Wang, J.; Wang, S.; Nakajima, S.; Rossi, K. A.; Smallwood, A.; Barbera, F.; Burdick, D.; Luettgen, J. M.; Knabb, R. M.; Wexler R. R.; Jadhav, P. K. Bioorg. Med. Chem. Lett. 2004, 14, 5263.

http://dx.doi.org/10.1016/j.bmcl.2004.08.034

http://dx.doi.org/10.1016/j.bmcl.2003.10.057

PMid: 15454208

72. Bronson, J.; Dhar, M.; Ewing, W.; Lonberg, N. Annu. Rep. Med. Chem. 2012, 47, 509. http://dx.doi.org/10.1016/B978-0-12-396492-2.00031-X

73. Varnes, J. G.; Wacker, D. J.; Pinto, J. P.; Orwat, M. J.; Theroff, J. P.; Wells, B.; Galemo, R. A.; Luettgen, J. M.; Knabb, R. M.; Bai, S.; He, K.; Lam, P. Y. S.; Wexler, R. R. Bioorg. Med. Chem. Lett. 2008, 18, 749.

http://dx.doi.org/10.1016/j.bmcl.2007.11.040

PMid:18054227

74. Qiao, J. X.; Cheney, D. L.; Alexander, R. S.; Smallwood, A. M.; King, S. R.; He, K.; Rendina, A. R.; Luettgen, J. M.; Knabb, R. M.; Wexler, R. R.; Lam, P. Y. S. Bioorg. Med. Chem. Lett. 2008, 18, 4118.

http://dx.doi.org/10.1016/j.bmcl.2008.05.095

PMid: 18550370

75. Pinto, D. J. P.; Orwat, M. J.; Wang, S.; Fevig, J. M.; Quan, M. L.; Amparo, E.; Cacciola, J.; Rossi, K. A.; Alexander, R. S.; Smallwood, A. M.; Luettgen, J. M.; Liang, L.; Aungst, B. J.; Wright, M. R.; Knabb, R. M.; Wong, P. C.; Wexler, R. R.; Lam, P. Y. S. J. Med. Chem. 2001, 44, 566.

http://dx.doi.org/10.1021/jm000409z

76. Pinto, D. J. P.; Smallheer, J. M.; Cheney, D. L.; Knabb, R. M.; Wexler, R. R. J. Med. Chem. 2010, 53, 6243. 
http://dx.doi.org/10.1021/jm100146h

PMid:20503967

77. Zech, G.; Hessler, G.; Evers, A.; Weiss, T.; Florian, P.; Just, M.; Czech, J.; Czechtizky, W.; Görlitzer, J.; Ruf, S.; Kohlmann, M.; Nazaré, M. J. Med. Chem. 2012, 55, 8615.

http://dx.doi.org/10.1021/jm300771j

PMid:22984835

78. Barth, F. Annu. Rep. Med. Chem. 2005, 40, 104. http://dx.doi.org/10.1016/S0065-7743(05)40007-X

79. Hepworth, D.; Carpino, P. A.; Black, S. C. Annu. Rep. Med. Chem. 2006, 41, 79. http://dx.doi.org/10.1016/S0065-7743(06)41005-8

80. Hepworth, D.; Carpino, P. A.; Black, S. C. Annu. Rep. Med. Chem. 2006, 41, 80. http://dx.doi.org/10.1016/S0065-7743(06)41005-8

81. Chen, X.; Wilson, L. J.; Malaviya, R.; Argentieri, R. L.; Yang, S. J. Med. Chem. 2008, 51, 7015.

http://dx.doi.org/10.1021/jm070579c http://dx.doi.org/10.1021/jm801055h http://dx.doi.org/10.1021/jm701606b http://dx.doi.org/10.1021/jm8006454 http://dx.doi.org/10.1021/jm800662z http://dx.doi.org/10.1021/jm800471h http://dx.doi.org/10.1021/jm800167u http://dx.doi.org/10.1021/jm070578k PMid:18260619

82. Ghosh, S.; Lobera, M.; Sundrud, M. S. Annu. Rep. Med. Chem. 2011, 46, 162. http://dx.doi.org/10.1016/B978-0-12-386009-5.00017-5

83. Kim, S.; Henry, E. C.; Kim, D.; Kim, Y.; Shin, K. J.; Han, M. S.; Lee, T. G.; Gasiewicz, T. A.; Ryu, S. H.; Suh, P. Mol. Pharmacol. 2006, 69, 1871.

http://dx.doi.org/10.1124/mol.105.021048

http://dx.doi.org/10.1124/mol.105.020578

http://dx.doi.org/10.1124/mol.105.020487

http://dx.doi.org/10.1124/mol.105.021832

PMid:16540597

84. Kazmierski, W. M.; Gudmundsson, K. S.; Piscitelli, S. C. Annu. Rep. Med. Chem. 2007, 42, 310. http://dx.doi.org/10.1016/S0065-7743(07)42019-X

85. Meanwell, N. A.; Belema, M. Annu. Rep. Med. Chem. 2011, 46, 270. http://dx.doi.org/10.1016/B978-0-12-386009-5.00011-4

86. Wennerberg, M.; Cheng, L.; Hjorth, S.; Clapham, J. C.; Balendran, A.; Vauquelin, G. Fund. Clin. Pharmacol. 2011, 25, 200. 
http://dx.doi.org/10.1111/j.1472-8206.2010.00843.x

PMid:20608998

87. McInnes, C. Annu. Rep. Med. Chem. 2012, 47, 464.

http://dx.doi.org/10.1016/B978-0-12-396492-2.00029-1

88. Alvarado, M.; Goya, P.; Macías-González, M.; Pavón, F. J.; Serrano, A.; Jagerovic, N.; Elguero, J.; Gutiérrez-Rodríguez, A.; García-Granda, S.; Suardíaz, M.; Rodríguez de Fonseca, F. Bioorg. Med. Chem. 2008, 16, 10098.

http://dx.doi.org/10.1016/j.bmc.2008.10.023

PMid:18952442

89. Pérez-Fernández, R; Fresno, N; Macías, M; Elguero, J; Decara, J; Girón, R; RodríguezÁlvarez, A; Martín, M. I.; Rodríguez de Fonseca, F; Goya, P. ACS Med. Chem. Lett. 2011, 2 , 793.

90. Sato, N., Takahashi, T.; Shibata, T., Mashiko, S.; Haga, Y.; Sakuraba, A., Hirose, M.; Sato, K.; Nonoshita, K.; Koike, Y.; Kitazawa, H.; Fujino, N.; Ishi, Y.; Ishihara, A.; Kanatani, A.; Fukami, T. J. Med. Chem. 2003, 46, 666.

http://dx.doi.org/10.1021/jm025513q

PMid:12593644

91. Kinney,G. G.; O’Brien, J. A.; Lemaire, W.; Burno, M.; Bickel, D. J.; Clements, M. K.; Chen, T.-B.; Wisnoski, D. D.; Lindsley, C. W.; Tiller, P. R.; Smith, S.; Jacobson, M. A.; Sur, C.; Duggan, M. E.; Pettibone, D. J.; Conn, P. J.; Williams, D. L. J. Pharmacol. Exp. Ther. 2005, 313, 199.

http://dx.doi.org/10.1124/jpet.104.079244

PMid:15608073

92. Porter, J.; Payne, A.; de Candole, B.; Ford, D.; Hutchinson, B.; Trevitt, G.; Turner, J.; Edwards, C.; Watkins, C.; Whitcombe, I.; Davis, J.; Stufferfield, C. Bioorg. Med. Chem. Lett. 2009, 19, 230.

http://dx.doi.org/10.1016/j.bmcl.2009.01.071

http://dx.doi.org/10.1016/j.bmcl.2008.11.062

http://dx.doi.org/10.1016/j.bmcl.2008.10.113

http://dx.doi.org/10.1016/j.bmcl.2009.03.110

93. Tavares, F.X. ; Boncek, V.; Deaton, D. N.; Hassell, A. M.; Long, S. T. ; Miller, A. B.; Payne, A. A.; Miller, L. R.; Shewchuk, L. M.; Wells-Knecht, K.; Willard, Jr., D. H.; Wright L. L.; Zhou, H. Q. J. Med. Chem., 2004, 47, 588.

http://dx.doi.org/10.1021/jm040107n

http://dx.doi.org/10.1021/jm0400799

http://dx.doi.org/10.1021/jm0303731

http://dx.doi.org/10.1021/jm040063i

PMid:15341487 
94. Barrett, D. G.; Catalano, J. G.; Deaton, D. N.; Hassell, A. M.; Long, S. T.; Miller, A. B.; Miller, L. R.; Ray, J. A.; Samano, V.; Shewchuk, L. M.; Wells-Knecht, K. J.; Willard, Jr., D. H.; Wright, L. L. Bioorg. Med. Chem. Lett. 2006, 16, 1735.

http://dx.doi.org/10.1016/j.bmcl.2005.11.101

PMid:16376075

95. Barrett, D. G.; Boncek, V. M.; Catalano, J. G.; Deaton, D. N.; Hassell, A. M.; Jurgensen, C.; Long, S. T.; McFadyen, R. B.; Miller, A. B.; Miller, L. R.; Payne, J. A.; Ray, Samano, J. A.; Shewchuk, L. M.; Tavares, F.X.; Wells-Knecht, K.; D. H. Willard, Jr., D. H.; L. L. Wright L. L.; Zhou, Q. Bioorg. Med. Chem. Lett., 2005, 15, 3540.

http://dx.doi.org/10.1016/j.bmcl.2005.05.062

PMid: 15982880

96. Marx, I. E.; Di Mauro, E, F.; Cheng, A.; Emkey, R.; Hitchcock, S. A.; Huang, L.; Huang, M. Y.; Human, J.; Lee, J. H.; Li, X.; Martin, M. W.; White, R. D.; Fremeau, Jr., R. T.; Patel, V. F. Bioorg. Med. Chem. Lett. 2009, 19, 31.

http://dx.doi.org/10.1016/j.bmcl.2008.11.026

PMid:19062274

97. Verheijen, J.; Yu, K.; Zask, A. Annu. Rep. Med. Chem. 2008, 43, 197. http://dx.doi.org/10.1016/S0065-7743(08)00012-2

98. Wittman, M. D.; Velaparthi, U.; Vyas, D. M. Annu. Rep. Med. Chem. 2009, 44, 291. http://dx.doi.org/10.1016/S0065-7743(09)04414-5

99. Zobel, K.; Wang, L.; Varfolomeev, E.; Franklin, M. C.; Elliott, L. O.; Wallweber, H.J.; Okawa, D. C.; Flygare, J. A.; Vucic, D.; Fairbrother, W. J.; Deshayes, K. ACS Chem. Biol. 2006, 1, 525.

http://dx.doi.org/10.1021/cb6004195 http://dx.doi.org/10.1021/cb600387e http://dx.doi.org/10.1021/cb600276q PMid:17168540

100. Hamatake, R.; Maynard, A.; Kazmierski, M. Annu. Rep. Med. Chem. 2012, 47, 332. http://dx.doi.org/10.1016/B978-0-12-396492-2.00022-9

101. Fancelli, D.; Moll, J.; Varasi, M.; Bravo, R.; Artico, R.; Berta, D.; Bindi, S.; Cameron, A.; Candiani, I.; Cappella, P.; Carpinelli, P.; Croci, W.; Forte, B.; Giorgini, M. L.; Klapwijk, J.; Marsiglio, A.; Pesenti, E.; Rocchetti, M.; Roletto, F.; Severino, D.; Soncini, C.; Storici, P.; Tonani, R.; Zugnoni, P.; Vianello, P. J. Med. Chem. 2006, 49, 7247.

http://dx.doi.org/10.1021/jm060897w

PMid:17125279

102. Bossi, R. T.; Saccardo, M. B.; Ardini, E.; Menichincheri, M.; Rusconi, L.; Magnaghi, P.; Orsini, P.; Avanzi, N.; Borgia, A. L.; Nesi, M.; Bandiera, T.; Fogliatto, G.; Bertrand, J. A. Biochem. 2010, 49, 6813.

http://dx.doi.org/10.1021/bi1005514

PMid:20695522 
103. Yuan, Y.; Liao, Y.-M.; Hsueh, C.-T.; Mirshahidi, H. R. J. Hematol. Oncol. 2011, 4, 16. http://dx.doi.org/10.1186/1756-8722-4-16

PMid:21504625 PMCid:PMC3103487

104. Avendaño, C. An. Quim. 2012, 108, 1.

105. Rinaldi-Carmona, M.; Barth, F.; Heaulme, M.; Shire, D.; Calandra, B.; Congy, C.; Martinez, S.; Maruani, J.; Neliat, G.; Caput, D. FEBS Letters, 1994, 350, 240.

http://dx.doi.org/10.1016/0014-5793(94)00773-X

106. Hegde, S.; Schmidt, M. Annu. Rep. Med. Chem. 2007, 42, 537. http://dx.doi.org/10.1016/S0065-7743(07)42032-2

107. Jagerovic, N.; Fernández, C.; Goya, P. Curr. Top. Med. Chem. 2008, 8, 205. http://dx.doi.org/10.2174/156802608783498050 PMid:18289089

108. Wiley, J. L.; Jefferson, R. G.; Grier, M. C.; Mahadevan, M.; Kazdan, R. K.; Martin, B. R., J. Pharm. Exp. Ther. 2001, 296, 1013.

PMid:11181936

109. Gatley, S. J.; Lan, R,; Pyatt, B. A.; Gifford, A. N.; Volkow, N. D.; Makriyannis, A. Life Sci. 1997, 61, L191.

http://dx.doi.org/10.1016/S0024-3205(97)00690-5

110. Rinaldi-Carmona, M.; Barth, F.; Congy, C.; Martinez, S.; Oustric, D.; Perio, A.; Poncelet, M.; Maruani, J.; Arnone, M.; Finance, O.; Soubrie, P.; Le Fur, G. J. Pharmacol. Exp. Ther. 2004, 310, 905.

http://dx.doi.org/10.1124/jpet.104.067884

PMid:15131245

111. Shim, J.; Welsh, W. J.; Cartier, E.; Edwards, J. L.; Howlett, A. C. J. Med. Chem. 2002, $45,1447$.

http://dx.doi.org/10.1021/jm010267o

112. Stoit, A. R.; Lange, J. H.; Hartog, A. P.; Ronken, E.; Tipker, K.; Stuivenberg, H. H.; Dijksman, J. A.; Wals H. C.; Kruse, C .G. Chem. Pharm. Bull. 2002, 50, 1109. http://dx.doi.org/10.1248/cpb.50.1109

113. Ruiu, S.; Pinna, G. A.; Marchese, G.; Mussinu, J. M.; Saba, P.; Tambaro, S.; Casti, P.; Vargiu, R.; Pani, L. J. Pharmacol. Exp. Ther. 2003, 306, 363.

http://dx.doi.org/10.1124/jpet.103.049924

PMid:12663689

114. Pargellis, C.; Tong, L.; Churchill, L.; Cirillo, P. F.; Gilmore, T.; Graham, A. G.; Grob,P. M.; Hickey, E. R.; Moss, N.; Pav, S.; Regan, J. Nat. Struct. Biol. 2002, 9, 268.

http://dx.doi.org/10.1038/nsb770

PMid:11896401

115. Churruca, F.; Hernández, S.; Perea, M.; San Martín, R.; Domínguez, E. Chem. Comm. 2013, 49, 1413. 
http://dx.doi.org/10.1039/c2cc37905h

PMid:23320258

116. Card, G. L.; Blasdel, L.; England, B. P.; Zhang, C.; Suzuki, Y.; Gillette, S.; Fong, D.; Ibrahim, P. N.; Artis, D. R.; Bollag, G.; Milburn, M. V.; Kim, S. H.; Schlessinger, J.; Zhang, K. Y. Nat. Biotechnol. 2005, 23, 201.

http://dx.doi.org/10.1038/nbt1059

PMid:15685167

117. van Herk, T.; Brussee, J. A.; van den Nieuwendijk, M. C. H.; van der Klein, P. A. M.; Ijzerman, A. P.; Stannek, C.; Burmeister, A.; Lorenzen, A. J. Med. Chem. 2003, 46, 3945. http://dx.doi.org/10.1021/jm030888c

PMid:12930155

118. Sinclair, P. J. Annu. Rep. Med. Chem. 2005, 40, 73.

http://dx.doi.org/10.1016/S0065-7743(05)40005-6

119. Fyfe, M. C. T.; Overton, H. A.; Procter, M. J.; Reynet, C.; White, J. R. Annu. Rep. Med. Chem. 2007, 42, 140.

http://dx.doi.org/10.1016/S0065-7743(07)42009-7

120. Skinner, P. J.; Cherrier, M. C.; Webb, P. J.; Shin, Y. J.; Gharbaoui, T.; Lindstrom, A.; Hong, V.; Tamura, S. Y.; Dang, H. T.; Pride, C. C.; Chen, R.; Richman, J. G.; Connolly, D. T.; Semple, G. Bioorg. Med. Chem. Lett. 2007, 17, 5620.

http://dx.doi.org/10.1016/j.bmcl.2007.07.101

http://dx.doi.org/10.1016/j.bmcl.2007.09.058

121. Schmidt, D.; Smenton, A.; Raghavan, S.; Carballo-Jane, E.; Lubell, S.; Ciecko, T.; Holt,T. G.; Wolff, M.; Taggart, A.; Wilsie, L.; Kramanovic, M.; Ren, N.; Blom, D.; Cheng, K.; McCann, P. E.; Waters, M. G.; Tata, J.; Colletti, S. Bioorg. Med. Chem. Lett. 2009, 19, 4768 .

http://dx.doi.org/10.1016/j.bmcl.2009.06.054

PMid:19592242

122. Zecri, F. J.; Albert, R.; Landrum, G.; Hinterding, K.; Cooke, N. G.; Guerini, D.; Streiff, M.; Bruns, C.; Nuesslein-Hildesheim, B. Bioorg. Med. Chem. Lett. 2010, 20, 35.

http://dx.doi.org/10.1016/j.bmcl.2009.11.045

PMid:19954976

123. Medina, J. C.; Liu, J. Annu. Rep. Med. Chem. 2006, 41, 231.

http://dx.doi.org/10.1016/S0065-7743(06)41014-9

124. Bourbeau, M. P.; Allen, J. G.; Gu, W. Annu. Rep. Med. Chem. 2010, 45, 101.

http://dx.doi.org/10.1016/S0065-7743(10)45006-X

125. Carpino, P. A.; Hepworth, D. Annu. Rep. Med. Chem. 2012, 47, 188.

http://dx.doi.org/10.1016/B978-0-12-396492-2.00012-6

126. Marron, B. Annu. Rep. Med. Chem. 2006, 41, 69.

http://dx.doi.org/10.1016/S0065-7743(06)41004-6 
127. Kordik, C. P.; Luo, C.; Zanoni, B. C.; Dax, S. L.; McNally, J. J.; Lovenberg, T. W.; Wilson, S. J.; Reitz, A. B. Bioorg. Med. Chem. Lett. 2001, 11, 2283.

http://dx.doi.org/10.1016/S0960-894X(01)00448-6

http://dx.doi.org/10.1016/S0960-894X(01)00449-8

128. Lloyd, J.; Finlay, H. J.; Atwal, K.; Kover, A.; Prol, J.; Yan, L.; Bhandaru, R.; Vaccaro, W.; Huynh, T.; Huang, C. S.; Conder, M. L.; Jenkins-West, T.; Sun, H.; Li, D.; Levesque, P. Bioorg. Med. Chem. Lett. 2009, 19, 5469.

http://dx.doi.org/10.1016/j.bmcl.2009.07.083

PMid:19665893

129. Krystof, V.; Cankar, P.; Frysová, I.; Slouka, J.; Kontopidis,| G.; Dzubák, P.; Hajdúch, M.; Srovnal, J.; Azevedo Jr., W. F.; Orság, M.; Paprskárová, M.; Rolcík, J.; Látr, A.; Fischer, P. M.; Strnad, M. J. Med. Chem. 2006, 49, 6500.

PMid:17064068

130. Wittman, M. D.; Velaparthi, U.; Vyas, D. M. Annu. Rep. Med. Chem. 2009, 44, 287. http://dx.doi.org/10.1016/S0065-7743(09)04414-5

131. Wittman, M. D.; Carboni, J. M.; Yang, Z.; Lee, F. Y.; Antman, M.; Attar, R.; Balimane, P.; Chang, C.; Discenza, L.; Frennesson, D.; Gottardis, M. M.; Greerm A.; Hurlburt, W.; Johnson, W.; Langley, D. R.; Li, A.; Li, J.; Liu, P.; Mastalerz, H.; Methur, A.; Menard, K.; Patel, K.; Sack, J.; Sang, X.; Saulnier, M.; Smith, D.; Stefanski, K.; Trainor, G.; Velaparthi, U.; Zhang, G.; Zimmermann, K.; Vyas, D. M. J. Med. Chem. 2009, 52, 7360.

http://dx.doi.org/10.1021/jm900786r

PMid:19778024

132. Wittman, M. D.; Velaparthi, U.; Vyas, D. M. Annu. Rep. Med. Chem. 2009, 44, 289. http://dx.doi.org/10.1016/S0065-7743(09)04414-5

133. Hedvat, M.; Huszar, D.; Herrmann, A.; Gozgit, J. M.; Schroeder, A.; Sheehy, A.; Buettner, R.; Proia, D.; Kowolik, C. M.; Xin, H.; Armstrong, B.; Bebernitz, G.; Weng, S.; Wang, L.; Ye, M.; McEachern, K.; Chen, H.; Morosini, D.; Bell, K.; Alimzhanov, M.; Ioannidis, S.; McCoon, P.; Cao, Z. A.; Yu, H.; Jove, R.; Zinda, M. Cancer Cell 2009, 16, 487.

http://dx.doi.org/10.1016/i.ccr.2009.10.015

PMid:19962667 PMCid:PMC2812011

134. Gozgit, J. M.; Bebernitz, G.; Patil, P.; Ye, M.; Parmentier, J.; Wu, J.; Su, N.; Wang, T.; Ioannidis, S.; Davies, A.; Huszar, D.; Zinda, M. J. Biol. Chem. 2008, 283, 32334.

http://dx.doi.org/10.1074/jbc.M803813200

PMid:18775810

135. Ioannidis, S.; Lamb, M. L.; Davies, A. M.; Almeida, L.; Su, M.; Bebernitz, G.; Ye, M.; Bell, K.; Alimzhanov, M.; Zinda, M. Bioorg. Med. Chem. Lett. 2009, 19, 6524.

http://dx.doi.org/10.1016/j.bmcl.2009.10.054

PMid:19857966

136. Meanwell, N. A. Annu. Rep. Med. Chem. 2008, 43, 397. 
http://dx.doi.org/10.1016/S0065-7743(08)00022-5

137. Wang, T.; Lamb, M. L.; Scott, D. A.; Wang, H.; Block, M. H.; Lyne, P. D.; Lee, J. W.; Davies, A. M.; Zhang, H.; Zhu, Y.; Gu, F.; Han, Y.; Wang, B.; Mohr, P. J.; Kaus, R. J.; Josey, J. A.; Hoffmann, E.; Thress, K.; MacIntyre, T.; Wang, H.; Omer, C. A.; Yu, D. J. Med. Chem. 2008, 51, 4672.

http://dx.doi.org/10.1021/jm8005788

http://dx.doi.org/10.1021/jm701519h

http://dx.doi.org/10.1021/jm800343j

PMid: 18646745

138. Thress, K.; MacIntyre, T.; Wang, H.; Whitson, D.; Liu, Z. Y.; Hoffmann, E.; Wang, T.; Brown, J. L.; Webster, K.; Omer, C.; Zage, P. E.; Zeng, L.; Zweidler-McKay, P. A. Mol. Cancer Ther. 2009, 8, 1818.

http://dx.doi.org/10.1158/1535-7163.MCT-09-0036

PMid:19509272

139. Li, Z.; Umeyama, T.; Wang, C. C. PLoS Pathog. 2009, 5, e1000575.

http://dx.doi.org/10.1371/journal.ppat.1000537

http://dx.doi.org/10.1371/journal.ppat.1000707

http://dx.doi.org/10.1371/journal.ppat.1000575

PMid:19750216 PMCid:PMC2734176

140. Bevan, D. E.; Martinko, A. J.; Loram, L. C.; Stahl, J. A.; Taylor, F. R.; Joshee, S.; Watkins, L. R.; Yin, H. ACS Med. Chem. Lett. 2010, 1, 194.

141. Frechette, R. Annu. Rep. Med. Chem. 2007, 42, 355.

http://dx.doi.org/10.1016/S0065-7743(07)42022-X

142. Burgess, L. E. Annu. Rep. Med. Chem. 2011, 46, 126.

http://dx.doi.org/10.1016/B978-0-12-386009-5.00019-9

143. Shen, H. C.; Colletti, S. L. Annu. Rep. Med. Chem. 2010, 45, 84.

http://dx.doi.org/10.1016/S0065-7743(10)45005-8

144. Meinke, P. T.; Wood, H. B.; Szewczyk, J. W. Annu. Rep. Med. Chem. 2006, 41, 115.

http://dx.doi.org/10.1016/S0065-7743(06)41006-X

145. Semple, G.; Fioravanti, B.; Pereira, G.; Calderon, I.; Uy, J.; Choi, K.; Xiong, Y.; Ren, A.; Morgan, M.; Dave, V.; Thomsen, W.; Unett, D. J.; Xing, C.; Bossie, S.; Carroll, C.; Chu, Z. L.; Grottick, A. J.; Hauser, E. K.; Leonard, J. N.; Jones, R. M. J. Med. Chem. 2008, 51, 5172. http://dx.doi.org/10.1021/jm8006867

http://dx.doi.org/10.1021/jm800258p

PMid:18665582

146. Chu, Z.-L.; Jones, R. M.; He, H.; Carroll, C.; Gutierrez, V.; Lucman, A.; Moloney, M.; Gao, H.; Mondala, H.; Bagnol, D.; Unett, D.; Liang, Y.; Demarest, K.; Semple, G.; Behan, D. P.; Leonard, J. Endocrinology, 2007, 148, 2601.

http://dx.doi.org/10.1210/en.2006-1608

PMid:17289847 
147. Washburn, W. N. J. Med. Chem. 2009, 52, 1785.

http://dx.doi.org/10.1021/jm8013019

PMid:19243175

148. Pinkerton, A. B.; Huang, D.; Cube, R. V.; Hutchinson, J. H.; Struthers, M.; Ayala, J. M.; Vicario,P. P.; Patel, S. R.; Wisniewski, T.; DeMartino, J. A.; Vernier, J.-M. Bioorg. Med. Chem. Lett. 2007, 17, 807.

http://dx.doi.org/10.1016/j.bmcl.2006.10.060

http://dx.doi.org/10.1016/j.bmcl.2007.04.076

149. Osborne, R.; Clark, N.; Glossop, P.; Kenyon, A.; Liu, H.; Patel, S.; Summerhill, S.; Jones, L. H. J. Med. Chem. 2011, 54, 6998.

http://dx.doi.org/10.1021/jm2007535

PMid:21863888

150. Barbey, S.; Goossens, L.; Taverne, T.; Cornet, J.; Choesmel, V.; Rouaud, C.; Gimeno, G.; Yannic-Arnoult, S.; Michaux, C.; Charlier, C.; Houssin, R.; Hénichart, J.-P. Bioorg. Med. Chem. Lett. 2002, 12, 779.

http://dx.doi.org/10.1016/S0960-894X(02)00013-6

151. Pommery, N.; Taverne, T.; Telliez, A.; Goossens, L.; Charlier, C.; Pommery, J.; Goossens, J.-F.; Houssin, R.; Durant, F.; Hénichart, J.-P. J. Med. Chem. 2004, 47, 6195.

http://dx.doi.org/10.1021/jm0407761

PMid:15566290

152. Nantermet, P. G.; Henze, D. A. Annu. Rep. Med. Chem. 2011, 46, 29.

http://dx.doi.org/10.1016/B978-0-12-386009-5.00025-4

153. Charlier, C.; Michaux, C. Eur. J. Med. Chem. 2003, 38, 645.

http://dx.doi.org/10.1016/S0223-5234(03)00115-6

154. Connolly, P. J.; Wetter, S. K.; Beers, K. N.; Hamel, S. C.; Chen, R. H. K.; Wachter, M. P.; Ansell, J.; Singer, M. M.; Steber, M.; Ritchie, D. M.; Argentieri, D. C. Bioorg. Med. Chem. Lett. 1999, 9, 979.

http://dx.doi.org/10.1016/S0960-894X(99)00117-1

155. Horizoe, T.; Nagakura, N.; Chiba, K.; Shirota, H.; Shinoda, M.; Kobayashi, N.; Numata, H.; Okamoto, Y.; Kobayashi,S. Inflamm. Res. 1998, 47, 375.

http://dx.doi.org/10.1007/s000110050347

PMid:9831321

156. Friesen, R. W.; Riendeau, D. Annu. Rep. Med. Chem. 2005, 40, 208.

http://dx.doi.org/10.1016/S0065-7743(05)40013-5

157. Manning, M.; Stoev, S.; Chini, B.; Durroux, T.; B.Mouillac, Guillon, G. Prog. Brain Res. 2008, 170, 473.

http://dx.doi.org/10.1016/S0079-6123(08)00437-8

158. Shen, H. C.; Ding, F. X.; Deng, Q.; Wilsie, L. C.; Krsmanovic, M. L.; Taggart, A. K.; Carballo-Jane, E.; Ren, N.; Cai, E. T.; Wu, T. J.; Wu, K. K.; Cheng, K.; Chen, Q.; Wolff, M. 
S.; Tong, X.; Holt, T. G.; Waters, M. G.; Hammond, M. L.; Tata, J. R.; Colletti, S. L. J. Med. Chem. 2009, 52, 2587.

http://dx.doi.org/10.1021/jm900151e

http://dx.doi.org/10.1021/jm900725r

PMid:19645482

159. Shen, H. C.; Colletti, S. L. Annu. Rep. Med. Chem. 2010, 45, 82.

http://dx.doi.org/10.1016/S0065-7743(10)45005-8

160. Hughes, R. O.; Bartolozzi, A.; Takahashi, H. Annu. Rep. Med. Chem. 2012, 47, 228.

http://dx.doi.org/10.1016/B978-0-12-396492-2.00015-1

161. Stauffer, S. R.; Huang, Y. R.; Aron, Z. D.; Coletta, C. J.; Sun, J.; Katzenellenbogen, B.

S.; Katzenellenbogen, J. A. Bioorg. Med. Chem. 2001, 9, 151.

http://dx.doi.org/10.1016/S0968-0896(00)00226-1

http://dx.doi.org/10.1016/S0968-0896(00)00228-5

162. Suino-Powell, K.; Xu, Y.; Zhang, C.; Tao, Y. G.; Tolbert, W. D.; Simons, S. S. Jr.; Xu, H. E. Mol. Cell. Biol. 2008, 28, 1915.

http://dx.doi.org/10.1128/MCB.01541-07

PMid:18160712 PMCid:PMC2268401

163. Ali, A.; Thompson, C. F.; Balkovec, J. M.; Graham, D. W.; Hammond, M. L.; Quraishi, N.; Tata, J. R.; Einstein, M.; Ge, L.; Harris, G.; Kelly, T. M.; Mazur, P.; Pandit, S.; Santoro, J.;. Sitlani, A.; Wang, C.; Williamson, J.; Miller, D. K.; Thompson, C. M.; Zaller, D. M.; Forrest, M. J.; Carballo-Jane, E.; Luell, S. J. Med. Chem. 2004, 47, 2441.

http://dx.doi.org/10.1021/jm030585i

PMid:15115388

164. Thompson, C. F.; Quraishi, N.; Ali, A.; Tata, J. R.; Hammond, M. L.; Balkovec, J. M.; Einstein, M.; Ge, L.; Harris, G.; Kelly, T. M.; Mazur, P.; Pandit, S.; Santoro, J.; Sitlani, A.; Wang, C.; Williamson, J.; Miller, D. K.; Yamin, T. T.; Thompson, C. M.; O’Neill, E. A.; Zaller, D.; Forrest, M. J.; Carballo-Jane, E.; Luell, S. Bioorg. Med. Chem. Lett. 2005, 15 , 2163.

http://dx.doi.org/10.1016/j.bmcl.2005.02.009

PMid:15808489

165. Thompson, C. F.; Quraishi, N.; Ali, A.; Mosley, R. T.; Tata, J. R.; Hammond, M. L.; Balkovec, J. M.; Einstein, M.; Ge, L.; Harris, G.; Kelly, T. M.; Mazur, P.; Pandit, S.; Santoro, J.; Sitlani, A.; Wang, C.; Williamson, J.; Miller, D. K.; Yamin, T. T.; Thompson, C. M.; O’Neill, E. A.; Zaller, D.; Forrest, M. J.; Carballo-Jane, E.; Luell, S. Bioorg. Med. Chem. Lett. 2007, 17, 3354.

http://dx.doi.org/10.1016/j.bmcl.2007.03.103

PMid:17467988

166. Smith, C. J.; Ali, A.; Balkovec, J. M.; Graham, D. W.; Hammond, M. L.; Patel, G. F.; Rouen, G. P.; Smith, S. K.; Tata, J. R.; Einstein, M.; Ge, L.; Harris, G. S.; Kelly, T. M.; Mazur, P.; Thompson, C. M.; Wang, C. F.; Williamson, J. M.; Miller, D. K.; Pandit, S.; 
Santoro, J. C.; Sitlani, A.; Yamin, T. T.; O’Neill, E. A.; Zaller, D. M.; Carballo-Jane, E.; Forrest, M. J.; Luell, S. Bioorg. Med. Chem. Lett. 2005, 15, 2926.

http://dx.doi.org/10.1016/j.bmcl.2005.03.027

http://dx.doi.org/10.1016/j.bmcl.2005.05.068

http://dx.doi.org/10.1016/j.bmcl.2005.05.002

http://dx.doi.org/10.1016/j.bmcl.2004.12.080

167. Shah, N.; Scanlan, T. S. Bioorg. Med. Chem. Lett. 2004, 14, 5199.

http://dx.doi.org/10.1016/j.bmcl.2004.07.052

PMid:15380227

168. Wang, J. C.; Shah, N.; Pantoja, C.; Meijsing, S. H.; Ho, J. D.; Scanlan, T. S.; Yamamoto, K. R. Genes Dev. 2006, 20, 689.

http://dx.doi.org/10.1101/gad.1400506

http://dx.doi.org/10.1101/gad.388406

http://dx.doi.org/10.1101/gad.1487506

http://dx.doi.org/10.1101/gad.1393506

169. DeMong, D. E.; Miller, M. W.; Lachowicz, J. E. Annu. Rep. Med. Chem. 2008, 43, 131. http://dx.doi.org/10.1016/S0065-7743(08)00008-0

170. Shen, D.-M.; Brady, E. J.; Candelore, M. R.; Dallas-Yang, Q.; Ding, V. D. -H.; Feeney, W. P.; Jiang, G.; McCann, M. E.; Mock, S.; Qureshi, S. A.; Saperstein, R.; Shen, X.; Tong, X.; Tota, L. M.; Wright, M. J.; Yang, X.; Zheng, S.; Chapman, K. T.; Zhang, B. B.; Tata, J. R.; Parmee, E. R. Bioorg. Med. Chem. Lett. 2011, 21, 76.

http://dx.doi.org/10.1016/j.bmcl.2011.01.090

http://dx.doi.org/10.1016/j.bmcl.2010.11.074

PMid:21147532

171. Choi, K. H.; Rossmann, M. G. Curr. Opin. Struct. Biol. 2009, 19, 746.

http://dx.doi.org/10.1016/j.sbi.2009.10.015

PMid:19914821

172. Nantermet, P. G.; Henze, D. A. Annu. Rep. Med. Chem. 2011, 46, 24.

http://dx.doi.org/10.1016/B978-0-12-386009-5.00025-4

173. Braisted, A. C.; Oslob, J. D.; Delano, W. L.; Hyde, J.; McDowell, R. S.; Waal, N.; Yu, C.; Arkin, M. R.; Raimundo, B. C. J. Am. Chem. Soc. 2003, 125, 3714.

http://dx.doi.org/10.1021/ja034247i

PMid:12656598

174. Gustin, D. J.; Sehon, C. A.; Wei, J.; Cai, H.; Meduna, S. P.; Khatuya, H.; Sun, S.; Gu, Y.; Jiang, W.; Thurmond, R. L.; Karlsson, L.; Edwards, J. P. Bioorg. Med. Chem. Lett. 2005, 15 , 1687.

http://dx.doi.org/10.1016/j.bmcl.2005.01.045

PMid:15745822

175. Wei, J.; Pio, B. A.; Cai, H.; Meduna, S. P.; Sun, S.; Gu, Y.; Jiang, W.; Thurmond, R. L.; Karlsson, L.; Edwards, J. P. Bioorg. Med. Chem. Lett. 2007, 17, 5525. 
http://dx.doi.org/10.1016/j.bmcl.2007.08.038

http://dx.doi.org/10.1016/j.bmcl.2007.02.053

http://dx.doi.org/10.1016/j.bmcl.2006.09.052

176. Boyle, C. D.; Kowalski, T. J.; Zhang, L. Annu. Rep. Med. Chem. 2006, 41, 133.

http://dx.doi.org/10.1016/S0065-7743(06)41007-1

177. Bourbeau, M. P.; Allen, J. G.; Gu, W. Annu. Rep. Med. Chem. 2010, 45, 99.

http://dx.doi.org/10.1016/S0065-7743(10)45006-X

178. Van Goor, F.; Strayley, K. S.; Cao, D.; González, J.; Hadida, S.; Hazlewood, A.; Joubran, J.; Knapp, T.; Lewis, L. R.; Miller, M.; Neuberger, T.; Olson, E.; Pachenko, V.; Rader, J.; Singh, A.; Stack, J. H.; Tung, R.; Grootenhuis, P. D. J.; Negulescu, P. Am. J. Physiol. Lung Cell Mol. Physiol. 2006, 290, L1117.

http://dx.doi.org/10.1152/ajplung.00169.2005

PMid:16443646

179. Rowlands, M. G.; Newbatt, Y. M.; Prodromou, C.; Pearl, L. H.; Workman, P.; Aherne, P. Anal. Biochem. 2004, 327, 176.

http://dx.doi.org/10.1016/j.ab.2003.10.038

PMid:15051534

180. Heerding, D. A.; Safonov, I. G.; Verma, S. K. Annu. Rep. Med. Chem. 2007, 42, 368.

http://dx.doi.org/10.1016/S0065-7743(07)42023-1

181. Saxty, G.; Woodhead, S. J.; Berdini, V.; Davies, T. G.; Verdonk, M. L.; Wyatt, P. G.; Boyle, R. G.; Barford, D.; Downham, R.; Garrett, M. D.; Carr, R. A. J. Med. Chem. 2007, 50, 2293.

http://dx.doi.org/10.1021/jm070091b

PMid:17451234

182. Meanwell, N. A.; Kadow, J. F.; Scola, P. M. Annu. Rep. Med. Chem. 2009, 44, 411. http://dx.doi.org/10.1016/S0065-7743(09)04420-0

183. Luscombe, C. A.; Huang, Z.; Murray, M. G.; Miller, M.; Wilkinson, J.; Ewart, G. D. Antiviral Res. 2010, 86, 144.

http://dx.doi.org/10.1016/j.antiviral.2010.02.312

PMid:20156486

184. Khoury, G.; Ewart, G.; Luscombe, C.; Miller, M.; Wilkinson, J. Antimicrob. Agents Chemother. 2010, 54, 835.

http://dx.doi.org/10.1128/AAC.01308-09

PMid:19995924 PMCid:PMC2812169

185. Fader, L. D.; Bethell, R.; Bonneau, P.; Bos, M.; Bousquet, Y.; Cordingley, M. G.; Coulombe, R.; Derby, P.; Faucher, A. M.; Gagnon, A.; Goudreau, N.; Maitre, C. G.; Guse, I.; Hucke, O.; Kawai, S. H.; Lacoste, J. E.; Landry, S.; Lemke, C. T.; Malenfant, E.; Mason, S.; Morin, S.; O’Meara, J.; Simoneau, B.; Titolo, S.; Yoakim,C. Bioorg. Med. Chem. Lett. 2011, 21,398 . 
http://dx.doi.org/10.1016/j.bmcl.2010.10.131

PMid:21087861

186. Velaparthi, U.: Wittman, M.; Liu, P.; Carboni, J. M.; Lee, F. Y.; Attar, R.; Balimane, P.; Clarke, W.; Sinz, M. W.; Hulburt, W.; Patel. K.; Discenza, L.; Kim, S.; Gottardis, M.; Greer, A.; Li, A.; Saulnier, M.; Yang, Z.; Zimmermann, K.; Trianor, G.; Vyas, D. J. Med. Chem. 2008, 51, 5897.

http://dx.doi.org/10.1021/jm800832q

PMid:18763755

187. Chaulagain, M. R.; Aron, Z. D. J. Org. Chem. 2010, 75, 8271.

http://dx.doi.org/10.1021/jo101304q

PMid:21033730

188. Mayhoub, A. S. Bioorg. Med. Chem. 2012, 20, 3150.

http://dx.doi.org/10.1016/j.bmc.2011.09.031

http://dx.doi.org/10.1016/j.bmc.2012.10.006

http://dx.doi.org/10.1016/j.bmc.2012.01.047

http://dx.doi.org/10.1016/j.bmc.2012.03.049

PMid:22516671

189. Bernardelli, P.; Gaudillière, B.; Vergne, F. Annu. Rep. Med. Chem. 2002, 37, 265.

http://dx.doi.org/10.1016/S0065-7743(02)37027-1

190. Scarborough, R. M.; Pandey, A.; Zhang, X. Annu. Rep. Med. Chem. 2005, 40, 95.

http://dx.doi.org/10.1016/S0065-7743(05)40006-8

191. Khojasteh-Bakht, S. C.; O'donnell, J. P.; Fouda, H. G.; Potchoiba, M. J. Drug Metab.

Dispos. 2005, 33, 190.

http://dx.doi.org/10.1124/dmd.104.001065

PMid:15486077

192. Carpino P. A.; Lefker, B. A.; Toler, S. M.; Pan, L. C.; Hadcock, J. R.; Murray, M. C.; Cook, E. R.; DiBrino, J. N.; DeNinno, S. L.; Chidsey-Frink, K. L.; Hada, W. A.; Inthavongsay, J.; Lewis, S. K.; Mangano, F. M.; Mullins, M. A.; Nickerson, D. F.; Ng, O.; Pirie, C. M.; Ragan, J. A.; Rose, C. R.; Tess, D. A.; Wright, A. S.; Yu, L, Zawistoski, M. P.; Pettersen, J. C.; DaSilva-Jardine, P. A.; Wilson, T. C.; Thompson, D. D. Bioorg. Med. Chem. Lett. 2002, 12, 3279.

http://dx.doi.org/10.1016/S0960-894X(02)00734-5

193. Carpino, P. A.; Lefker, B. A.; Toler, S. M.; Pan, L. C.; Hadcock, J. R.; Cook, E. R.; DiBrino, J. N.; Campeta, A. M.; DeNinno, S. L.; Chidsey-Frink, K. L.; Hada, W. A.; Inthavongsay, J.; Mangano, F. M.; Mullins, M. A.; Nickerson, D. F.; Ng, O.; Pirie, C. M.; Ragan, J. A.; Rose, C. R.; Tess, D. A.; Wright, A. S.; Yu, L.; Zawistoski, M. P.; DaSilvaJardine, P. A.; Wilson, T. C.; Thompson, D. D. Bioorg. Med. Chem. 2003, 11, 581.

http://dx.doi.org/10.1016/S0968-0896(02)00433-9

194. Pan, L. C.; Carpino, P. A.; Lefker, B. A.; Ragan, J. A.; Toler, S. M.; Pettersen, J. C.; Nettleton, D. O.; Ng, O.; Pirie, C. M.; Chidsey-Frink, K.; Lu, B.; Nickerson, D. F.; Tess, D. 
A.; Mullins, M. A.; MacLean, D. B.; DaSilva-Jardine, P. A.; Thompson, D. D. Endocrine. 2001, 14, 121.

http://dx.doi.org/10.1385/ENDO:14:1:121

195. Hegde, S.; Schmidt, M. Annu. Rep. Med. Chem. 2010, 45, 497.

http://dx.doi.org/10.1016/S0065-7743(10)45028-9

196. Wood, K. W.; Bergnes, G. Annu. Rep. Med. Chem. 2004, 39, 180.

http://dx.doi.org/10.1016/S0065-7743(04)39014-7

197. Yin, Z.; Chen, Y. L.; Kondreddi, R. R.; Chan, W. L.; Wang, G.; Ng, R. H.; Lim, J. Y.; Lee, W. Y.; Jeyaraj, D. A.; Niyomrattanakit, P.; Wen, D.; Chao, A.; Glickman, J. F.; Voshol, H.; Mueller, D.; Spanka, C.; Dressler, S.; Nilar, S.; Vasudevan, S. G.; Shi, P. Y.; Keller, T. H. J. Med. Chem. 2009, 52, 7934.

http://dx.doi.org/10.1021/jm901044z

PMid:20014868

198. Frechette, R. Annu. Rep. Med. Chem. 2007, 42, 360.

http://dx.doi.org/10.1016/S0065-7743(07)42022-X

199. Staab, H. A.; Bauer, H.; Schneider, K. M. "Azolides in Organic Synthesis and Biochemistry", Wiley-VCH, Weinheim, 2002.

PMCid:PMC128023

200. Elguero, J.; Foces-Foces, C.; Sanz, D.; Claramunt, R. M. "Azolides: Structural Aspects" in Advances in Nitrogen Heterocycles, 2000, 4, 295.

201. Acker, T. M.; Yuan, H.; Hansen, K. B.; Vance, K. M.; Ogden, K. K.; Jensen, H. S.; Burger, P. B.; Mullasseril, P.; Snyder, J. P.; Liotta, D. C.; Traynelis, S. F. Mol. Pharmacol. 2011, 80, 782.

http://dx.doi.org/10.1124/mol.111.073239

PMid:21807990 PMCid:PMC3198917

202. Ahn, J. H.; Kim, H.-M.; Jung, S. H.; Kang, S. K.; Kim, K. R.; Rhee, S. D.; Yang, S.-D.; Cheon, H. G.; Kim, S. S. Bioorg. Med. Chem. Lett. 2004, 14, 4461.

http://dx.doi.org/10.1016/j.bmcl.2004.06.046

PMid:15357972

203. Ahn, J. H.; Kim, J. A.; Kim, H.-M.; Kwon, H.-M.; Huh, S.-C.; Rhee, S. D.; Kim, K. R.; Yang, S.-D.; Park, S.-D.; Lee, J. M.; Kima, S. S.; Cheon, H. G. Bioorg. Med. Chem. Lett. 2005, 15, 1337.

http://dx.doi.org/10.1016/j.bmcl.2005.01.020

PMid:15713382

204. Meyers, M. J.; Arhancet, G. B.; Hockerman, S. L.; Chen, X.; Long, S. A.; Mahoney, M. W.; Rico, J. R.; Garland, D. J.; Blinn, J. R.; Collins, J. T.; Yang, S.; Huang, H.-C.; McGee, K. F.; Wendling, J. M.; Dietz, J. D.; Payne, M. A.; Homer, B. L.; Heron, M. I.; Reitz, D. B.; Hu, X. J. Med. Chem. 2010, 53, 5979.

http://dx.doi.org/10.1021/jm100505n

PMid:20672822 
205. Leftheris, K.; Zheng, Y.; Lala, D. S. Annu. Rep. Med. Chem. 2011, 46, 97. http://dx.doi.org/10.1016/B978-0-12-386009-5.00021-7

206. Barth, F. Annu. Rep. Med. Chem. 2005, 40, 106. http://dx.doi.org/10.1016/S0065-7743(05)40007-X

207. Lange, J. H. M.; Coolen, H. K. A. C.; Van Stuivenberg, H. H.; Dijksman, J. A. R.; Herremans, A. H. J.; Ronken, E.; Keizer, H. G.; Tipker, K.; McCreary, A. C.; Veerman, W.; Wals, H. C.; Stork, B.; Verneer, P. C.; Den Hartog, A. P.; De Jong, N. M. J.; Adolfs, T. J. P.; Hoogendoorn, J.; Kruse, C. G. J. Med. Chem. 2004, 47, 627.

http://dx.doi.org/10.1021/jm031019q

PMid:14736243

208. Van Gaal, L. F.; Rissanen, A. M.; Scheen, A. J.; Ziegler, O.; Rossner, S. Lancet, 2005, 365, 1389.

http://dx.doi.org/10.1016/S0140-6736(05)66374-X

209. Wood, K. W.; Bergnes, G. Annu. Rep. Med. Chem. 2004, 39, 179.

http://dx.doi.org/10.1016/S0065-7743(04)39014-7

210. Cox, C. D.; Breslin, M. J.; Mariano, B. J.; Coleman, P. J.; Buser, C. A.; Walsh, E. S.; Hamilton, K.; Huber, H. E.; Kohl, N. E.; Torrent, M.; Yan, Y.; Kuo, L. C.; Hartman, G. D. Bioorg. Med. Chem. Lett. 2005, 15, 2041.

http://dx.doi.org/10.1016/j.bmcl.2005.02.055

PMid:15808464

211. Fraley, M. E.; Garbaccio, R. M.; Arrington, K. L.; Hoffman,W. F.; Tasber, E. S.; Coleman, P. J.; Buser, C. A.; Walsh, E. S.; Hamilton, K.; Fernandes, C.; Schaber, M. D.; Lobell, R. B.; Tao, W.; South, V. J.; Yan, Y.; Kuo, L. C.; Prueksaritanont, T.; Shu, C.; Torrent, M.; Heimbrook, D. C.; Kohl, N. E.; Huber, H. E.; Hartman, G. D. Bioorg. Med. Chem. Lett. 2006, 16, 1775.

http://dx.doi.org/10.1016/j.bmcl.2006.01.030

PMid:16439123

212. Tao, W.; South, V. J.; Zhang, Y.; Davide, J. P.; Farrell, L.; Kohl, N. E.; Sepp-Lorenzino, L.; Lobell, R. B. Cancer Cell 2005, 8, 49.

http://dx.doi.org/10.1016/i.ccr.2005.06.003

PMid:16023598

213. Garbaccio, R. M.; Fraley, M. E.; Tasber, E. S.; Olson, C. M.; Hoffman, W. F.; Arrington, K. L.; Torent, M.; Buser, C. A.; Walsh, E. S.; Hamilton, K.; Schaber, M. D.; Fernandes, C.; Lobell, R. B.; Tao, W.; South, V. J.; Yan, Y.; Kuo, L. C.; Prueksaritanont, T.; Slaughter, D. E.; Shu, C.; Heimbrook, D. C.; Kohl, N. E.; Huber, H. E.; Hartman, G. D. Bioorg. Med. Chem. Lett. 2006, 16, 1780.

http://dx.doi.org/10.1016/j.bmcl.2005.12.094

PMid:16439122

214. Chen, X.; Wang, W. Annu. Rep. Med. Chem. 2003, 38, 343.

http://dx.doi.org/10.1016/S0065-7743(03)38033-9 
215. Black, W. C. Annu. Rep. Med. Chem. 2004, 39, 127 (corresponds to a whole chapter devoted to cyclooxygenase-2 inhibitors).

216. Mason, N. S.; Mathis, C. A. Annu. Rep. Med. Chem. 2005, 40, 61.

217. Friesen, R. W.; Riendeau, D. Annu. Rep. Med. Chem. 2005, 40, 203. http://dx.doi.org/10.1016/S0065-7743(05)40013-5

218. Pain: Gastrointestinal safety of Celecoxib, Nature Rev. Rheumatology, 2013, 9, 134. http://dx.doi.org/10.1038/nrrheum.2013.12

219. Capone, M. L.; Tacconelli, S.; Sciulli, M. G.; Patrignani, P. Int. J. Immunopathol. Pharmacol. 2003, 16, 49.

PMid:14552704

220. Li, J.; DeMello, K. M. L.; Cheng, H.; Sakya, S. M.; Bronk, B. S.; Rafka, R. J.; Jaynes, B. H.; Ziegler, C. B.; Kilroy, C.; Mann, D. W.; Nimz, E. L.; Lynch, M. P.; Haven, M. L.; Kolosko, N. L.; Minich, M. L.; Li, C.; Dutra, J. K.; Rast, B.; M. Crosson, R. M.; Morton, B. J.; Kirk, G. W.; Callaghan, K. M.; Koss, D. A.; Shavnya, A.; Lund, L. A.; Seibel, S. B.; Petras, C. F.; Silvia, A. Bioorg. Med. Chem. Lett. 2004, 14, 95.

http://dx.doi.org/10.1016/j.bmcl.2003.10.004

PMid:14684306

221. Pal, M.; Madan, M.; Padakanti, S.; Pattabiraman, V. R.; Kalleda, S.; Vanguri, A.; Mullangi, R.; Mamidi, N. V. S. R.; Casturi, S. R.; Malde, A.; Gopalakrishnan, B.; Yeleswarapu, K. R. J. Med. Chem. 2003, 46, 3975.

http://dx.doi.org/10.1021/jm020563g

PMid:12954051

222. Bouchet, P.; Coquelet, C.; Elguero, J. Bull. Soc. Chim. Fr. 1977, 171.

223. Claramunt, R. M.; Alkorta, I.; Elguero, J. Heterocycles 1999, 51, 355. http://dx.doi.org/10.3987/COM-98-8381

224. Kirk, K. L. Fluorinated Five-Membered Nitrogen-Containing Heterocycles, in Fluorinated Heterocyclic Compounds, Ed. A. Petrov, Wiley, Hoboken, NJ, 2009.

225. Gakh, A. A. Monofluorinated Heterocycles, in J. Iskra, Halogenated Heterocycles, Top. Heterocycl. Chem. 2012, 27, 33.

http://dx.doi.org/10.1007/7081_2011_58

226. Burger, K.; Hein, F.; Dengler, O.; Elguero, J. J. Fluor. Chem. 1982, 19, 437.

http://dx.doi.org/10.1016/S0022-1139(00)83156-5

http://dx.doi.org/10.1016/S0022-1139(00)83144-9

http://dx.doi.org/10.1016/S0022-1139(00)83154-1

227. Elguero, J.; Yranzo, G. I.; Laynez, J.; Jiménez, P.; Menéndez, M.; J. Catalán, J. de Paz, J. L. G.; Anvia, F.; Taft, R. W. J. Org. Chem. 1991, 56, 3942.

http://dx.doi.org/10.1021/jo00012a030

228. Pérez, J. D.; Yranzo, G. I.; de Paz, J. L. G.; Elguero, J. J. Fluor. Chem. 1993, 63, 271.

http://dx.doi.org/10.1016/S0022-1139(00)80571-0 
229. Hargittai, I.; Brunvoll, J.; Foces-Foces, C.; Llamas-Saiz, A. L.; Elguero, J. J. Mol. Struct. 1993, 291, 211.

http://dx.doi.org/10.1016/0022-2860(93)85046-W

230. Elguero, J.; Fruchier, A.; Jagerovic, N.; Werner, A. Org. Prep. Proc. Int. 1995, 27, 33.

http://dx.doi.org/10.1080/00304949509458178

231. Alkorta, I.; Elguero, J.; Donnadieu, B.; Etienne, M.; Jaffart, J.; Schagen, D.; Limbach, H.-H. New J. Chem. 1999, 23, 1231.

http://dx.doi.org/10.1039/a904537f

http://dx.doi.org/10.1039/a904292j

232. Foces-Foces, C.; Trofimenko, S.; López, C.; Santa María, M. D.; Claramunt, R. M.; Elguero, J. J. Mol. Struct. 2000, 526, 59.

http://dx.doi.org/10.1016/S0022-2860(00)00444-0

233. Singh, S. P.; Kumar, V.; Aggarwal, R.; Elguero, J. J. Heterocycl. Chem. 2006, 43, 1003.

http://dx.doi.org/10.1002/jhet.5570430636

http://dx.doi.org/10.1002/jhet.5570430428

http://dx.doi.org/10.1002/jhet.5570430313

http://dx.doi.org/10.1002/jhet.5570430634

234. Bonacorso, H. G.; Wastowski, A. D.; Zanatta, N.; Martins, M. A. P.; Naue, J. A. J. Fluor. Chem. 1998, 92, 23.

http://dx.doi.org/10.1016/S0022-1139(98)00242-5

235. Martins, M. A. P.; Zanatta, N.; Bonacorso, H. G.; Rosa, F. A.; Claramunt, R. M.; García, M. A.; Santa María, M. D.; Elguero, J. Arkivoc 2006, iv, 29.

http://dx.doi.org/10.3998/ark.5550190.0007.404

236. Martins, M. A. P.; Pereira, C. M. P.; Moura, S.; Frizzo, C. P.; Beck, P.; Zanatta, N.; Bonacorso, H. G.; Flores, A. F. C. J. Heterocycl. Chem. 2007, 44, 1195.

http://dx.doi.org/10.1002/jhet.5570440537

237. Frizzo, C. P.; Moreira, D. N.; Guarda, E. A.; Fiss, G. F.; Marzari, M. R. B.; Zanatta, N.; Bonacorso, H. G.; Martins, M. A. P. Catal. Commun. 2009, 10, 1153.

http://dx.doi.org/10.1016/i.catcom.2009.07.005

http://dx.doi.org/10.1016/i.catcom.2008.12.030

238. Bonacorso, H. G.; Porte, L. M. F.; Cechinel, C. A.; Paim, G. R.; Deon, E. D.; Martins, M. A. P. Tetrahedron Lett. 2009, 50, 1392.

http://dx.doi.org/10.1016/j.tetlet.2009.01.005

239. Buriol, L.; Frizzo, C. P.; Marzari, M. R. B.; Moreira, D. N.; Prola, L. D. T.; Zanatta, N.; Bonacorso, H. G.; Martins, M. A. P. J. Braz. Chem. Soc. 2010, 21, 1037.

http://dx.doi.org/10.1590/S0103-50532010000600012

240. Martins, M. A. P.; Marzari, M. R. B.; Frizzo, C. P.; Zanatta, M.; Buriol, L.; Andrade, V.

P.; Zanatta, N.; Bonacorso, H. G. Eur. J. Org. Chem. 2012, 36, 7112.

http://dx.doi.org/10.1002/ejoc.201201111

241. Elguero, J. An. Quím. 2005, 101, 31. 


\section{Authors' Biographies}

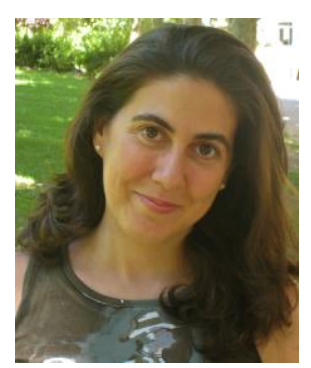

Ruth Pérez-Fernández received her European $\mathrm{PhD}$ degree in chemical sciences (UAM) in 2005. She has worked as a postdoctoral researcher at the University of Cambridge, CNIO and IQM-CSIC. In 2009 she was appointed to a permanent position in the Medicinal Chemistry Institute (CSIC). Currently, her research interests include PPAR ligands to treat metabolic syndrome (obesity and diabetes), ionic liquids and new analgesic drugs.

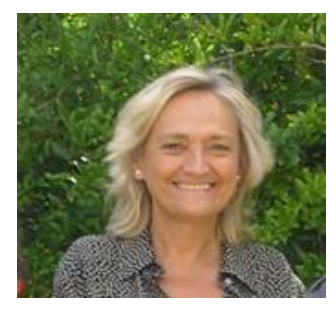

Pilar Goya Laza received her PhD in Chemistry from the Universidad Complutense, Madrid, and had a postdoctoral stay with Wolfgang Pfleiderer in Konstanz, Germany. She is research professor at the Instituto de Quimica Médica, CSIC, of which she was Director from 2005 to 2011. Her current research interests are focused on cannabinoids and PPAR ligands targeting the CNS and metabolic syndrome.

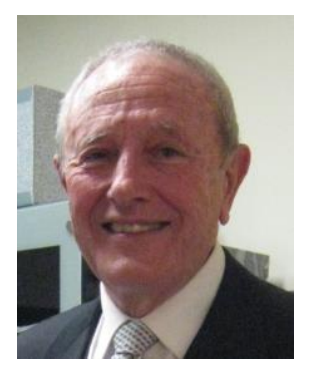

José Elguero was born in Madrid (Spain) in 1934 and received his $\mathrm{PhD}$ degree from the University of Montpellier (France) in 1961. He has worked in both the French CNRS and the Spanish CSIC where he is now Senior Research Scientist. He has been awarded the Gold Medal of the Spanish Royal Society of Chemistry, the Schutzenberg, Solvay and Ramón y Cajal Prizes. His specialties are heterocyclic chemistry and physical organic chemistry, fields in which he has published over 1500 papers. 